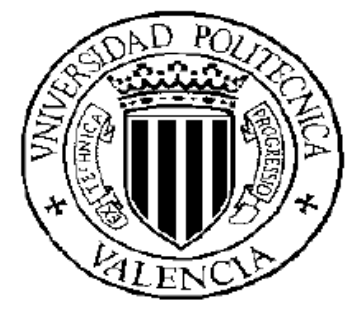

INSTITUTO DE AGROQUÍMICA Y TECNOLOGÍA DE ALIMENTOS

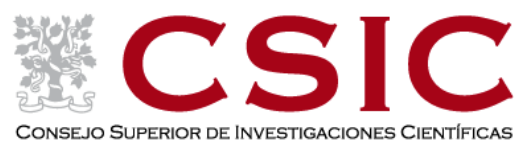

\title{
INFLUENCIA DE LAS CARACTERÍSTICAS SENSORIALES Y LA INFORMACIÓN NUTRICIONAL EN LA RESPUESTA DE LOS CONSUMIDORES A ALIMENTOS FUNCIONALES
}

TESIS DOCTORAL

Presentado por:

Patricia Arcia Cabrera

Directores:

Dra. Amparo Tárrega Guillem Dra. Elvira Costell Ibáñez Valencia, Setiembre 2012 

Da Elvira Costell lbáñez, Profesora de Investigación del Instituto de Agroquímica y Tecnología de Alimentos del Consejo Superior de Investigaciones Científicas

\section{y}

D. Amparo Tárrega Guillem, Investigadora del Instituto de Agroquímica y Tecnología de Alimentos del Consejo Superior de Investigaciones Científicas

\section{HACEN CONSTAR:}

que la memoria titulada "Influencia de las características sensoriales y la información nutricional en la respuesta de los consumidores a alimentos funcionales" que presenta Da Patricia Arcia Cabrera para optar al grado de Doctor por la Universidad Politécnica de Valencia, ha sido realizada bajo su dirección en el Instituto de Agroquímica y Tecnología de Alimentos (CSIC) y que reúne las condiciones para ser defendida por su autora.

Valencia, 3 de septiembre 2012

Fdo: Dra. Elvira Costell Ibañez

Fdo. Dra. Amparo Tarrega Guillem 

Esta tesis fue posible gracias al apoyo y subvención de varias instituciones y a muchas personas que de alguna forma colaboraron y acompañaron en este proceso.

La tesis se llevó a cabo en el Laboratorio de Propiedades Físicas del Instituto de Agroquímica y Tecnología de Alimentos (IATA-SCIC) de Valencia-España y en el Laboratorio Tecnológico del Uruguay (LATU), desde el 2009 al 2012.

Agradezco al LATU por darme la oportunidad de realizar este estudio y por el apoyo tanto económico como logístico brindado.

Agradezco al IATA-CSIC por permitirme realizar parte del trabajo experimental en sus instalaciones y por contar con la Dra. Elvira Costell Ibañez y la Dra. Amparo Tárrega Guillem como directoras.

Agradezco a Elvira Costell por poder realizar la tesis con ella, por enseñarme y por confiar en mí, permitiendo que realizara parte del trabajo experimental en mi país.

Agradezco especialmente a Amparo Tárrega por guiarme, transmitirme sus conocimientos y motivarme a continuar.

También quiero agradecer a mi colega, compañera y amiga, Ana Curutchet por estar a mi lado en todo este proceso.

Gracias al Departamento de Análisis de Productos Agropecuarios del LATU y a Facultad de Ingeniería de la Universidad de la República Oriental del Uruguay, por poder usar parte de sus instalaciones en la ejecución del trabajo experimental.

Un especial reconocimiento a los integrantes del panel de quesos, que no se cansaron de probar tantas muestras.

Al Dr. Luis Izquierdo por su apoyo en la realización de estudios estadísticos.

A la Dra. Inmaculada Carbonell por colaborar en las evaluaciones sensoriales en la sala de catas del IATA.

A mis amigos y compañeros de trabajo, de Uruguay y de España, que de forma incondicional colaboraron probando tantas muestras y completando largas encuestas. 
Quiero agradecer a mi familia por el apoyo constante durante todos estos años y principalmente a mi madre y a mi padre por haberme motivado y empujado a lanzarme en este camino.

$Y$ por supuesto a Jorge, quien me contuvo y sostuvo en todo momento. Gracias por ayudarme a continuar en los momentos de cansancio.

Gracias a todos por el apoyo, por acompañarme, por creer en mí y por permitirme ser quien soy. Esto no hubiera sido posible sin todos ustedes.

Valencia, Octubre 2012

Patricia Arcia 


\section{RESUMEN}

La investigación realizada en esta tesis se ha centrado en el estudio de los factores que afectan a la aceptabilidad de productos con características nutricionales especiales y en el desarrollo y optimización de un postre lácteo de bajo contenido en grasa y con características prebióticas.

En primer lugar se estudió y analizó la opinión de los consumidores uruguayos acerca de quesos con diferentes características funcionales. Utilizando la técnica de análisis conjunto se determinó el valor que los consumidores daban a distintas características del producto como el bajo contenido en grasa o en sal, ser probiótico o enriquecido en fibra y ser de elaboración industrial o artesanal. Para los dos productos estudiados, queso para untar y queso Dambo, el interés de los consumidores dependió principalmente del posible beneficio para la salud de cada uno de ellos y en menor medida, del tipo de elaboración. En general, los consumidores se mostraron más interesados en el queso con composición habitual que en los quesos con alguna característica funcional. Sin embargo, un grupo importante de consumidores (alrededor del 40\%) se mostraron tan interesados en ciertos quesos funcionales como en el queso normal. Entre las opciones consideradas, la reducción en el contenido en grasa fue la más interesante para los consumidores. Las causas del interés o desinterés de los consumidores por quesos con características funcionales se estudiaron con la técnica de escalamiento o "laddering". En general, los motivos mas importantes que mencionaron los consumidores para comprar un queso funcional fueron el mejorar su calidad de vida o su imagen física. Por otro lado, las dudas sobre posibles deficiencias en su calidad sensorial y la desconfianza en el efecto saludable real del producto, fueron los principales motivos que los consumidores alegaron para no comprar queso con alguna característica funcional.

En segundo lugar se estudiaron los factores que influyen en la aceptación de un producto funcional ya comercializado: El queso con bajo contenido en grasa 
("queso magro") de Uruguay. Para ello se analizaron seis muestras comerciales, representativas de la variación del este producto en el mercado uruguayo. Se estudió la relación entre las características sensoriales de las muestras, evaluadas por un panel de jueces entrenado y su aceptabilidad por consumidores. De acuerdo con el perfil sensorial obtenido, el queso magro uruguayo se caracterizó por presentar un olor y un sabor suaves, ser de firmeza intermedia, con una elasticidad media-alta y ser poco friable. Las mayores diferencias entre los quesos analizados se detectaron en la textura, principalmente en la firmeza y en la elasticidad, mientras que las diferencias percibidas en la intensidad de los atributos de sabor no fueron de mucha entidad. A pesar de ello, las diferencias perceptibles en la intensidad de algunos atributos de sabor, fueron las que más influyeron en la aceptabilidad de las muestras. Además de la influencia de los atributos sensoriales, se estudió también el posible efecto que las características de la etiqueta podían tener en la aceptabilidad final de las muestras. Las expectativas generadas por las distintas etiquetas en los consumidores fueron diferentes. Los motivos principales de los consumidores para elegir un queso fueron la confianza que inspiraban ciertas marcas o la creencia de que su producto sería de buena calidad sensorial en base al aspecto y diseño de la etiqueta.

Finalmente, para diseñar y optimizar la formulación de un nuevo postre prebiótico se estudió el efecto de la inulina en las propiedades físicas y sensoriales y en la aceptabilidad del producto. En primer lugar, se observó que en los postres enriquecidos con inulina de cadena larga se producía durante el almacenamiento la formación de cristales de inulina de tamaño heterogéneo que eran responsables de un aumento en la viscosidad y elasticidad del producto pero también, daban lugar a una sensación de arenosidad no deseable. Se observó que la inoculación de una pequeña cantidad de inulina tras la elaboración del producto (técnica de sembrado) era efectiva para obtener postres lácteos bajos en grasa y con un tamaño regular de partículas de inulina cuya abundancia y tamaño dependió de la concentración de inulina utilizada. En base a esto, se decidió 
desarrollar un nuevo postre prebiótico, de bajo contenido en grasa utilizando una mezcla de inulinas de cadena larga y de cadena corta. Se estudió la variación de las propiedades reológicas, sensoriales y de la aceptabilidad del producto en función de la concentración de la mezcla de inulinas, de azúcar y de aroma a limón, utilizando el Método de Superficie de Respuesta. Como era de esperar, la consistencia y la elasticidad del producto aumentaron con la concentración de la mezcla de inulinas y en menor medida, con la de azúcar. Mediante la utilización de las escalas para medir la adecuación de la intensidad de los atributos sensoriales (escalas JAR), se determinó el nivel de consistencia que los consumidores consideraban como el más adecuado para el producto. De los parámetros reológicos, el índice de consistencia y el módulo de elasticidad se relacionaron bien con la consistencia percibida y pueden ser buenos índices para predecir la adecuación de la consistencia de este tipo de postres lácteos.

Para optimizar la aceptabilidad del nuevo postre lácteo se estudió la relación entre las variaciones en la composición y la variación en la aceptabilidad. El nivel de agrado de los consumidores varió principalmente con la concentración de inulina y de azúcar y en menor medida, con la de aroma a limón. De acuerdo al modelo obtenido se determinó para cada ingrediente el intervalo de concentraciones de máxima aceptabilidad (entre 4 y 6,5\% de inulina, entre 9 y $12 \%$ de azúcar y entre 25 y 95 ppm de aroma de limón). Para validar el nuevo postre prebiótico se seleccionó una formulación (5.5\% inulina, 10\% de azúcar y 60 ppm de aroma) y se comparó con un postre de referencia elaborado sin inulina y con el contenido en grasa y en azúcar habituales. Con la adición de la mezcla de inulina de cadena corta y larga, además de la reducción del contenido en grasa se consiguió reducir el contenido en azúcar (12\% menos) y el de aroma de limón (60\% menos) comparado con el postre de referencia sin que se viera afectado el grado de aceptabilidad del producto por los consumidores. 



\section{RESUM}

La investigació realitzada en aquesta tesi s'ha centrat en l'estudi dels factors que afecten a l'acceptabilitat de productes amb característiques nutricionals especials i en el desenvolupament $\mathrm{i}$ optimització d'un producte lacti de baix contingut en greix i amb característiques prebióticques.

En primer lloc es va estudiar i va analitzar l'opinió dels consumidors uruguaians de formatges amb diferents característiques funcionals. Utilitzant la tècnica d'anàlisi conjunt es va determinar el valor que els consumidors donaven a distintes característiques del producte com el baix contingut en greix o en sal, ser probiótic o enriquit en fibra i ésser d'elaboració industrial o artesanal. Per als dos productes estudiats, formatge per untar i formatge Dambo, l'interès dels consumidors va dependre principalment del possible benefici per a la salut de cada un d'ells i en menor mesura, del tipus d'elaboració. En general, els consumidors es van mostrar més interessats en el formatge amb composició habitual que en els formatges amb alguna característica funcional. Tanmateix, un grup important de consumidors (al voltant del 40\%) es van mostrar tan interessats en certs formatges funcionals com en el formatge normal. Entre les opcions considerades, la reducció en el contingut en greix va ser l'opció més interessant per als consumidors. Les causes de l'interès o desinterès dels consumidors per formatges amb característiques funcionals es van estudiar amb la tècnica d'escalament o "laddering". En general, els motius més importants que van mencionar els consumidors per comprar un formatge funcional van ser el millorar la seua qualitat de vida o la seua imatge física. D'altra banda, els dubtes sobre possibles deficiències en la seua qualitat sensorial i la desconfiança en l'efecte saludable real del producte, van ser els principals motius que els consumidors van al·legar per a no comprar formatge amb alguna característica funcional. 
En segon lloc es van estudiar els factors que afecten l'acceptació d'un producte funcional ja comercialitzat: el formatge amb baix contingut en greix ("queso magro") d'Uruguai. Amb aquesta finalitat es van analitzar sis mostres comercials, representatives de la variació de l'aquest producte al mercat uruguaià. Es va estudiar la relació entre les característiques sensorials de les mostres, avaluades per un panell de jutges entrenat i la seua acceptabilitat per consumidors. D'acord amb el perfil sensorial obtingut, el formatge magre uruguaià es va caracteritzar per presentar una olor $\mathrm{i}$ un sabor suaus, ésser de fermesa intermèdia, amb una elasticitat mitjana-alta i ser poc friable. Les diferències més importants entre els formatges analitzats es van detectar en la textura, principalment en la fermesa $i$ en l'elasticitat, mentre que les diferències en la intensitat dels atributs de sabor no van ser de molt importants. A pesar d'això, les diferències en la intensitat d'alguns atributs de sabor, van ser les que però van influenciar en l'acceptabilitat de les mostres. A més a més de la influència dels atributs sensorials, es va estudiar també el possible efecte que les característiques de l'etiqueta podien tenir en l'acceptabilitat final de les mostres. Les expectatives generades per les distintes etiquetes en els consumidors van ser diferents. Els motius principals dels consumidors per elegir un formatge van ser la confiança que inspiraven certes marques o la creença que el seu producte era de bona qualitat sensorial en base a l'aspecte i disseny de l'etiqueta.

Finalment, per dissenyar i optimitzar la formulació d'un nou postre prebiótic es va estudiar l'efecte de l'inulina en les propietats físiques i sensorials $\mathrm{i}$ en l'acceptabilitat del producte. En primer lloc, es va observar que en els postres enriquits amb inulina de cadena llarga es produïa durant l'emmagatzematge la formació de cristals d'inulina de mida heterogènia que eren responsables d'un augment en la viscositat i elasticitat del producte però també, donaven lloc a una sensació arenosa no desitjable. Es va observar que la inoculació d'una petita quantitat d'inulina després de l'elaboració del producte (tècnica de sembrat) era efectiva per obtenir postres lactis baixos en greix i amb una mida regular de partícules d'inulina del qual abundància i mida va dependre de la concentració 
d'inulina utilitzada. En base a això, es va decidir desenvolupar un nou postre prebiótic, de baix contingut en greix utilitzant una mescla d'inulines de cadena llarga i de cadena curta. Es va estudiar la variació de les propietats reológicas, sensorials i de l'acceptabilitat del producte en funció de la concentració de la mescla d'inulinas, de sucre i d'aroma a llima, utilitzant el Mètode de Superfície de Resposta. Com era d'esperar, la consistència i l'elasticitat del producte van augmentar amb la concentració de la mescla d'inulines i en menor mesura, amb la de sucre. Mitjançant la utilització de les escales per mesurar l'adequació de la intensitat dels atributs sensorials (escales JAR), es va determinar el nivell de consistència que els consumidors consideraven com al més adequat per al producte. Dels paràmetres reológics, l'índex de consistència i el mòdul d'elasticitat es van relacionar bé amb la consistència percebuda i poden ser bons índexs per predir l'adequació de la consistència d'aquest tipus de postres lactis.

Per optimitzar l'acceptabilitat del nou postre lacti es va estudiar la relació entre les variacions en la composició i la variació en l'acceptabilitat. L'acceptabilitat del postre pels consumidors va variar principalment amb la concentració d'inulina i de sucre i en menor mesura, amb la d'aroma a llima. D'acord al model obtingut es va determinar per a cada ingredient l'interval de concentracions de màxima acceptabilitat (entre 4 i 6,5\% d'inulina, entre 9 i 12\% de sucre i entre 25 i 95 ppm d'aroma de llima). Per validar el nou postres prebiótico se va seleccionar una formulació ( $5.5 \%$ inulina, $10 \%$ de sucre i 60 ppm d'aroma) i es va comparar amb un postres de referència elaborat sense inulina $i \mathrm{amb}$ el contingut en greix $i$ en sucre habituals. Amb l'addició de la mescla d'inulina de cadena curta i llarga, a més a més de la reducció del contingut en greix es va aconseguir reduir el contingut en sucre (12\% menys) i el d'aroma de llima (60\% menys) comparat amb el postres de referència sense que es vera afectat el grau d'acceptabilitat del producte pels consumidors. 



\section{SUMMARY}

The research of this thesis focused on the study of factors affecting food functional products acceptance and the development and optimization of a probiotic low-fat dairy dessert.

First, the opinion of Uruguayan consumer about cheeses with different functional characteristics was studied and analysed. Conjoint analysis was used to determine the value that consumers gave to different product characteristics such as: low-fat, salt-reduced, to be probiotic, fiber-enriched, and the type of processing, as industrial or traditional. Spreadable cheese and Dambo cheese were the two products studied. Consumer interest mainly depended on the possible health benefit of each one, and to a lesser extent, in the type of processing. In general, consumers were more interested in the regular cheese than in the functional one. However, an important group of consumers (around 40\%) were as interested in certain functional cheeses as in the regular one. Among the different options, consumers considered the reduction in fat content as the most interesting. Laddering technique was used to study the reasons for acceptance or rejection of functional cheeses. In general, the main reasons mentioned by consumers to buy a functional cheese were to get a better quality of life or look more attractive. On the other hand, doubts about possible deficiencies in sensory quality and the distrust in the actual effect of the product on health, were the main reasons of consumers for not buying cheese with a functional benefits.

Secondly, the factors affecting the acceptance of a functional product just in the market, the low-fat cheese ("queso magro") of Uruguay were studied. The relationship between the sensory characteristics of six commercial samples, evaluated by a trained panel and their acceptance by consumers was determined. According to the sensory profile, Uruguayan low-fat cheeses were characterized by having a soft odor and taste, intermediate firmness, medium-high elasticity and low friability. Samples mainly differed in their texture attributes, firmness 
and elasticity though slight variations were observed for flavor attributes. However, flavor attributes like odor, taste intensity, bitterness and aftertaste were those that dictated the differences in acceptance. Besides the influence of the sensory attributes, the potential effect of label characteristics on the acceptance of samples was also studied. Consumer's expectations generated by several labels were different. The main reasons influencing the final decisions on purchasing Uruguayan low-fat cheese were the trust in certain brands or the expected pleasure based on the previous knowledge of the product or the label design.

Finally, to design and optimize the formulation of a new prebiotic dairy product, the effect of inulin on physical and sensory properties and product acceptance was studied. It was observed that during the storage of inulin-enriched dairy products, long-chain inulin formed a particulate gel of heterogeneous-size crystals that increased viscosity and elasticity of dairy products, but was also responsible for a rough sensation. It was observed that the inoculation of a small amount of inulin after producing the product (seeding technique) was effective to obtain regular size inulin particles for low-fat dairy desserts. The abundance and size of the inulin particles depended on the concentration of inulin used. In this way, it was decided to develop a prebiotic and low-fat dairy dessert, using a mixture of long and short chain inulin. Response Methodology Surface was used to study the variation of rheological properties and sensory product acceptance in response to the concentration of inulin, sugar and lemon flavor. As expected, the consistency and elasticity of the product increased with the concentration of inulin and to a lesser extent, with sugar. Using scales for measuring the suitability of the intensity of sensory attributes (Just About Right, JAR scales), the level of consistency that consumers considered as adequate for the product was established. From rheological parameters, consistency index and elasticity modulus were well correlated with perceived consistency showing to be good indexes to predict the suitability of the consistency of this type of dairy products. 
To optimize the acceptance of the new dairy dessert the relationship between variations in composition and variation in the acceptability was studied. The level of consumer acceptance mainly varied with the concentration of inulin and sugar, and to a lesser extent with lemon flavor. According to the model obtained, the range of concentration of each ingredient for the maximum acceptability was determined (between 4 and $6.5 \%$ for inulin, between 9 and 12\% for sugar and between 25 and $95 \mathrm{ppm}$ for lemon flavor). To validate the new dessert, the acceptance of the product with the formulation selected (5.5\% inulin, 10\% sugar and $60 \mathrm{ppm}$ of flavor) was compared with the acceptance of a reference dairy dessert made with regular fat and sugar content, without inulin addition. Results shown that the addition of the mixture of short and long chain inulin, besides the reduction in the amount of fat, also contained less sugar (12\% reduction) and less lemon flavor ( $60 \%$ reduction) than the reference product (regular fat content), without its acceptability being affected. 



\section{ÍNDICE GENERAL}

INTRODUCCIÓN GENERAL .....................................

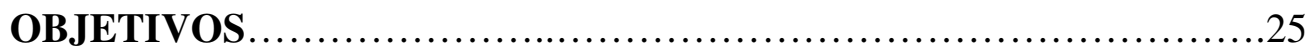

PRESENTACIÓN DE LOS TRABAJOS .............................29

CAPÍTULO 1. Response of Uruguayan consumers to cheeses with health benefits.............................................................

INTRODUCTION ............................................

MATERIALS AND METHODS .................................. 38

Conjoint study ............................................ 38

Soft laddering ............................................ 40

Data analysis.........................................42

RESULTS............................................43

Effect of health benefits and type of processing on consumers'

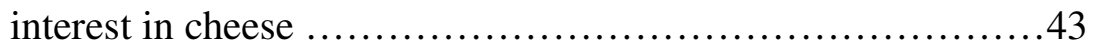

Consumer characteristics affecting response to cheeses with health benefits. .......................................50

Understanding how health benefits affect willingness to purchase cheese....................................................52

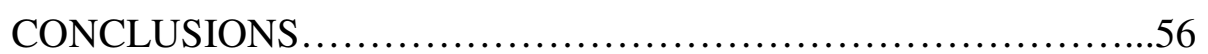

REFERENCES.................................................57

CAPÍTULO 2. Sensory properties and acceptance of Uruguayan low-fat

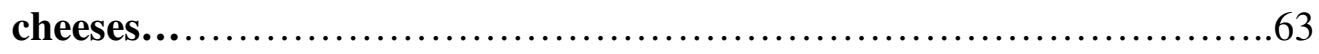

INTRODUCTION ...................................................... 66 
MATERIALS AND METHODS ................................67

Samples...............................................67

Chemical Analysis.......................................68

Instrumental Texture Analysis...........................68

Sensory analysis.....................................68

Data analysis................................................

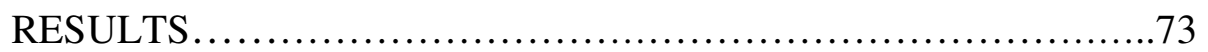

Cheese composition....................................73

Texture parameters....................................74

Panel performance...................................... 75

Sensory profile of cheeses...............................77

Relationship between acceptance and sensory properties......82

CONCLUSION .................................................. 83

REFERENCES...........................................84

CAPÍTULO 3. Influence of expectations created by label on consumers acceptance of Uruguayan low-fat cheeses............................... 89

INTRODUCTION ............................................92

MATERIALS AND METHODS ...................................94

Samples................................................94

Consumer acceptability.................................95

Soft laddering..........................................96

Data analysis.........................................97

RESULTS.................................................... 98

Expectations created by label and their effects on acceptability..98

Label characteristics affecting willingness to purchase.........101

CONCLUSION................................................. 107

REFERENCES................................................. 108 
CAPÍTULO 4. Effect of inulin seeding on rheology and microstructure of prebiotic dairy desserts....................................... 113

INTRODUCTION ............................................116

MATERIALS AND METHODS ................................117

Sample composition and preparation.....................117

Rheological measurements.............................118

Particle size distribution...................................119

Light microscopy....................................120

Statistical analysis...................................120

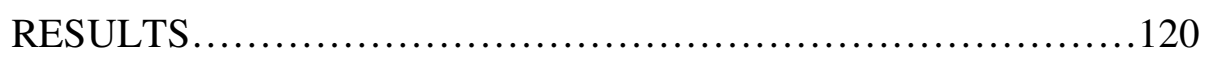

Rheological behavior.................................. 120

Microstructure.......................................127

CONCLUSION ...............................................134

REFERENCES........................................... 135

CAPÍTULO 5. Thickness suitability of prebiotic dairy desserts: Relationship with rheological properties...........................137

INTRODUCTION .......................................... 140

MATERIALS AND METHODS ...............................142

Sample composition and preparation........................142

Rheological measurements...............................144

Sensory evaluation...................................... 145

Data analysis..........................................147

RESULTS AND DISCUSSION................................ 148

Rheological properties. Effect of composition................148

Thickness suitability assessed by consumers. Effect of composition............................................154

Relationship between rheological properties and thickness

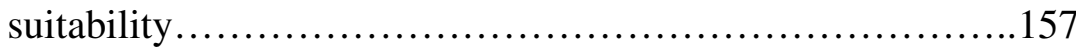


CONCLUSIONS............................................ 161

REFERENCES............................................... 162

CAPÍTULO 6. Inulin blend as prebiotic and fat replacer in dairy desserts: optimization by Response Surface Methodology...............167

INTRODUCTION ..........................................170

MATERIALS AND METHODS ...................................172

Materials.......................................... 172

Experimental design and sample preparation................172

Sensory evaluation...................................... 176

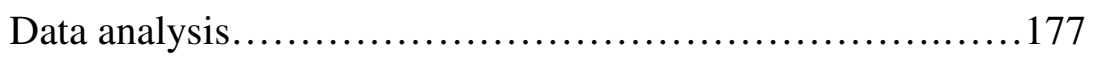

RESULTS AND DISCUSSION................................ 178

Acceptability of desserts with regular fat content: Reference sample optimization.................................. 178

Acceptability of low-fat desserts with inulin. Formulation optimization......................................... 182

Comparison between the prebiotic low-fat dairy dessert and the regular fat content dessert............................... 188

CONCLUSIONS ............................................. 190

REFERENCES.............................................190

RESUMEN DE RESULTADOS .................................... 195

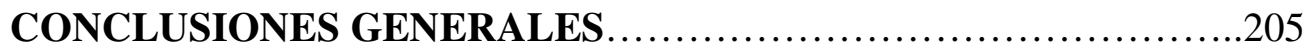




\section{INTRODUCCIÓN GENERAL}





\section{$\underline{\text { Alimentos funcionales }}$}

En los últimos tiempos, la demanda de los consumidores respecto a los alimentos en los países desarrollados ha ido cambiando considerablemente. Los consumidores concienciados de la influencia de la alimentación en su salud (Mollet y Rowland, 2002; Young, 2000), están cada vez más interesados en consumir alimentos que, además de satisfacer el apetito y proporcionar los nutrientes necesarios, ayuden a prevenir ciertas enfermedades o a incrementar su bienestar físico y mental (Menrad, 2003; Roberfroid, 2000). En este marco surge el concepto de alimento funcional como aquel que aporta algún beneficio para la salud adicional a su valor nutricional básico (Bech-Larsen y Grunert, 2003; Frewer et al., 2003; Prates y Mateus, 2002). Existe una amplia gama de definiciones para estos alimentos denominados funcionales (Kaur y Das, 2011), pero no hay una definición internacionalmente reconocida y aceptada. La Comunidad Europea, en el año 2000, definió alimento funcional como "un alimento natural o uno al que se le ha añadido o eliminado componentes, por vía tecnológica o biotecnológica, de forma que se ha demostrado satisfactoriamente que tiene un efecto beneficioso para la salud además de los efectos nutricionales habituales" (EUR 1859, 2000). En América Latina no existe una definición o legislación relativa a los alimentos funcionales. En Uruguay los alimentos funcionales se pueden incluir dentro de los denominados "alimentos modificados", que se definen como aquellos que están específicamente preparados para atender las necesidades especiales de cierto tipo de consumidores y se diferencian de los alimentos convencionales, debido al hecho de que su contenido de uno o más nutrientes han sido modificado (RBN, 1994)

Se han propuesto distintas clasificaciones de los alimentos funcionales atendiendo a diferentes criterios (Holm, 2003; Siró et al., 2008; Klimas et al., 2008; Saiz, 2011). Una de las más claras desde el punto de vista tecnológico es la 
que los clasifica en función del método o proceso utilizado para obtención del alimento funcional (Kaur y Das, 2011). Con este criterio se pueden establecer cuatro grupos: 1) Alimentos tradicionales a los que se ha modificado su formulación, ya sea por la incorporación o enriquecimiento en algún componente con efecto beneficioso sobre la salud (fibra, bífidus, vitaminas, minerales, omega-3, fitoesteroles) o por la eliminación o reducción del contenido de algún ingrediente que puede resultar perjudicial para la salud (grasa, sodio, azúcar); 2) Alimentos modificados mediante variaciones en los procesos de transformación (tratamiento térmico, fermentación, extrusión) para favorecer o incrementar la formación de compuestos con alguna actividad biológica específica o reducir la presencia de determinados compuestos con características anti-nutricionales (ácido fítico, inhibidores de tripsina) o perjudiciales para algunos consumidores (colesterol, lactosa); 3) Materias primas de origen animal cuya composición se ha modificado variando la alimentación del animal (huevos o carnes con alto contenido de ácidos grasos $\omega$-3, carne con alto contenido en ácido linoleico) o de origen vegetal por efecto de nuevos tratamientos post-cosecha (uvas con mayor capacidad antioxidante obtenidas mediante radiación ultravioleta) y 4) Nuevos alimentos obtenidos por manipulación genética o por selección de nuevas variedades como arroz con alto contenido de hierro o de vitamina B, aceites vegetales con una mejor composición de ácidos grasos, alimentos sin alérgenos, aceite de canola con altos niveles de carotenoides, trigo con una mejora en los niveles de luteína o frutos rojos con alto contenido de antioxidantes. De todos estos tipos de alimentos funcionales, los más habituales, en la mayoría de los mercados, son los alimentos cuya composición se ha modificado ya sea por incorporación de algún componente beneficioso o por la reducción o eliminación de algún componente perjudicial.

En los últimos años se ha desarrollado una importante labor de investigación para identificar componentes que presenten actividad fisiológica demostrada, por 
ejemplo, para mejorar el tránsito intestinal (Gibson y Roberfroid, 1995; Heredia et al., 2002; Beecher, 1999), el sistema inmunológico (Mercenier et al., 2002; Steed y Macfarlane, 2009) o para reducir el colesterol (Anderson et al., 1973), la glucemia (Albrink et al., 1979; Rivellese et al., 1980), la hipertensión arterial (Tuomilehto et al., 2001), o la obesidad (Tarakci y Kucukoner, 2006). Entre ellos, los ingredientes con carácter probiótico, prebiótico y con efecto fibra están principalmente relacionados con la mejora de la flora bacteriana y del tránsito intestinal. Los probióticos son microorganismos no patógenos, generalmente de las especies de Lactobacillus y Bifidobacterium, cuya ingesta puede mejorar el equilibrio y calidad de la flora bacteriana intestinal confiriendo ciertos beneficios al huésped al mejorar su salud o prevenir ciertas enfermedades (Fric, 2007; Sanders, 1998; Tannock, 1999). La fibra dietética incluye polisacáridos, oligosacáridos, lignina y sustancias vegetales que son resistentes a la digestión y absorción en el intestino delgado y que se fermentan completa o parcialmente en el intestino grueso. La fibra dietética contribuye a favorecer el tránsito intestinal y de forma indirecta, disminuye la incidencia de varios tipos de enfermedades (Burkitt 1975; Graham et al., 1978). Los ingredientes prebióticos se definen como aquellos que mejoran la composición y/o actividad de la microbiota intestinal y le confieren al huésped beneficios incrementando su bienestar y su salud (Roberfroid, 2007; Steed y Macfarlane, 2009). La inulina, el arabinoxilano y la oligofructosa, son algunos de los prebióticos más estudiados y utilizados (Gibson, 2004). Con respecto a la reducción en el contenido de ciertos componentes de los alimentos, el desarrollo de productos con bajo contenido en sodio o en grasa responde a las recomendaciones de las autoridades sanitarias de disminuir la ingesta de los mismos (WHO, 2003). En los países desarrollados el consumo excesivo de grasa y sodio constituye un problema de salud pública debido a su relación con el desarrollo de hipertensión arterial, enfermedades coronarias y obesidad (Law, 1997; Lichtenstein et al., 2006). 
En los últimos años la industria alimentaria ha dedicado parte importante de su investigación e innovación al área de los productos funcionales (Jones y Jew, 2007; Siró et al., 2008). En Europa, los países con mayor crecimiento en las ventas de alimentos funcionales han sido Alemania, Francia, Reino Unido y los Países Bajos (Jago, 2009), aunque en otros países, como España, también se observan tasas importantes de crecimiento. En los últimos años el interés de los consumidores europeos ha ido en aumento aunque a niveles inferiores a los observados en los EE.UU (Menrad, 2003; IFIC, 2007). La diferente predisposición de los consumidores de distintos países a consumir alimentos funcionales se puede explicar por sus diferencias culturales, hábitos y costumbres (van Trijp y van der Lans, 2007). Se estima que el consumo de alimentos funcionales en Europa podría llegar a alcanzar en la segunda década de este siglo una cuota de mercado cercana al 5\% de la de alimentos y bebidas (Menrad, 2003).

Sin embargo, hay que tener en cuenta que la visión que puede tener la industria respecto al interés de los consumidores por los alimentos funcionales podría no corresponder a una situación real. La preocupación en la salud no es el único factor que la gente tiene en cuenta a la hora de elegir y consumir sus alimentos (Mela, 2001). Tanto la incorporación de un compuesto funcional como la eliminación de algún ingrediente con efecto perjudicial, además de proporcionar un efecto beneficioso en la salud, modifica la composición y la estructura de los alimentos. Estas modificaciones pueden dar lugar a cambios en los atributos sensoriales perceptibles y afectar directamente la aceptabilidad del producto. La percepción de los posibles beneficios de un alimento funcional puede resultar un valor añadido para el consumidor, pero puede no ser suficiente para compensar una calidad sensorial deficiente (Siró et al., 2008). Además, la opinión que cada consumidor tiene sobre las características nutritivas o la composición de un producto (Bruhn et al., 1992), sobre su seguridad (Wilcock et al., 2004) e incluso, 
sobre su marca comercial (Guerrero et al., 2000) o su precio (Caporale et al., 2001) condicionan también su elección en el momento de la compra y pueden modificar el grado de placer del consumidor cuando lo ingiere.

\section{$\underline{\text { El papel del consumidor en el éxito de un alimento funcional }}$}

El conocimiento de cómo influyen los factores sensoriales y no sensoriales del producto en su elección y en su aceptación por los consumidores se considera hoy imprescindible para desarrollar un producto funcional con posibilidades de éxito en el mercado (Worsley y Skrzypiec, 1998; Ares y Gambaro, 2007; Steptoe et al., 1995). Básicamente, la respuesta final del consumidor frente a los alimentos está definida por las características sensoriales, nutricionales y comerciales del producto y por las características fisiológicas, psicológicas y sociológicas de los consumidores.

\section{Factores sensoriales}

Por lo general, los consumidores no están dispuestos a aceptar alimentos funcionales que presenten una calidad sensorial muy inferior a la de los alimentos convencionales (Hilliam, 2003; Tuorila y Cardello, 2002; Verbeke, 2006). Es poco probable que un alimento sea aceptado por los consumidores si no les gusta, a pesar de que sea beneficioso para su salud (Aikman et al., 2006; Cox et al., 2004; Verbeke, 2006). En ocasiones, la incorporación del nuevo ingrediente funcional (ácido graso omega-3, hierro, fibra, etc), da lugar a la aparición de sabores extraños o ajenos al producto (Tuorila y Cardello, 2002; Martini et al., 2009; Let et al., 2007). La incorporación de macromoléculas (hidrocoloides y proteínas) modifica la estructura del producto lo que suele causar cambios, favorables o no favorables, en la textura percibida (Dickinson, 2007; Purwanti et al., 2010; Slavin et al., 2000). La reducción de un ingrediente o 
componente del alimento puede ser crítico cuando éste es clave en la percepción de las características sensoriales. La disminución del contenido en sal provoca cambios drásticos en el sabor y en ciertos productos (quesos y elaborados cárnicos) puede producir importantes cambios en la textura (Mattes, 1997; Petridis, et al., 2010; Ruussunen y Poulanne, 2005). La cantidad de grasa es también clave en la percepción de ciertos atributos de textura como la cremosidad o untuosidad, de aspecto, como el brillo y tiene un papel fundamental en el sabor, no sólo por el aroma que aporta la propia grasa en determinados alimentos (ej. aroma de mantequilla), sino porque afecta a la intensidad y duración de otros sabores (Lucca y Tepper, 1994)

\section{Factores no-sensoriales}

Factores no sensoriales como la alegación nutricional, el precio, la marca o las características del envase influyen también en la aceptabilidad de los productos funcionales (Ares et al., 2009; Wills et al., 2012). En general, la información sobre los beneficios nutricionales específicos de un alimento le proporciona un valor añadido y puede incrementar el interés por adquirirlo y consumirlo (Sabbe et al., 2009; Mialon et al., 2002; Luckow et al., 2006; Behrens et al., 2007). La marca comercial es también un factor importante en la aceptación de un alimento (Ambler, 1997; Ambler et al., 2002; Dodds et al., 1991; O’Cass and Lim, 2001; Jaeger, 2006) ya que para el consumidor puede constituir un compromiso o garantía y un signo de calidad (Keller et al., 1998). En yogures con características funcionales, Ares et al. (2009) observaron un incremento en el interés de los consumidores por determinados productos cuando eran de una marca nacional conocida. Otro factor importante es el aspecto del envase (color o combinación de colores, diseño y la inclusión o no de determinadas imágenes) que puede jugar un rol importante en la percepción de los consumidores de productos funcionales (Ares et al., 2010). Sin embargo, en todos estos estudios, el factor predominante en la aceptación del producto fue su calidad sensorial. 


\section{Opinión, actitudes y expectativas del consumidor}

Además de las características propias del alimento y de las características fisiológicas de los consumidores, otros factores, relacionados con los mecanismos cognitivos y de percepción influyen en la decisión de cada consumidor a aceptar o rechazar un producto (Shepherd, 1989; Shepherd and Sparks, 1994). En el caso de los alimentos funcionales, es especialmente importante conocer cómo las expectativas, actitudes, opiniones y hábitos alimentarios del consumidor influyen en su aceptación. Las opiniones y creencias que el consumidor tiene sobre un determinado producto juegan un doble papel: influyen en la elección del alimento antes de consumirlo y en su posterior aceptación o rechazo después de su consumo. La respuesta del consumidor dependerá de que el producto satisfaga o no sus expectativas respecto al producto (Cardello, 1994). Desde el punto de vista práctico, la cuestión que se plantea es determinar cómo la confirmación o no confirmación de las expectativas afecta a la aceptación del alimento. El interés del consumidor en seguir una dieta saludable aumenta la probabilidad de compra de alimentos funcionales e incluso, puede aumentar su aceptabilidad (Villegas et al., 2008). Este interés puede estar condicionado por el estado de salud del consumidor y suele ser mayor en personas con problemas de salud propios o de los familiares cercanos (Verbeke, 2005). La familiaridad del consumidor con el ingrediente funcional incluido en el alimento puede condicionar su grado de aceptación (Villegas et al., 2008). Cuando el alimento incluye ingredientes funcionales que resultan familiares al consumidor, como vitaminas o minerales, normalmente es preferido a otro con ingredientes menos conocidos, como los polifenoles o los flavonoides (BechLarsen y Scholderer, 2007; Siró et al., 2008).

Es difícil estudiar y controlar simultáneamente todos los factores que pueden afectar la respuesta de los consumidores, tanto respecto a los diferentes tipos de alimentos funcionales que ya existen en el mercado como frente a los nuevos 
productos que, con distintas características nutricionales, pueden incrementar la oferta comercial. El problema reside en que la importancia relativa de cada uno de los factores citados varía en función de las características de cada alimento funcional y también, de la situación sociológica y cultural de los distintos grupos de consumidores.

\section{Factores que influyen en la respuesta del consumidor a quesos funcionales}

El queso es un producto bien aceptado y consumido en todo el mundo debido a sus propiedades nutricionales y sensoriales que lo hacen adecuado para personas de un amplio espectro de edades (Walter et al., 2008). Se han propuesto y estudiado diferentes tipos de quesos con distintas características funcionales, como quesos con efecto pro y/o prebiótico (Guttierres y Barreto, 2010; Araujo et al., 2010; Lima Alves, et al., 2008), bajos en grasa (Hennelly et al., 2006; Vithanage et al., 2008; Koca y Metin, 2003; Lteif et al., 2009) o bajos en sodio (Grummer et al., 2012; Cruz et al., 2011; El-Bakry et al., 2011; Ritvanen et al., 2010). En Uruguay, el queso es uno de los productos lácteos más consumidos y según las previsiones de la FAO, su consumo seguirá creciendo durante el periodo 2010-2019, (OCDE-FAO, 2010). Sin embargo, la presencia en el mercado uruguayo de quesos funcionales es escasa aunque, en principio, los consumidores uruguayos parecen estar dispuestos a consumir alimentos con un impacto positivo en su salud (Ares et al., 2008). Hasta hoy, no existe información sobre su interés en quesos con características funcionales. En esta situación, la primera cuestión interesante sería investigar que características nutricionales específicas de los quesos podrían resultar interesantes para los consumidores e identificar los motivos por los que estarían dispuestos a comprarlos y consumirlos. 
Una de las pocas excepciones de queso funcional en el mercado uruguayo es el que se conoce como "queso magro" que es una variedad de queso con un contenido en grasa reducido (10-25\%; RBN, 1994). Debido al aumento en la preocupación de los consumidores por la salud y por el sobrepeso, se ha incrementado su consumo y ello constituye una oportunidad para la industria quesera. Resulta por tanto interesante analizar las características del queso magro que influyen en su aceptación por los consumidores. No sólo es necesario conocer y caracterizar los atributos sensoriales determinantes de su aceptabilidad sensorial, sino que también es importante identificar las características de la etiqueta más apreciadas por los consumidores y cómo pueden éstas influir en la aceptabilidad final del producto. La etiqueta es uno de los componentes extrínsecos de un producto que el consumidor tiene en cuenta a la hora de comprar, ya que actúa como un medio para atraer su atención y proporcionarle información. Estudios anteriores han demostrado que las características del envase, y en especial las relacionadas con la etiqueta, pueden influir en las expectativas de los consumidores respecto al producto y en su aceptación o rechazo (Da Costa et al., 2000; Deliza et al., 2003; Rowan, 2000; Torres et al., 2012; Varela et al., 2010 Villegas et al., 2008). La etiqueta de un producto incluye la marca comercial, información sobre su composición, características nutricionales, identificación del fabricante y origen geográfico. Pero además, tiene un diseño gráfico y unas características estéticas determinadas. Todo ello puede afectar, positiva o negativamente la imagen global del producto y por tanto, generar diferentes expectativas en el consumidor. En el caso de los quesos bajos en grasa uruguayos, y con vistas a incrementar su éxito en el mercado, seria interesante, además de identificar las características sensoriales que mas influyen en su aceptabilidad, evaluar la incidencia de las expectativas creadas por la información y características de la etiqueta en la respuesta del consumidor. 


\section{Diseño y optimización de la calidad sensorial de un nuevo producto lácteo de carácter prebiótico}

En el diseño y desarrollo de un nuevo alimento funcional es necesario que el producto final tenga una calidad sensorial que satisfaga los requerimientos del consumidor. Por este motivo, el conocimiento de cómo influyen la composición y las interacciones entre ingredientes en las propiedades físicas y sensoriales y en la aceptabilidad del alimento constituye información muy valiosa para poder desarrollar con éxito un nuevo producto funcional.

La inulina es un polisacárido compuesto de unidades de fructosa, que se encuentra de forma natural en varias frutas y hortalizas. La inulina nativa, extraída directamente de la fuente vegetal, está formada por cadenas de fructosa con grado de polimerización muy variado (2-60 unidades), pero también hay en el mercado inulina con un grado de polimerización específico: inulina de cadena larga (>20 unidades) o inulina de cadena corta ( $<10$ unidades). La ingestión de inulina aporta no solo los beneficios inherentes a su condición de fibra dietética (reducción de los niveles de lípidos y de colesterol en la sangre, regulación del tránsito intestinal e incremento de la adsorción de calcio) (Flamm et al., 2001), sino también, los derivados de su carácter prebiótico como la estimulación del crecimiento de las bifidobacterias (Roberfroid et al., 1998; Roberfroid y Slavin, 2000) y la regulación de la flora intestinal del colon, disminuyendo el crecimiento de las bacterias de las clases Fusarium y Clostridium (Kaur y Grupta, 2002). Además de estos efectos beneficiosos para la salud, la inulina presenta propiedades tecnológicas interesantes que dependen del grado de polimerización de sus cadenas. La inulina de cadena corta tiene capacidad edulcorante por lo que se ha utilizado como sustituto parcial de la sacarosa, mientras que la inulina de cadena larga se comporta como un agente espesante y puede utilizarse como modificador de textura o como sustituto de grasa 
(Tungland y Meyer, 2002). Teniendo en cuenta estas características, surge la idea de utilizar mezclas de inulina de cadena corta y de cadena larga para desarrollar un postre lácteo que, además de tener carácter prebiótico, pueda tener un menor contenido en grasa y en azúcar.

La incorporación inulina de cadena larga produce cambios en la estructura de productos lácteos modificando tanto el comportamiento reológico como la textura percibida (Villegas et al, 2007). Esto se debe a que en presencia de agua la inulina forma un gel de partículas capaz de retener agua y aumentar la consistencia del producto. González-Tomás et al., (2010) observaron que la cremosidad y la consistencia de postres lácteos se incrementaba con la adición de inulina de cadena larga aunque también le confería una textura arenosa no deseable en este tipo de productos. Esta sensación de arenosidad ha sido atribuida a la presencia de cristales de inulina de tamaño superior a $10 \mu \mathrm{m}$ formados durante el almacenamiento del producto (Torres et al., 2010). En disoluciones acuosas de inulina se ha observado que la cinética de formación de cristales, su tamaño y las características del gel formado dependen de la concentración, de las condiciones termomecánicas de preparación (temperatura y agitación) y de la presencia de núcleos de cristalización que favorece la formación rápida de cristales de pequeño tamaño. Ello permite concluir que para poder desarrollar postres lácteos enriquecidos con inulina con características sensoriales aceptables por el consumidor es necesario controlar la distribución del tamaño de cristales formados. Por otra parte, se ha observado que el uso combinado de inulina de cadena larga y de cadena corta puede incrementar el aroma, el dulzor y la consistencia de postres lácteos aunque la magnitud de estos efectos depende de la composición de las muestras (Tárrega et al., 2010). Por todo ello, para el desarrollo de un nuevo postre lácteo que reúna un carácter prebiótico, un contenido en grasa reducido y un menor contenido en azúcar y tenga a la vez una características sensoriales que lo hagan apetecible para el consumidor es 
necesario conocer como la variación en la composición (concentración de inulina, de azúcar y de aroma) afecta a la percepción sensorial y a la aceptabilidad del producto por los consumidores.

\section{Bibliografía}

Aikman, S. N., Min, K. E., \& Graham, D. (2006). Food attitudes, eating behavior, and the information underlying food attitudes. Appetite, 47(1): 111-114.

Albrink, M. J., Newman, T., \& Davidson, P. C. (1979). Affect of high and low fibre diets on plasma lipids and insulin. American Journal of Clinical Nutrition, 32: 1486- 1496.

Ambler, T. (1997). How much of brand equity is explained by trust?. Management Decision, 35: 283-292.

Ambler, T., Bhattacharya, C. B., Edell, J., Keller, K. L., Lemon, K. N. \& Mittal, V. (2002). Relating Branding and Customer Perspectives on Marketing Management. Journal of Service Research 5(1): 13-25.

Anderson, J., Grande, F. \& Keys, A. (1973). Cholesterol lowering diets: experimental trials and literature reviews. Journal of the American Dietetic Association 62(2): 133-142.

Araujo, E. A., Carvalho, A. F. de, Leandro, E. S., Furtado, M. M., \& Moraes, C. A. (2010). Development of a symbiotic cottage cheese added with Lactobacillus delbrueckii UFV H2b20 and inulin. Journal of Functional Foods, 2: 85-89

Ares, G., Besio, M., Giménez, A. \& Deliza, R. (2010). Relationship between involvement and functional milk desserts intention to purchase. Influence on attitude towards packaging characteristics. Appetite, 55(2): 298-304. 
Ares, G. \& Gámbaro, A. (2007). Influence of gender, age and motives underlying food choice on perceived healthiness and willingness to try functional foods. Appetite, 49: 148-158.

Ares, G., Giménez, A. \& Deliza, R. 2010. Influence of three non-sensory factors on consumer choice of functional yogurts over regular ones. Food Quality and Preference, 21: 361-367.

Ares, G., Giménez, A. \& Gámbaro, A. 2008. Influence of nutritional knowledge on perceived healthiness and willingness to try functional foods. Appetite, 51: 663-668.

Bech-Larsen, T., \& Grunert, K. G. (2003). The perceived healthiness of functional foods - A conjoint study of Danish, Finnish and American consumers' perception of functional foods. Appetite, 40: 9-14.

Bech-Larsen, T., \& Scholderer, J. (2007). Functional foods in Europe: Consumer research, market experiences and regulatory aspects. Trends in Food Science and Technology, 18: 231-234.

Beecher, G. R. (1999). Phytonutrients role in metabolism: effects on resistance to degenerative processes. Nutrition Reviews, 57: 3-6.

Behrens, J. H., Villanueva, N., \& da Silva, M. A. A. P. (2007). Effect of nutrition and health claims on the acceptability of soya milk beverages. International Journal of Food Science and Technology, 42: 50-56.

Bruhn, C.M., Cotter, A., Diaz-Knauf, K., Sutherlin, J., West, E., Wightman, N., Williamson, E., \& Yaffee, M. (1992). Consumer attitudes and market potential for foods using fat substitutes. Journal Dairy Science, 75: 25692577.

Burkitt, D. P. (1975). Large-bowel cancer: an epidemiological jigsaw puzzle. Journal of the National Cancer Insitute, 54(1): 3-6.

Caporale, G., \& Monteleone, E. (2001). Effect of expectations induced by information on origin and its guarantee on the acceptability of a traditional food: olive oil. Sciences des Aliments, 21: 243-254. 
Cardello, A.V.A. (1994). Consumer expectations and their role in food acceptance. In: Measurement of Food Preferences. HJH MacFie and DMH Thomson (Eds.). pp 253-297. Blackie Academic and Professional, London.

Cox, D. N., Koster, A., \& Russell, C. G. (2004). Predicting intentions to consume functional foods and supplements to offset memory loss using an adaptation of protection motivation theory. Appetite, 33: 55-64.

Cruz, A. G., Faria, J. A. F., Pollonio, M. A. R., Bolini, H. M. A., Celeghini, R. M. S., Granato, D., \& Shah, N. P. (2011). Cheeses with reduced sodium content: effects on functionality, public health benefits and sensory properties. Trends in Food Science and Technology, 22: 276-291.

Da Costa, M., Deliza, R., Rosenthal, A., Hedderley, D., \& Frewer, L. (2000). Non conventional technologies and impact on consumer behaviour. Trends in Food Sci. Technol. 11: 188-193.

Deliza, R., Macfie, A., and Hedderley, A. (2003). Consumer attitude towards information on non conventional technology. Trends in Food Science and Technology, 14: 43-49

Dickinson, E. (2007). Food colloids... How do interactions of ingredients control structure, stability and rheology? Current Opinion in Colloid \& Interface Science, 12: 155-157.

Dodds, W. B., Monroe, K. B. \& Grewal, D. (1991). Effects of Price, Brand, and Store Information on Buyers' Product Evaluations. Journal of Marketing Research, 28: 307-319

El-Bakry, M., Beninati, F., Duggan, E., O'Riordan, E. D., \& O'Sullivan, M. (2011). Reducing salt in imitation cheese: effects on manufacture and functional properties. Food Research International, 44: 589-596.

EUR 1859. (2000). Scientific concepts of functional food in Europe. Project Report. Vol. 3- Dg Research-RTD actions: life sciences and Technologies. Bruselas. Bélgica. 
Flamm, G., Glinsmann, W., Kritchvkky, D., Prosky, L., \& Roberfroid, M. (2001). Inulin and Oligofructose as Dietary Fiber: A Review of the Evidence. Critical Reviews in Food Science and Nutrition, 41: 353-362.

Fric, P. (2007). Probiotics and prebiotics - renaissance of a therapeutic principle. Central European Journal of Medicine, 2: 237-270.

Gibson, G. R. 2004. Fibre and effects on probiotics (the prebiotic concept). Clinical Nutrition Supplements, 1: 25-31.

Gibson, G. R. \& Roberfroid, M. B. (1995). Dietary modulation of the human colonic microflora: Introducing the concept of prebiotics. Journal of Nutrition, 125: 1401-1412.

González-Tomás, L., Bayarri, S., \& Costell, E. (2009). Inulin-enriched dairy desserts: Physicochemical and sensory aspectsJournal of Dairy Science, 92(9): 4188-4199.

Graham, S., Dayal, H., Swanson, M., Mittleman, A. \& Wilkinson, G. (1978). Diet in the epidemiology of cancer of the colon and rectum. Journal of the National Cancer Insitute, 61: 709-714.

Grummer, J., Karalus, M., Zhang, K., Vickers, Z., \& Schoenfuss, T. C. (2012). Manufacture of reduced-sodium Cheddar-style cheese with mineral salt replacers. Journal of Dairy Science, 95: 2830-2839.

Guerrero, L., Colomer, Y., Guàrdia, M.D., Xicola, J., \& Clotet, R. (2000). Consumer attitude towards store brands. Food Quality and Preference, 11: 387-395.

Guttierres, R. \& Barreto, A. L. (2010). Characterization of Requeijao cheese potentially prebiotic by the addition of inulin and soy protein. Boletim do Centro de Pesquisa e Processamento de Alimentos, 28: 289-302.

Hennelly, P. J., Dunne, P. G., O'Sullivan, M., y O'Riordan, E. D. (2006). Textural, rheological and microstructural properties of imitation cheese containing inulin. Journal of Food Engineering, 75: 388-395. 
Heredia, A., Jimenez, A., Fernandez-Bolanos, J., Guillen, R. \& Rodriguez, R. (2002). Fibra Alimentaria. pp 1- 117. Biblioteca de Ciencias, Madrid.

Hilliam, M. (2003). Future for dairy products and ingredients in the functional foods market. Australian Journal of Dairy Technology, 58: 98-103.

Holm F. (2003). New Functional Food Ingredients Cardiovascular Health. Food Group Denmark, Skødstrup, Denmark, 8-31.

IFIC (2007). Consumer Attitudes toward Functional Foods/ Foods for Health. International Food Information Council (IFIC) and IFIC Foundation. Disponible en: http://ific.org.

Jaeger, S. R. (2006). Non-sensory factors in sensory science research. Food Quality and Preference, 17: 132-144.

Jago, D. (2009). Functional foods, market trends. Paper presented at the Functional Foods Symposium, Amsterdam, The Netherlands.

Jones, P. J., \& Jew, S. (2007). Functional food development: Concept to reality. Trends in Food Science and Technology, 18: 387-390.

Kaur, S. \& Das, M. (2011). Functional Foods: An Overview. Food Science Biotechnology, 20(4): 861-875.

Kaur, N., \& Grupta, A. (2002). Applications of inulin and oligofructose in health and nutrition. Journal of Biosciences, 27: 703-714.

Keller, K. L., Heckler, S. E. \& Houston, M. J. (1998). The Effects of Brand Name Suggestiveness on Advertising Recall. Journal of Marketing, 62: 48-57.

Klimas, M., Brethour, C. \& Bucknell, D. (2008). Introduction and background. p. 3. In: International Market Trends Analysis for the Functional Foods and Natural Health Products Industry in the United States, Australia, the United Kingdom, and Japan. March 17, Nutri-Net Canada, Ontario, Canada. 
Koca, N. \& Metin, M. (2003). Textural, melting and sensory properties of lowfat fresh kashar cheeses produced by using fat replacers. International Dairy Journal, 14: 365-373

Law, M. R. (1997). Epidemiologic Evidence on Salt and Blood Pressure. American Journal of Hypertension, 10: 42S-45S.

Let, M. B., Jacobsen, C., \& Meyer, A. S. (2007). Lipid oxidation in milk, yoghurt, and salad dressing enriched with neat fish oil or pre-emulsified fish oil. Journal of Agriculture and Food Chemistry, 55: 7802-9.

Lichtenstein, A.H., L.J. Appel, M. Brands, M. Carnethon \& S. Daniels et al., 2006. Diet and lifestyle recommendations revision 2006: A scientific statement from the American Heart Association Nutrition Committee. Circulation, 114: 82-96.

Lima, L., Mattanna, P., Vargas, L., Richards, N. S. P. S., \& Fontana de Andrade, D. (2008). Sensory evaluation of potentially symbiotic cream cheese using the surface response methodology. Alimentos e Nutricao, 19: 409416.

Lteif, L., Olabi, A., Kebbe Baghdadi, O. \& Toufeili, I. (2009). The characterization of the physicochemical and sensory properties of full-fat, reduced-fat, and low-fat ovine and bovine Halloumi. Journal of Dairy Science, 92: 4135-4145.

Lucca, P. A. \& Tepper, B. J. (1994). Fat replacers and the functionality of fat in foods Review Article. Trends in Food Science and Technology, 5: 12-19.

Luckow, T., Sheehan, V., Delahunty, C., \& Fitzgerald, G. (2005). Determining the odor and flavor characteristics of probiotic, health-promoting ingredients and the effects of repeated exposure on consumer acceptance. Journal of Food Science, 70: S53-S59.

Martini, S., Thurgood, J. E., Brothersen, C., Ward, R. \& McMahon, D. J. (2009). Fortification of reduced-fat Cheddar cheese with n-3 fatty acids: effect on off-flavor generation. Journal of Dairy Science, 92:1876-84. 
Mattes, R. (2007). Physiologic Responses to Sensory Stimulation by Food: Nutritional Implications. Journal of the American Dietetic Association, 97: 406-410.

Mela, D. J. (2001). Development and acquisition of food likes. In: Food, People and Society. A European Perspective of Consumers' Food Choices. L Frewer, E Risvik and H Schifferstein (Eds.). pp 9-21. Springer-Verlag. Berlin.

Menrad, K. (2003). Market and marketing of functional food in Europe. Journal of Food Engineering, 56: 181-188.

Mercenier, A., Pavan, S. \& Pot, B. (2002). Probiotics as biotherapeutic agents: present knowledge and future prospects. Current Pharmaceutical Design, 8: 99-110.

Mialon, V. S., Clark, M. R., Leppard, P. I. \& Cox, D. N. (2012). The effect of dietary fibre information on consumer responses to breads and "English" muffins: a cross-cultural study. Food Quality and Preference, 13: 1-12.

Mollet, B., \& Rowland, I. (2002). Functional foods: At the frontier between food and pharma. Current Opinion in Biotechnology, 13: 483-485.

OCDE-FAO. (2010). Perspectivas agrícolas 2010-2019. OCDE/FAO. Disponible en: $\quad$ http://www.scribd.com/doc/38109882/OCDE-FAO-PerspectivasAgricolas-sp-5110044e\#touter_page_187

O'Cass, A. \& Lim, K. (2001). The Influence of Brand Associations on Brand Preference and Purchase Intention: An Asian Perspective on Brand Associations. Journal of International Consumer Marketing, 14(2/3): 4170.

Petridis, D., Vlazakis, E. L, Tzivanos, I. A. K., Derlikis, E. M. \& Ritzoulis, C. (2010). Effects of selected ingredients and fat content on the sensory and mechanical properties of frankfurter-type sausages. Journal of Texture Studies, 41: 880-898. 
Prates, J.A.M. \& Mateus, C.M.R.P. (2002). Functional foods from animal sources and their physiologically active components. Revue de MédicineVéterinaire, 153(3): 155-160.

Purwanti, N., van der Goot, A., Boom, R. \& Vereijken, J. (2010). New directions towards structure formation and stability of protein-rich foods from globular proteins. Trends in Food Science \& Technology, 21: 85-94.

RBN (1994). REGLAMENTO BROMATOLÓGICO DE URUGUAY. Decreto

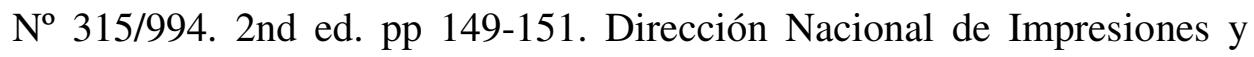
Publicaciones Oficiales. Montevideo, Uruguay.

Roberfroid, M. (2000). Concepts and strategy of functional food science: the European perspective. American Journal of Clinical Nutrition, 71: 1660S1664.

Roberfroid, M. (2007). Prebiotics: the concept revisited. Journal of Nutrition, 137: 830S-837S.

Roberfroid, M., \& Slavin, J. (2000). Nondigestible oligosaccharides. Critical reviews in Food Science and Nutrition, 40: 461-480.

Roberfroid, M., Van Loo, J., \& Gibson, G. 1998. The bifidogenic nature of chicory inulin and its hydrolysis products. Journal of Nutrition, 128:11-19.

Rowan, C. (2000). Packaging by design. Food Engineering International, 25: 1925.

Ritvanen, T., Lilleberg, L., Tupasela, T., Suhonen, U., Eerola, S., Putkonen, T., \& Peltonen, K. (2010). The characterization of the most-liked reduced-fat Havarti-type cheeses. Journal of Dairy Science, 93: 5039-5047.

Ruussunen, M. \& Poulanne, E. (2005). Reducing sodium intake from meat products. Meat Science, 70: 531-541.

Sabbe, S., Verbeke, W., Deliza, R., Matta, V., \& Van Damme, P. (2009). Effect of a health claim and personal characteristics on consumer acceptance of fruit juices with different concentrations of açaí (euterpe oleracea mart.). Appetite, 53(1): 84-92. 
Saiz, Y. H. (2011). Spanish Council for Scientific Research. Available from: http://www.geoscopio.org/est/gmms/ott en/Postharvest treatment of table grapes to increase the content of the antioxidant and anticarcinogenic component resveratrol using UV irradiation pulses.

Sanders, M. E. (1998). Overview of functional foods: emphasis on probiotic bacteria. International Dairy Journal, 8: 341-349

Shepherd, R. (1989). Factors influencing food preferences and choice. In: Handbook of the Psychobiology of Human Eating (Ed. R. Shepherd), pp. 3-14. John Wiley \& Sons Ltd, Chichester.

Shepherd, R. \& Sparks, P. (1994). Modelling food choice. In: Measurement of Food Preferences (Eds. D.M.H. Thomson \& H.J.H. MacFie), p. 202-226. Blackie Academic and Professional, London.

Siró, I., Kàpolna, E., Kàpolna, B. \& Lugasi, A. (2008). Functional food. Product development, marketing, and consumer acceptance-A review. Appetite, 51: 456-467.

Slavin, J., Jacobs, D. \& Marquart, L. (2000). Grain processing and nutrition. Critical Reviews in Food Science and Nutrition, 4: 309-326.

Steed, H. \& Macfarlane, S. (2009). Mechanisms of prebiotic impact on health, in Prebiotics and Probiotics Science and Technology, ed. by Charalampopoulos D and Rastall RA. pp. 135-161. Springer, New York, NY.

Steptoe, A., Pollard, T. M. \& Wardle, J. (1995) The development of a measure of the motives underlying the selection of food: the Food Choice Questionnaire. Appetite, 25: 267-284.

Tannock, G. W. (1999). Introduction. In: Tannock, G.W. (Ed.), Probiotics: A Critical Review, Horizon Scientific Press. pp. 1-4. Norfolk, UK.

Tarakci, Z \& Kucukoner, E. 2006. Note: Effect of Different Cultures on Physicochemical and Sensory Properties of Low-fat Herby Cheese. Food Science and Technology International, 12(5): 423-428. 
Tarrega, A., Rocafull, A. \& Costell, E. (2010). Effect of blends of short and longchain inulin on the rheological and sensory properties of prebiotic low-fat custards. LWT -- Food Science and Technology, 43: 556-562.

Torres, J. D., Tarrega, A. \& Costell, E. (2010). Storage stability of starch-based dairy desserts containing long-chain inulin: rheology and particle size distribution. International Dairy Journal, 20: 46-52.

Torres, M., Tárrega, A., Torrescana, E., \& Blanch, C. (2012). Influence of label information on dark chocolate acceptability. Appetite, 58: 665-671.

Tungland, B., \& Meyer, D. (2002). Non-digestible Oligosaccharides (Dietary Fibre): Their Physiology and Role in Human Health and Food. Comprehensive Reviews in Food Science and Food Safety, 3: 73-92.

Tuomilehto, J., Lindström, J., Eriksson, J. G., Valle, T. T., Hämäläinen, H., et al. (2001). Prevention of type 2 diabetes mellitus by changes in lifestyle among subjects with impaired glucose tolerance. New England Journal of Medicine, 344 (18): 1343-1350.

Tuorila, H., \& Cardello, A. V. (2002). Consumer response to an off-flavour in juice in the presence of specific health claims. Food Quality and Preference, 13: 561-569.

van Trijp, H. C. M., \& van der Lans, I. A. (2007). Consumer perceptions of nutrition and health claims. Appetite, 48: 305-324.

Varela, P., Ares, G., Giménez, A., \& Gámbaro, A. (2010). Influence of brand information on consumers' expectations and liking of powered drinks in central location tests. Food Quality and Preference, 21: 873-880.

Verbeke, W. (2005). Consumer acceptance of functional foods: sociodemographic, cognitive and attitudinal determinants. Food Quality and Preference, 16: 45-57.

Verbeke, W. (2006). Functional foods: Consumer willingness to compromise on taste for health? Food Quality and Preference, 17: 126-131. 
Villegas, B., Carbonell, I. \& Costell, E. (2007). Flow behaviour of inulin-milk beverages. Influence of inulin average chain length and of milk fat content. International Dairy Journal, 17: 776-781

Villegas, B. Carbonell, I. \& Costell, E. (2008). Effects of product information and consumer attitudes on responses to milk and soybean vanilla beverages. Journal of the Science of Food and Agriculture, 88: 24262434.

Vithanage, C. J., Mishra, V. K., Vasiljevic, T., \& Shah, N. P. (2008). Use of beta-glucan in development of low-fat mozzarella cheese. Milchwissenschaft, 63: 420-423.

Walter, B., Schmid, A., Steber, R., \& Wermüller, K. (2008). Cheese in nutrition and health. Dairy Science and Technology, 88(4-5): 389-405.

Wilcock, A., Pun, M., Khanona, J., \& Aung, M. (2004). Consumer attitudes, knowledge and behaviour: a review of food safety issues. Trends Food Science and Technology, 15: 56-66.

Wills, J. M., Storcksdieck genannt Bonsmann, S., Kolka, M. \& Grunert, K. G. (2012). European consumers and health claims: attitudes, understanding and purchasing behaviour. Proceedings of the Nutrition Society, 71: 229236.

WHO (2003). Reported of Joint WHO/FAO expert consultation on diet, nutrition and the prevention of chronic diseases. Geneva: Switzerland. Retrieved June 29, 2009. Available from:

http://www. who.int/hpr/NPH/docs/who_fao_experts_report.pdf

Worsley, A., \& Skrzypiec, G. (1998). Environmental attitudes of senior secondary school students in South Australia. Global Environmental Change-Human and Policy Dimensions, 8: 209-225.

Young, Y. (2000). Functional foods and the European consumer. In J. Buttriss \& M. Saltmarsh (Eds.), Functional foods. II. Claims and evidence. London, UK: The Royal Society of Chemistry. 
OBJETIVOS 

El objetivo general de esta tesis fue contribuir al conocimiento de la influencia de la variabilidad de las características sensoriales y de las no-sensoriales en la respuesta del consumidor a los alimentos, especialmente frente aquellos con unas características nutricionales específicas. En este contexto se plantearon los siguientes objetivos específicos:

- Investigar los factores que determinan la respuesta del consumidor frente a productos con diferentes características nutricionales y sensoriales:

- Determinar el potencial interés de los consumidores uruguayos en la adquisición y consumo de quesos con diferentes beneficios nutricionales.

- Caracterizar las diferencias sensoriales entre quesos uruguayos comerciales con bajo contenido en grasa (magro) y establecer la relación con su aceptabilidad.

- Investigar el efecto de las expectativas creadas por la etiqueta en la aceptabilidad de quesos uruguayos comerciales con bajo contenido en grasa.

- Desarrollar y optimizar la calidad sensorial de un nuevo producto lácteo funcional con carácter prebiótico y con bajo contenido en grasa y en azúcar

- Estudiar el efecto de la adición de inulina en el comportamiento reológico y en la consistencia percibida en sistemas modelo de postres lácteos

- Optimizar la aceptabilidad de la formulación del nuevo postre prebiótico aplicando la Metodología de Superficie de Respuesta. 



\section{PRESENTACIÓN DE LOS}

TRABAJOS 

De acuerdo a los objetivos planteados, esta tesis se divide en dos partes: 1- El estudio de los factores que influyen en la respuesta de los consumidores uruguayos a quesos con beneficios nutricionales (capítulos 1, 2 y 3) y 2- El estudio de la influencia de la composición en las características fisico-químicas y en la aceptabilidad de postres enriquecidos con inulina y optimización de la aceptabilidad de una nueva formulación de postre lácteo (capítulos 4, 5 y 6).

\section{Capítulo 1:}

Arcia, P., Curutchet, A., Costell, E., Tárrega, A. Response of Uruguayan consumers to cheeses with health benefits. Enviado a: Appetite.

\section{Capítulo 2:}

Arcia, P., Curutchet, A., Costell, E., Tárrega, A. Sensory properties and acceptance of Uruguayan low-fat cheeses. Enviado a: Journal of Dairy Science \& Technology.

\section{Capítulo 3:}

Arcia, P., Curutchet, A., Costell, E., Tárrega, A. Influence of expectations created by label on consumers acceptance of Uruguayan low-fat cheeses. Aceptado para publicación: Journal of Sensory Studies.

\section{Capítulo 4:}

Arcia, P., Navarro, S., Costell, E., Tárrega, A. 2011. Effect of inulin seeding on rheology and microstructure of prebiotic dairy desserts. Food Biophysics, 6: 440449. 


\section{Capítulo 5:}

Arcia, P., Costell, E., Tárrega, A. 2011. Thickness suitability of prebiotic dairy desserts: Relationship with rheological properties. Food Research International. 43 (10): 2409-2416

\section{Capítulo 6:}

Arcia, P., Costell, E., Tárrega, A. 2011. Inulin blend as prebiotic and fat replacer in dairy desserts: Optimization by Response Surface Methodology. Journal of Dairy Science, 94: 2192-2200. 


\section{CAPÍTULO 1}

\section{Response of Uruguayan consumers to cheeses with health benefits}





\title{
RESPONSE OF URUGUAYAN CONSUMERS TO CHEESES WITH HEALTH BENEFITS
}

\author{
P. L. Arcia ${ }^{\mathrm{a}, \mathrm{b}}$, A. Curutchet ${ }^{\mathrm{a}}$, E. Costell ${ }^{\mathrm{b}}$, A. Tárrega ${ }^{\mathrm{b}}$ \\ a Laboratorio Tecnológico del Uruguay, Montevideo, Uruguay. Av. Italia 6201, C.P. 11500. Montevideo, \\ Uruguay. \\ ${ }^{\mathrm{b}}$ Physical and Sensory Properties Laboratory. Instituto de Agroquímica y Tecnología de Alimentos, \\ CSIC. Avda. Agustín Escardino, 7. 46980 Paterna (Valencia) Spain
}

\section{HIGLIGHTS}

Consumer's interest for health benefits in spreadable and Dambo cheese was evaluated.

Among the different options, low-fat cheeses were considered of greater interest. Consumer's motives to buy cheeses with health benefits were to achieve a better quality life and to look more attractive. Expected lack of pleasure and distrust were the basic reasons for rejecting a cheese with health benefits.

\begin{abstract}
This work aimed to study and explain the response of Uruguayan consumers to cheeses with different nutritional and commercial characteristics. Conjoint analysis was used to establish the value that consumers gave to different health benefits (low-fat, salt-reduced, fiber-enriched, probiotic) and to different manufacturing processes (traditional and industrial). Laddering technique was applied to understand consumers' underlying motives for purchasing, or not purchasing, cheese with different health claims. Results indicated that
\end{abstract}


consumers' interest varied depending on the proposed health benefit. In general consumers' interest in cheese with specific nutritional benefits was lower than for the regular product. However consumer segmentation showed that some groups were willing to consume cheeses with health benefits and, among the different options, low-fat cheeses were considered of greater interest. Laddering analysis revealed that these consumers were interested in looking more attractive and achieving a better quality life. The main reasons given by the other consumers for not buying cheese with health benefits were expected lack of pleasure and distrust in the claimed health benefit.

Keywords: cheese, health benefits, conjoint analysis, laddering, motives to purchase,

\section{INTRODUCTION}

The growing interest in a healthy diet has prompted the food industry to develop products with specific health benefits. Recent years have witnessed an increase in the number of products incorporating new ingredients such as fiber, prebiotics, probiotics, vitamins, minerals and antioxidants, or those with reduced content of certain components like fat, sodium or sugar. However, not all consumers consider the possible health benefit of a food to be an added value, thus it is not always a guarantee of a product's market success. The acceptance of a food depends on the interaction between the food and the consumer (Shepherd, 1989). On one hand, consumer response to a product can vary greatly depending on consumer characteristics (Bruhn et al., 1992; Wilcock, Pun, Khanona, \& Aung, 2004; Guerrero, Colomer, Guàrdia, Xicola, \& Clotet, 2000; Caporale \& Monteleone, 2001; van Kleef, van Trijp, Luning, \& Jongen, 2002; Sijtsema, Backus, Linnemann, \& Jongen , 2002) and their motivations due to particular 
interest in health, weight concerns, sensory pleasure, ideological reasons, convenience, price or familiarity (Crossley \& Khan, 2001; Lindeman \& Stark, 1999). On the other hand, consumers' reaction to health benefits can also differ depending on the type of food. Functional foods are not perceived by consumers as a homogenous category and the reasons for choosing a functional product differ within different food categories (Urala \& Lähteenmäki, 2004, 2007; Ares \& Gámbaro, 2004). Consumers perceive products that are intrinsically healthy such as yogurt, cereals and juice, as preferable and credible carriers for functional ingredients (Annunziata \&Vecchio, 2011).

Ares, Giménez and Gámbaro (2008) showed that Uruguayan consumers were in general willing to consume food products with a positive impact on their health, particularly those that could reduce the risk of cardiovascular diseases or cancer, or boost their immune system. In Uruguay, as in the rest of the world, dairy is the sector that has expanded most with the introduction of functional products (Menrad, 2003, Siró, Kápolna, Kápolna, \& Lugasi, 2008). Among them, yogurtlike products (enriched with fiber, vitamins or omega-3, prebiotics or probiotic) are the most popular. Cheese is a widely consumed dairy product and it is also an interesting alternative to develop healthy products (Awaisheh, 2011; Rodrigues, et al. 2011; Guttierres \& Barreto, 2010; Fritzen-Freire, Müller, Laurindo, \& Prudêncio, 2010; Noronha, O'Riordan, \& O'Sullivan, 2007). For this it is important to identify which health benefits of cheese interest consumers most. To date there is no information about Uruguayan consumers' opinion on cheeses with specific nutritional characteristics.

It should also be taken into account that Uruguayan consumers may also be concerned with the type of cheese manufacturing process employed. In Uruguay, cheeses are produced by both big dairy industries and small producers, which consumers relate with industrial and traditional manufacture, respectively. For some consumers, traditionally manufactured products are linked to cultural 
heritage (Guerrero et al., 2009; Trichopoulou, Soukara, \& Vasilopoulou, 2007) and to the sustainability of rural areas.

Conjoint analysis is a technique often used in market research to determine which characteristics of a product are most interesting or attractive to a consumer (Moskowitz \& Silcher, 2006). It can be applied to determine which functional benefits or nutritional claims consumers may consider more attractive or reliable (Moskowitz, Beckley, \& Minkus-McKenna, 2004, Drewnowski, Aggarwal, Hurvitz, Hastert, \& Moudon, 2010). Laddering can be a complementary technique to understand how product information is processed by consumers. Laddering is based on an in-depth one-to-one interviewing technique, following Means-End Theory (Gutman, 1982). The main goal of laddering is to determine sets of links between the key perceptual elements across the range of attributes, consequences and values. These association networks, or ladders, represent combinations of elements that serve as the basis for distinguishing between and among products in a given product class (Sørensen \& Askegaard, 2007).

The aims of this work were to determine the value that Uruguayan consumers give to different health benefits on spreadable and semi-soft cheese, and to better understand the differences in opinion towards the health benefits.

\section{MATERIALS AND METHODS}

\section{Conjoint study}

\section{Design}

The study was carried out separately for two well known types of cheese in Uruguay: a spreadable cheese and a semi-soft cheese (Dambo cheese). For each of them two factors were considered: different health benefits and different types of manufacturing process. The first factor comprised five levels: four different 
health benefits (low-fat, salt-reduced, fiber-enriched and probiotic) and a regular product. In the second factor, the traditional and industrial processes were taken into account (Table 1). The two factors varied independently following a full factorial design of $5 \times 2$. So, ten vignettes with the description of the product combining both factors were created for each type of cheese.

Table 1. Influence of health benefits and type of processing on consumer interest for cheeses. Factors and levels considered in the conjoint design.

\begin{tabular}{ll}
\hline Factor & Description \\
\hline & Low-fat \\
Health benefit & Salt-reduced \\
& Fiber-enriched \\
& With Bífidus \\
& None (regular) \\
& \\
Type of processing & Traditional \\
& Industrial \\
\hline
\end{tabular}

\section{Surveys}

The survey was uploaded to a web server (application Google Docs-Home of Google) and the link to gain access was sent to a list of two hundred and fifty email recipients. In the survey, each one of the ten vignettes generated was presented monadically and the respondent had to indicate the degree of interest in each hypothetical product by using a 9-point scale, from "I'm not interested at all" to "I'm very interested". After that, participants completed the General Health Interest questionnaire proposed by Roininen, Lähteenmäki andTuorila (1999) using the Spanish version reported by Villegas, Carbonell and Costell (2008) (Table 2). Finally, respondents completed some demographic questions. One hundred and sixty two people completed the survey. $61 \%$ were women and 
$39 \%$ were men. The $67 \%$ of participants were from 18 to 40 years old and the $33 \%$ from 40 to 66 years old.

Table 2. General health interests multiple scale. Extracted from Roininen et al. (1999)

\begin{tabular}{l}
\hline Items \\
$\begin{array}{l}\text { 1. R } \\
\text { 2. }\end{array}$ Ihe healthiness of food has little impact on my food choices. \\
3. R I eat what I like and I do not worry much about the healthiness of food. \\
4. It is important for me that my diet is low in fat. \\
5. I always follow a healthy and balanced diet. \\
6. It is important for me that my daily diet contains a lot of vitamins and \\
7. R The healthiness of snacks makes no difference to me. \\
8. R I do not avoid foods, even if they may raise my cholesterol.
\end{tabular}

Negative statements (marked with an "R" after the statement number) are recoded for the final score.

\section{Soft laddering}

Five different versions of Dambo cheese labels were created varying the health benefit indicated on it. Figure 1 shows as example two of the five labels created. A group of 41 consumers (68\% were women and 32\% were men; 54\% from 18 to 40 years old and $46 \%$ from 40 to 66 years old) participated in this evaluation. Each consumer was interviewed in an individual session of 30-45 minutes. First, the five labels were simultaneously presented and the interviewer asked the participant: "If you were at the supermarket buying cheese, which of these 
cheeses would you choose according to their label? And from the remaining samples, which would you chose? And then?" Thus the interviewer continued asking until the rank order of choice was completed for all five labels. Secondly, each label was presented individually to the consumer, who was asked if he/ she would buy, or not, the corresponding cheese. Finally, the consumer's reasons for buying or for not buying the product were established using a series of "why" questions (Sørensen \& Askegaard, 2007).

a)
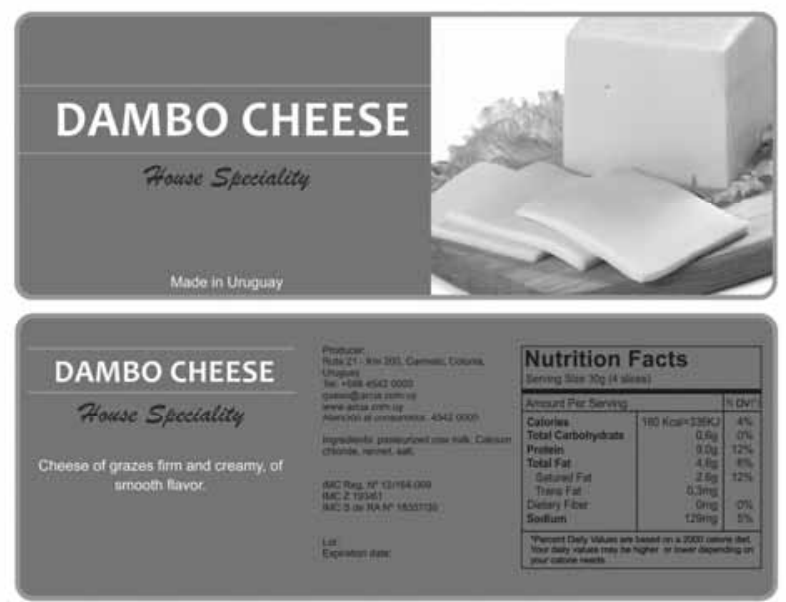

b)
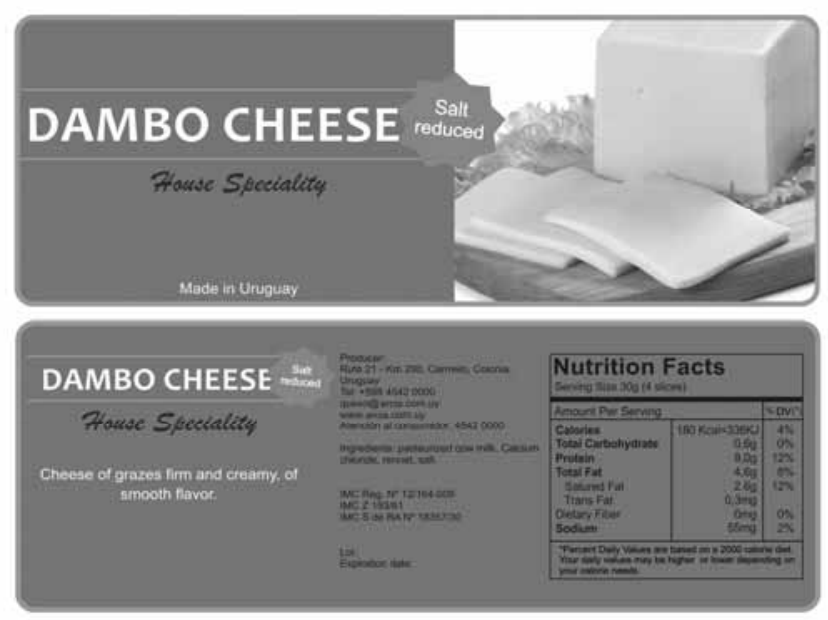

Figure 1. Examples of two labels created for this study, a cheese without a specific healthy benefit (a) and a cheese with salt-reduced (b). 


\section{Data analysis}

To study the variability in consumers' interest in the cheeses described in the vignettes, a mixed ANOVA of three factors, two fixed (health benefit and type of processing) with interaction and one random (consumer) was applied. When the effects were significant, differences were calculated using Tukey's test ( $\alpha=0.05)$. The utility value for each factor level was obtained from the ANOVA regression mode. These analyses were performed for the total consumer panel and for each consumer group showing a similar interest in each of the ten cheeses described in the vignettes. To identify these groups of consumers, hierarchical cluster analysis considering Euclidean distances and with Ward's aggregation method were applied.

Composition of each cluster according to consumer gender, age and interest in a healthy diet were compared using the Chi-square test. Significant differences among proportions were determined using Marascuilo procedure (Levy, 1975).

To analyze the order of choice of the Dambo cheese labels, the Friedman Analysis of Variance was applied and significance of differences between samples determined by the Fisher test $(\alpha=0.05)$, as modified for non-parametric data (Meilgaard, Civille, \& Carr, 1999). Data from the laddering task were analyzed as proposed by Reynolds and Gutman (1988). Attributes, consequences and values having the same meaning were grouped together and coded. With this information, diagrams showing relationships among attributes, consequences and values (Hierarchical value maps: HVM) were constructed.

Data analyses were performed using the software XLSTAT 2011.1.02 Version (Addinsoft, France). 


\section{RESULTS}

Effect of health benefits and type of processing on consumers' interest in cheese

The scores of interest shown by consumers in the cheeses described in vignettes ranged from 4.1 to 6 for spreadable cheese and from 4.5 to 6.6 for Dambo cheese. ANOVA results indicated that the two conjoint factors, health benefit and manufacture type, had a significant effect on consumers' interest in spreadable cheese (Table 3). However, for Dambo cheese only the health benefit factor had a significant effect on consumers' interest. For the two types of cheeses, the interaction between the two factors was not significant indicating that their interest in the nutritional benefit of the cheeses did not depend on cheese processing type. A model relating consumers' interest and the different factor levels was obtained to determine the utility value for each of the studied characteristics (Table 4). For both types of cheeses, positive utility values were obtained for both low-fat and regular products and negative utility values for the other three options (probiotic, fiber-enriched and salt-reduced). For spreadable cheese, consumers were more interested in low-fat product than in the regular one.

Table 3. Influence of information about health benefit and manufacture type on consumer interest on spreadable and Dambo cheeses. Results of Analysis of Variance. $F(4,1,4)$ ratio and probability $(p)$ values.

\begin{tabular}{lcccc}
\hline & \multicolumn{2}{c}{ Spreadable cheese } & \multicolumn{2}{c}{ Dambo cheese } \\
\cline { 2 - 5 } Source & $\mathrm{F}$ & $\mathrm{p}$ & $\mathrm{F}$ & $\mathrm{p}$ \\
\hline Health benefit & 41.0 & 0.000 & 59.8 & 0.000 \\
Manufacture type & 7.5 & 0.006 & 0.5 & 0.460 \\
Health benefit x Manufacture type & 0.3 & 0.858 & 0.7 & 0.617 \\
\hline
\end{tabular}


Table 4. Values of the parameters of the utility model for spreadable and Dambo cheeses in relation with health benefits and processing type.

\begin{tabular}{clcc}
\hline \multirow{2}{*}{ Factor } & \multicolumn{1}{c}{ Level } & \multicolumn{2}{c}{ Utility values } \\
\cline { 3 - 4 } & & Spreadable cheese & Dambo cheese \\
\hline \multirow{5}{*}{ Health benefit } & $0.79^{\mathrm{a}}$ & $0.55^{\mathrm{b}}$ \\
& Fiber-enriched & $-0.47^{\mathrm{b}}$ & $-0.70^{\mathrm{c}}$ \\
& With Bifidus & $-0.42^{\mathrm{b}}$ & $-0.69^{\mathrm{c}}$ \\
& Salt-reduced & $-0.69^{\mathrm{b}}$ & $-0.42^{\mathrm{c}}$ \\
& None & $0.79^{\mathrm{a}}$ & $1.25^{\mathrm{a}}$ \\
\hline \multirow{2}{*}{ Process } & Industrial & $0.14^{\mathrm{a}}$ & -0.04 \\
& Traditional & $-0.14^{\mathrm{b}}$ & 0.04 \\
\hline
\end{tabular}

Value of the constant in the model was 4.97 and 5.31 for spreadable cheese and Dambo cheese, respectively

Within each column, mean values followed by different letters are significantly different $(\mathrm{p} \leq$ $0.05)$.

For Dambo cheese, the utility for low fat product was significantly lower than that for the regular product. The effect of the processing type was only significant for spreadable cheese. These results show that consumers were interested only in the low-fat cheeses. In general, they were not interested for the other nutritional alternatives considered in this study. To identify the possible different patterns in consumer response, hierarchical cluster analysis was performed to segment consumers according to their interest in each of the different options presented. Three groups of consumers were identified for spreadable cheese. For all of them, both factors significantly affected their interest in the product (Table 5). 
Table 5. Influence of information about health benefit and manufacture type on consumer interest on spreadable cheeses. Results of Analysis of Variance. F (4, $1,4)$ ratio and probability $(\mathrm{p})$ values.

\begin{tabular}{lcccccc}
\hline & \multicolumn{2}{c}{ Cluster 1 } & \multicolumn{2}{c}{ Cluster 2 } & \multicolumn{2}{c}{ Cluster 3 } \\
\cline { 2 - 7 } Source & $\mathrm{F}$ & $\mathrm{p}$ & $\mathrm{F}$ & $\mathrm{p}$ & $\mathrm{F}$ & $\mathrm{p}$ \\
\hline Health benefit & 11.9 & 0.000 & 20.7 & 0.000 & 28.3 & 0.000 \\
Manufacture type & 28.1 & 0.000 & 50.3 & 0.000 & 8.4 & 0.004 \\
Health benefit x Manufacture type & 0.9 & 0.486 & 0.6 & 0.663 & 3.1 & 0.016 \\
\hline
\end{tabular}

In Figure 2 the utility values obtained from the model are represented for each group. For cluster 1 ( $40 \%$ of consumers) the value of the constant of the model was high (6.5) and the variation in the interest caused by the health benefit factor was low (1.5) (Figure 2). The high value of the constant indicates that in general these consumers were interested in all spreadable cheeses. Consumers were significantly more interested in the low-fat than in the rest of the health benefits. Their interest in salt-reduced and fiber-enriched cheeses did not significantly differ from that for the regular cheese, while interest in cheese with bifidus was the lowest. These consumers were also found to be more interested in traditional than in industrial manufacturing methods. For cluster 2 (33\% of consumers), the value of the constant was moderate (4.8) and the two studied factors had an important impact on consumers' interest (Figure 2). Consumers in this cluster were interested in cheeses with low-fat, and with bifidus and also in regular cheeses and they preferred industrially manufactured cheeses. In the case of cluster 3 (27\% of consumers), the constant value was very low (2.9) and the variation related to changes in cheese composition was very high (2.4). These consumers were only interested in regular cheese (Figure 2). Only for this group the interaction between health benefit and processing type was significant (Table 5). Industrial manufacture only increased consumers' interest in the case of the regular product. 

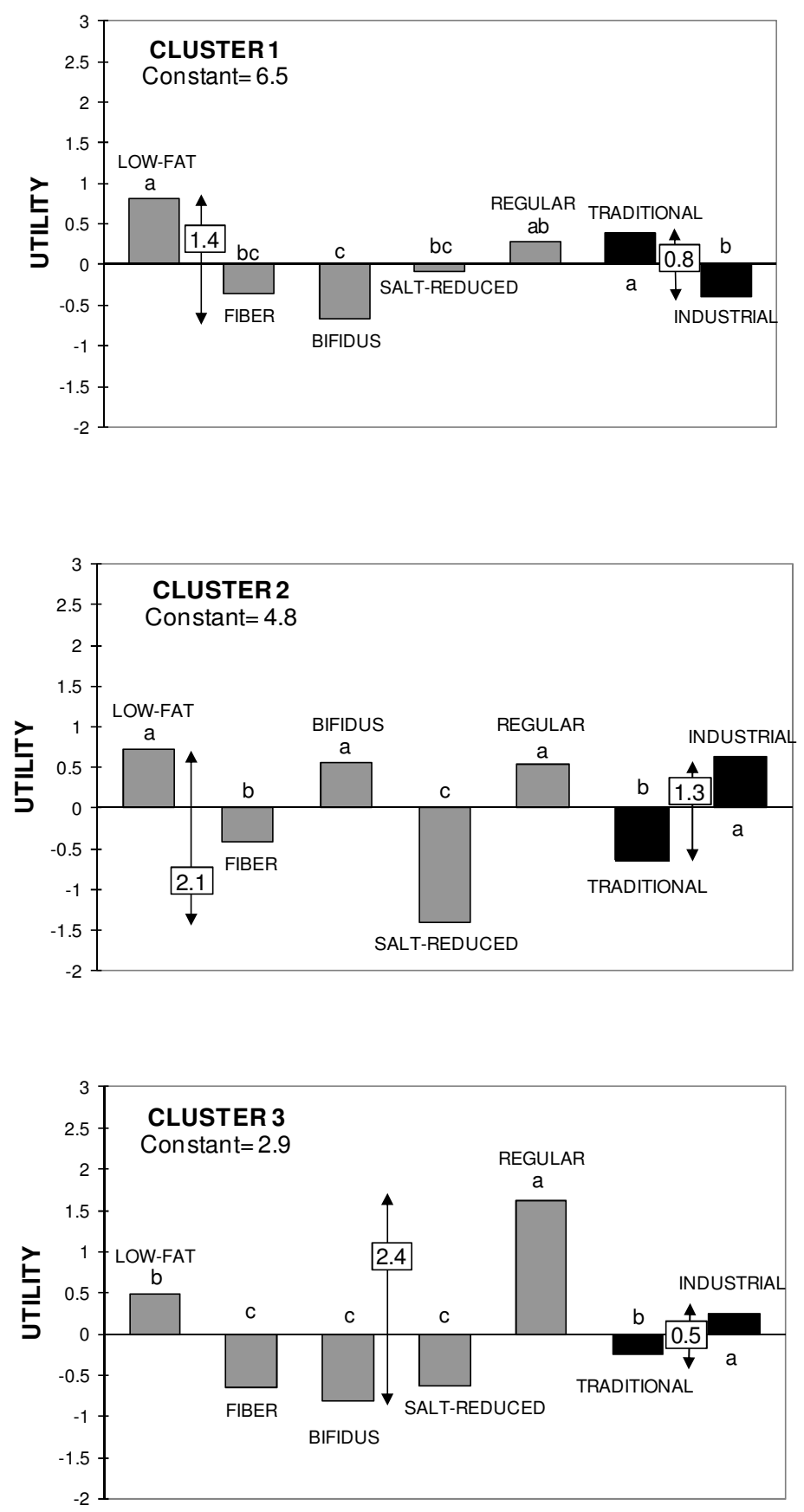

Figure 2. Mean utility values of the studied characteristic for spreadable cheese and for each consumers cluster. For each factor (health benefit $\square$; processing type $\square)$, values not sharing letters are significantly different $(\mathrm{p} \leq 0.05)$. 
For Dambo cheese, hierarchical cluster analysis also revealed 3 groups of consumers. For the three groups the two factors significantly affected the interest in the product (Table 6 ). Cluster 1 (38\% of consumers) showed a high value for the constant (7.0) and the variation in interest related to the health benefit factor was relatively low (1.4) (Figure 3). Salt reduction was the option of least interest to this group, while interest in the other health benefits did not significantly differ from that for regular cheese. This group preferred traditionally processed Dambo cheese. In cluster 2 (43\% of consumers), consumers' interest was affected only by the composition characteristic while the type of processing did not have a significant effect (Table 6). These consumers were interested in the regular cheese and in the low fat cheese (Figure 3). The last group of consumers (cluster 3; $19 \%$ of consumers) were only interested in regular Dambo cheese and consumer interest in this type of cheese slightly increased with traditional processing. Results indicate that consumer interest in cheese with health benefits varied among consumers. There was a group of consumers for whom most health benefits did not differ from interest in regular cheese (cluster 1 for both Dambo and spreadable cheeses). Another group of consumers that were mainly interested in low-fat benefit and regular product (cluster 2) and there were consumers that were not interested in health benefits at all (cluster 3). According to Ares, Giménez and Deliza, 2010, Uruguayan consumers have a greater intention of purchasing functional yogurts than regular yogurts. However, the results of the present study showed that for cheeses the information about the health benefits did not provided a higher utility value than that of the regular product. This suggests that a health benefit in these two types of cheese was not considered as an added value by Uruguayan consumers. Differences observed between consumer response to yogurt and cheese would confirm the idea that consumers react differently to functional benefits among different food types (Urala \& Lähteenmäki, 2007). Yogurt can be considered a healthy product, and consumers 
are familiar with new varieties of the product (taste and composition) while cheese is considered a more traditional product, which is well accepted in itself.

Table 6. Influence of information about health benefit and manufacture type on consumer interest on Dambo cheeses. Results of Analysis of Variance. F $(4,1,4)$ ratio and probability $(\mathrm{p})$ values.

\begin{tabular}{lcccccc}
\hline & \multicolumn{2}{c}{ Cluster 1 } & \multicolumn{2}{c}{ Cluster 2 } & \multicolumn{2}{c}{ Cluster 3 } \\
\cline { 2 - 7 } Source & $\mathrm{F}$ & $\mathrm{p}$ & $\mathrm{F}$ & $\mathrm{p}$ & $\mathrm{F}$ & $\mathrm{p}$ \\
\hline Health benefit & 20.2 & 0.000 & 32.6 & 0.000 & 51.0 & 0.000 \\
Manufacture type & 19.2 & 0.000 & 2.7 & 0.102 & 0.0 & 0.900 \\
Health benefit x Manufacture type & 0.9 & 0.459 & 0.8 & 0.502 & 2.6 & 0.038 \\
\hline
\end{tabular}



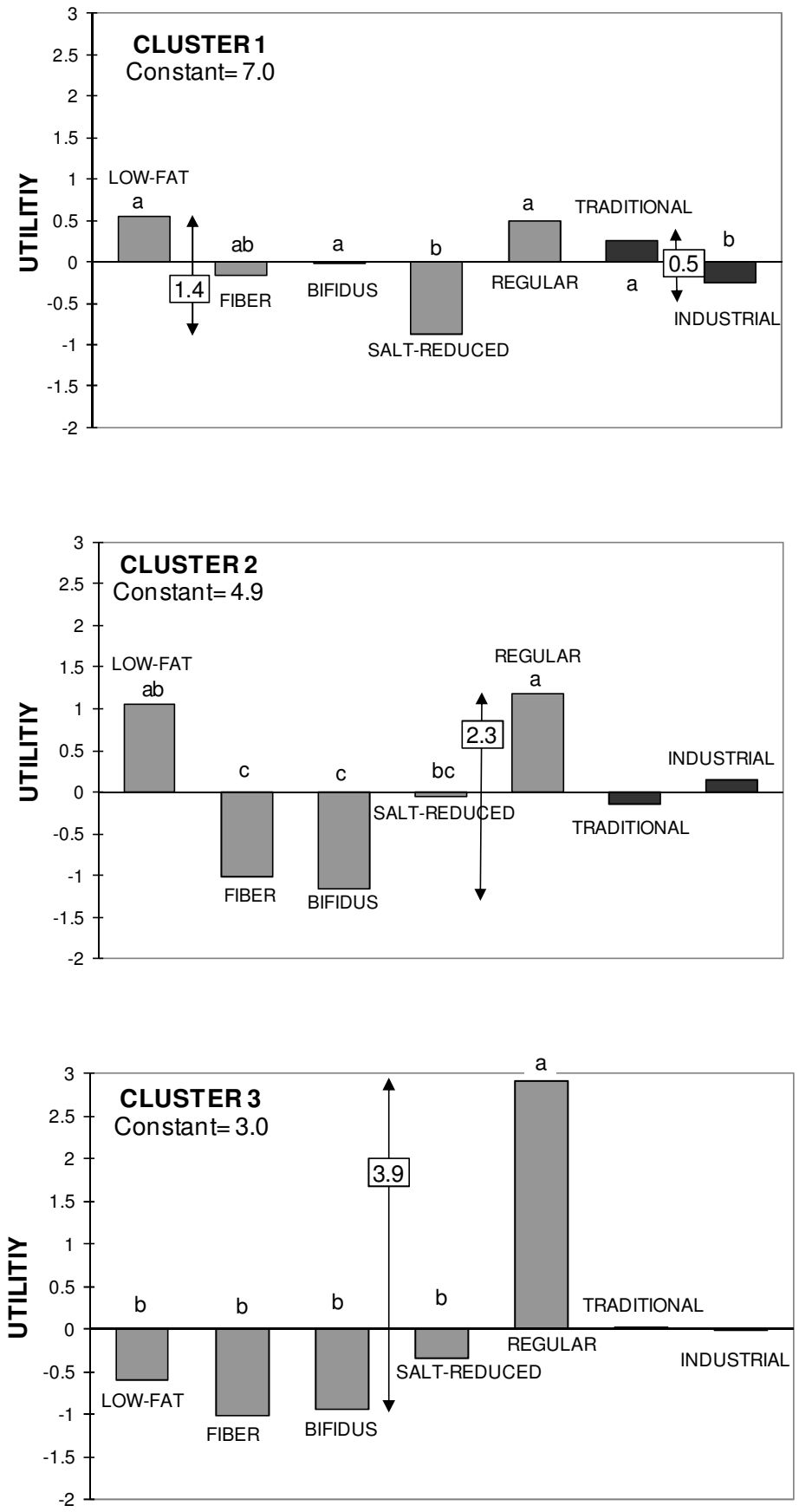

Figure 3. Mean utility values of the studied characteristic for Dambo cheese and for each consumers cluster. For each factor (health benefit $\square$; processing type $\square$ ), values not sharing letters are significantly different $(\mathrm{p} \leq 0.05)$. 


\section{Consumer characteristics affecting response to cheeses with health benefits.}

Some consumer characteristics such as gender, age and personal attitude toward a healthy diet can influence consumer responses toward a product with health benefits. In the present study, consumer distribution according gender, age and the interest in a healthy diet in each cluster was analyzed for both spreadable and Dambo cheese (Tables 7 and 8). For both, the consumers willing to consume cheese with health benefits (cluster 1) showed a higher percentage of women (cluster 3) (Tables 7 and 8). That is in agreement with previous studies reporting that acceptability of functional foods varies with gender (Ares \& Gámbaro, 2007) and that, in general, women are more interested in eating healthily than men (Steptoe, Pollard, \& Wardle, 1995; Stewart-Knox et al. 2007, Johansen, Næs, \& Hersleth, 2011, Urala \& Lähteenmäki, 2004). Differences in consumer behavior were not related with the variation in age. The relationship between the different consumer responses and their attitude towards a healthy diet was studied. In a previous work (unpublished data), the dimensionality of the responses to the General Health Interest Questionnaire was studied, showing that for these Uruguayan consumers, the items corresponded to two different dimensions. The first dimension related to the theoretical importance that consumers gave to the diet-health relationship (items 2, 4, 5 and 6; Table 2) and a second dimension related to their actual eating behavior (items 1, 3,7 and 8; Table 2). According to these two dimensions, consumers were classified into three groups: high, medium and low interest. The group of consumers with high interest $(n=55)$ were those that considered the diet-health relationship to be important (sum of scores in dimension $1>14$ ) and consequently ate healthily (sum of scores on dimension $2>14)$. The group of consumers who showed medium interest $(n=64)$ were those that did not follow a healthy diet (sum of scores on dimension $2 \leq$ 14), despite considering the diet-health relationship important (sum of scores in dimension $1>14)$. Finally, consumers with low interest $(n=43)$ were those that did 
not consider important the relation diet-health and did not eat healthily (sum of scores $\leq 14$ for the two dimensions). As can be observed in Tables 7 and 8 , the distribution of consumers with high and with low interest in a healthy diet significantly varied among clusters. For both types of cheeses, the percentage of consumers with low interest were significantly higher in cluster 3 , who were those willing to consume only regular cheese. The percentage of consumers highly concerned with a healthy diet was significantly higher for cluster 1 , which included consumers willing to accept health claims for cheese.

Table 7. Distribution of consumers (\%) on clusters for spreadable cheese, according to gender, age and interest on healthy diet. Difference among proportions test, $\chi^{2}$ and probability ( $\mathrm{p}$ ) values.

\begin{tabular}{llccccc}
\hline Characteristics & Level & Cluster 1 & Cluster 2 & Cluster 3 & $\chi^{2}$ & $\mathrm{p}$ \\
\hline \multirow{2}{*}{ Gender } & Male & $28^{\mathrm{a}}$ & $37^{\mathrm{ab}}$ & $57^{\mathrm{b}}$ & 9.3 & 0.011 \\
& Female & $72^{\mathrm{b}}$ & $63^{\mathrm{ab}}$ & $43^{\mathrm{a}}$ & & \\
& & & & & & \\
\multirow{2}{*}{ Age } & 18 to 40 years old & 66 & 78 & 55 & 5.9 & 0.051 \\
& 41 to 66 years old & 34 & 22 & 45 & & \\
\multirow{2}{*}{$\begin{array}{l}\text { Interest in } \\
\text { health }\end{array}$} & High & $47^{\mathrm{b}}$ & $22^{\mathrm{a}}$ & $30^{\mathrm{ab}}$ & 10.2 & 0.006 \\
& Medium & $41^{\mathrm{a}}$ & $41^{\mathrm{b}}$ & 36 & 0.3 & 0.883 \\
& Low & $12^{\mathrm{a}}$ & $37^{\mathrm{b}}$ & $34^{\mathrm{b}}$ & 10.8 & 0.004 \\
\hline
\end{tabular}

Within each row, percentage values followed by different letters are significantly different $(\mathrm{p} \leq 0.05)$. 
Table 8. Distribution of consumers (\%) on clusters for Dambo cheese, according to gender, age an interest on healthy diet. Difference among proportions test, $\chi^{2}$ and probability $(\mathrm{p})$ values.

\begin{tabular}{|c|c|c|c|c|c|c|}
\hline Characteristics & Level & Cluster 1 & Cluster 2 & Cluster 3 & $\chi^{2}$ & $\mathrm{p}$ \\
\hline \multirow{2}{*}{ Gender } & Male & $26^{\mathrm{a}}$ & $41^{\mathrm{ab}}$ & $58^{\mathrm{b}}$ & 9.1 & 0.011 \\
\hline & Female & $74^{b}$ & $59^{\mathrm{ab}}$ & $42^{\mathrm{a}}$ & & \\
\hline \multirow{2}{*}{ Age } & 18 to 40 years old & 77 & 63 & 55 & 5.4 & 0.068 \\
\hline & 41 to 66 years old & 23 & 37 & 45 & & \\
\hline \multirow{3}{*}{$\begin{array}{l}\text { Interest in a } \\
\text { healthy diet }\end{array}$} & High & $44^{b}$ & $31^{\mathrm{ab}}$ & $19^{\mathrm{a}}$ & 6.0 & 0.049 \\
\hline & Medium & 41 & 40 & 32 & 0.7 & 0.700 \\
\hline & Low & $15^{\mathrm{a}}$ & $29^{\mathrm{ab}}$ & $49^{b}$ & 11.9 & 0.003 \\
\hline
\end{tabular}

Within each row, percentage values followed by different letters are significantly different $(\mathrm{p} \leq 0.05)$.

\section{Understanding how health benefits affect willingness to purchase cheese}

In this second part of the study, laddering technique was used to provide information about consumers' motivations for purchasing or rejecting cheeses with different health benefits. Dambo cheese was the product considered in this part of the study. According to the ranking results, the order of choice of labels significantly varied among cheeses with different health benefits (FFriedman (4) $=34.2, \mathrm{p}<0.0001)$. The first position of choice was taken by the label indicating low-fat, followed by the regular cheese, and the fiber-enriched label, and in the last position were the labels of bifidus-containing and salt-reduced cheeses (Figure 4). All participants indicated that they would by the regular cheese because they thought it would taste good and be pleasurable to eat. Most of them indicated that they would buy the low-fat cheese and less than half indicated that would buy cheese with the other benefits (salt-reduced, fiber-enriched and with bifidus) (Figure 4). 


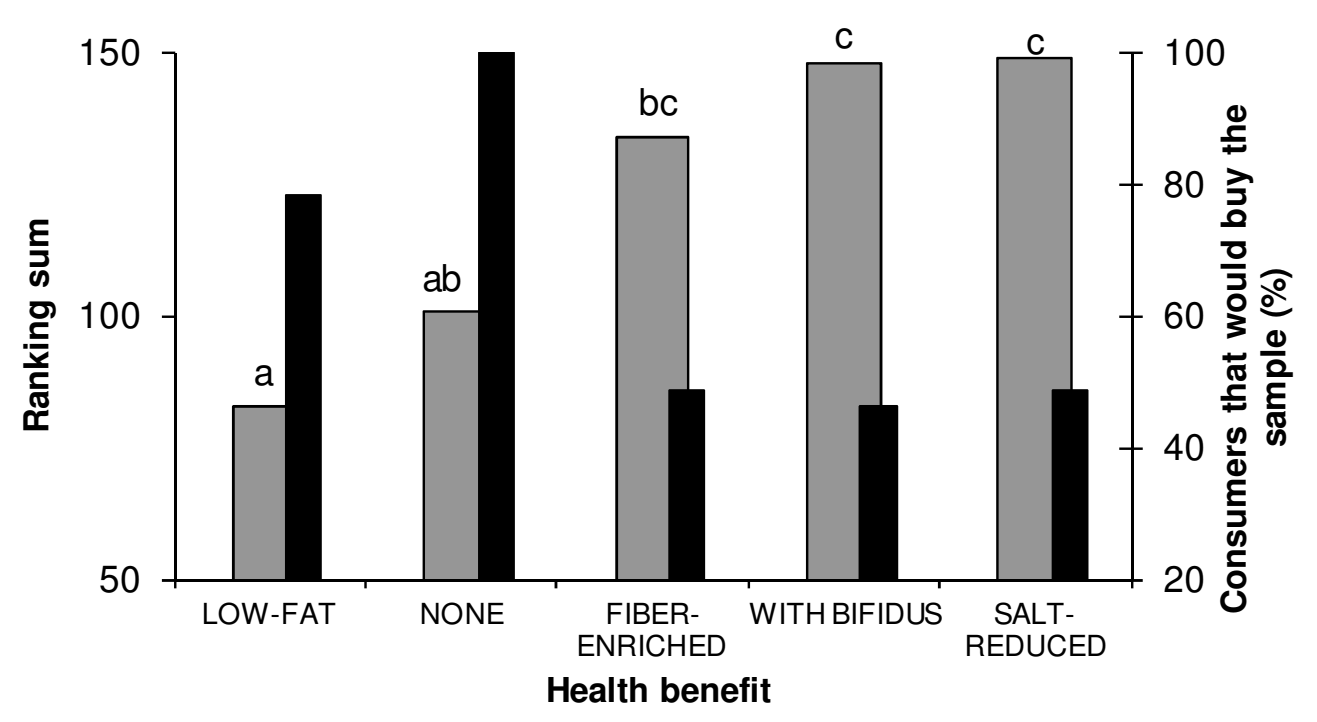

Figure 4. Order of consumers choice (from first to last) of cheese labels with different health benefit (rank sum values, $\square$ ) and percentage of consumers that would buy the sample ( $\square$ ) according to its benefit).

Participants' responses indicating the reasons for buying, or not buying, each type of cheese were analyzed and summarized, keeping the MEC theory abstraction levels. Overall, 4 attributes (corresponding to the four health benefits), 14 consequence codes and 5 value codes were elicited from all the responses, considering both the reason for buying and for not buying the samples. A total of 20 ladders were obtained. The Hierarchical Value Map (HVM) with the reasons for buying cheeses is shown in Figure 5. In general, behind the choice of cheeses with a health benefit consumers wanted look more attractive and achieve a better quality of life. Many participants would purchase low-fat cheeses but gave different reasons. Most of them did not want to gain weight. For these people it was important to look good and they associated this condition with weight control. There were also people that would buy low-fat 
cheese looking for a better quality of life, either because they had high levels of cholesterol and they wanted to control the fat intake, or just because they wanted to prevent certain diseases. Similarly, some participants indicated that they would buy the salt-reduced cheese to reduce salt intake, either because they had hypertension or just because they considered that was good to prevent diseases. The reasons indicated by participants interested in fiber-enriched cheese were the prevention of diseases or to improve constipation. Participants interested in bifidus and some people interested in fiber, indicated that they would buy these cheeses because they were good for health, even if they did not really know their mechanisms of action.

On the other hand, the final reason participants gave for not buying cheeses with health benefits were the expected lack of pleasure and distrust of the claimed health benefit. Pleasure was the basic value that people look for through consumption of regular cheese and it was also the most frequently mentioned reason for rejecting cheeses with changes in composition. For salt-reduced, lowfat and fiber-enriched cheeses some participants expected them to taste bad and were not willing to compromise pleasure to obtain a health benefit they considered they did not need. Some of the participants were interested in fiber, bifidus and low-fat, but preferred to obtain them from other kinds of product and not from cheese. Finally, bifidus and fiber were the health benefits that caused people to distrust the product. The lack of knowledge about the effects of fiber and bifidus on health led these people to doubt their possible benefits.

In summary, the main reasons why Uruguayan participants would buy cheese with health benefits were to achieve a better quality of life and to look attractive. But, they were also concerned about both the pleasure and the real effect on health that the product could provide. Accordingly, Ares et al. (2008) found that the main reason why Uruguayan consumers chose among different benefits in yogurt were healthiness and pleasure. The same basic motivations for buying health products were observed for consumers from other countries, like the 
United States, Denmark and Norway (Johansen et al. 2011) and Italy (Annunziata \& Vecchio, 2011). Urala and Lähteenmäcki (2004) found that Finnish consumers stated the same motivations for choosing among functional food alternatives but also gave other reasons, like convenience, price and familiarity.

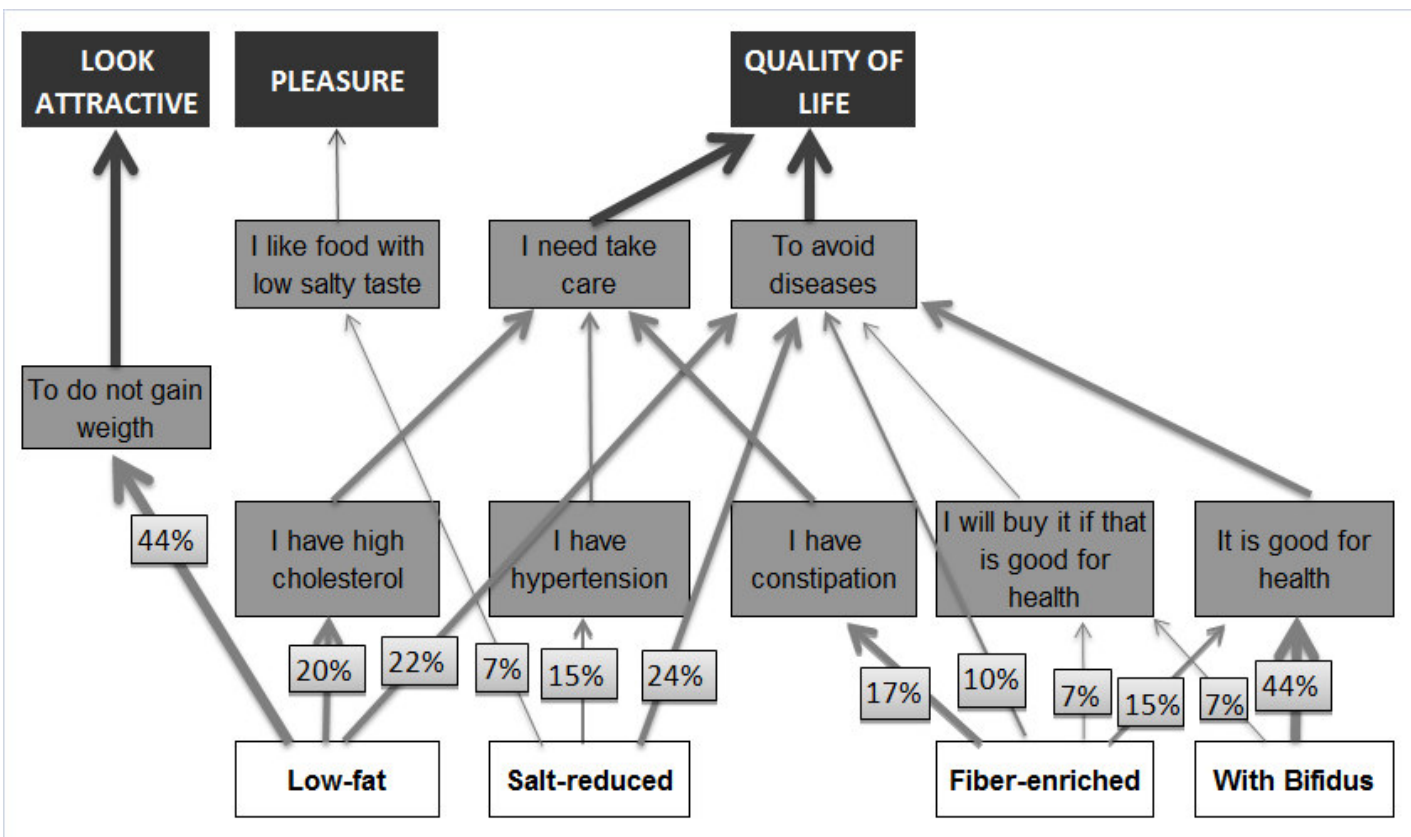

Figure 5. Laddering plot of consumer motivations for buying cheese with health benefits. 


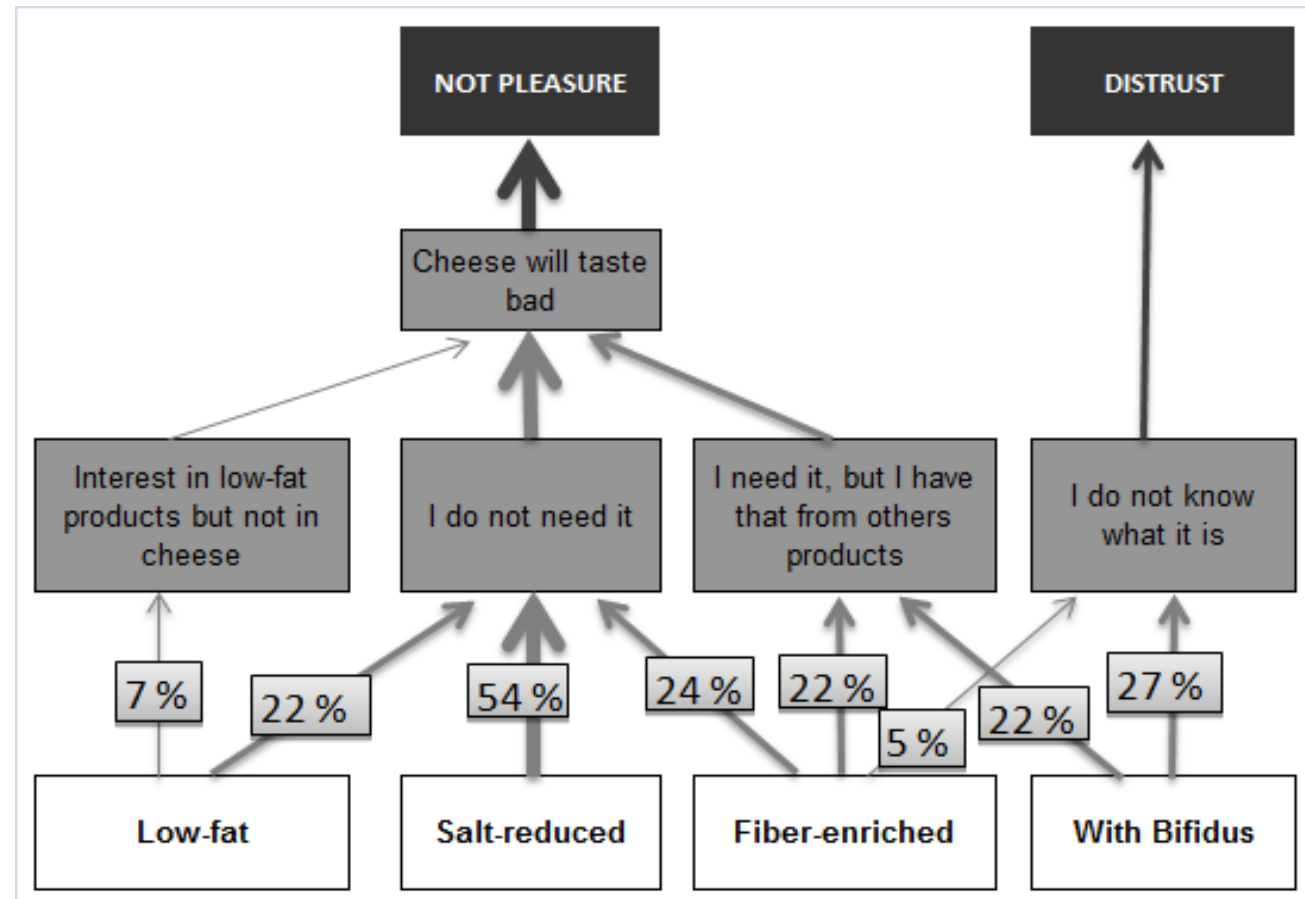

Figure 6. Laddering plot of consumer motivations for not buying cheeses with health benefits.

\section{CONCLUSION}

The interest of Uruguayan consumers in spreadable and Dambo cheese significantly varied when a health benefits is indicated. In general, health claims did not cause an increase in Uruguayan consumers' interest over the regular product. However, around $40 \%$ of consumers were willing to consume cheeses with certain health benefits; low-fat cheese in particular was the most appealing to consumers, especially in the case of spreadable cheese. Behind the choice of cheeses with a health benefit, consumers wanted look more attractive and achieve a better quality of life. Meanwhile, expected lack of pleasure and 
distrust were the basic reasons people gave for rejecting a cheese with health benefits.

\section{ACKNOWLEDGMENTS}

The financial support of MICINN, Spain (Tarrega's contract within the Juan de la Cierva Programme) and financial support of LATU, Uruguay for Arcia's stay at IATA, are all gratefully acknowledged.

\section{REFERENCES}

Annunziata, A. \& Vecchio, R. (2011). Functional foods development in the European market: A consumer perspective. Journal of Functional Food, 3, 223-228.

Ares, G. \& Gámbaro, A. (2007). Influence of gender, age and motives underlying food choice on perceived healthiness and willingness to try functional foods. Appetite, 49, 148-158.

Ares, G., Giménez, A. \& Deliza, R. (2010). Influence of three non-sensory factors on consumer choice of functional yogurts over regular ones. Food Quality and Preference, 21, 361-367.

Ares, G., Giménez, A. \& Gámbaro, A. (2008). Influence of nutritional knowledge on perceived healthiness and willingness to try functional foods. Appetite, 51, 663-668.

Awaisheh, S. S. (2011). Development of probiotic soft cheese manufactured using goat's milk with the addition of thyme. Milchwissenschaft, 66, 5154. 
Bruhn, C.M., Cotter, A., Diaz-Knauf, K., Sutherlin, J., West, E., Wightman, N., Williamson, E., \& Yaffee, M. (1992). Consumer attitudes and market potential for foods using fat substitutes. Journal Dairy Science, 75, 25692577.

Caporale, G., \& Monteleone, E. (2001). Effect of expectations induced by information on origin and its guarantee on the acceptability of a traditional food: olive oil. Sciences des Aliments, 21, 243-254.

Crossley, M., \& Khan, S. (2001). Motives underlying food choice: dentist, porters and dietary health promotion. British Dental Journal, 191, 198202.

Drewnowski, A., Aggarwal, A., Hurvitz, P., Hastert, T., \& Moudon, A.V. (2010). The Perceived Importance of a Healthy Diet Predicts Retail Outlet Choice, Food Purchases and Body Weight. Journal of the American Dietetic Association, 110, A13.

Fritzen-Freire, C. B., Müller, C. M. O., Laurindo, J. B., \& Prudêncio, E. S. (2010). The influence of Bifidobacterium Bb-12 and lactic acid incorporation on the properties of Minas Frescal cheese. Journal of Food Engineering, 96, 621-627.

Guerrero, L., Colomer, Y., Guàrdia, M.D., Xicola, J., \& Clotet, R. (2000). Consumer attitude towards store brands. Food Quality and Preference, 11, 387-395.

Guerrero, L., Guàrdia, M. D., Xicola, J., Verbeke, W., Vanhonacker, F., Zakowska-Biemans, S., Sajdakowska, M., Sulmont-Rossé, C., Issanchou, S., Contel, M., Scalvedi, M. L., Granli, B. S., \& Hersleth, M. (2009). Consumer-driven definition of traditional food products and innovation in traditional foods. A qualitative cross-cultural study. Appetite, 52, 345-354.

Gutman, J. (1982). A means-end chain model based on consumer categorization processes. Journal of Marketing, 46, 60-72. 
Guttierres, R. \& Barreto, A. L. (2010). Characterization of Requeijao cheese potentially prebiotic by the addition of inulin and soy protein. Boletim do Centro de Pesquisa e Processamento de Alimentos, 28: 289-302.

Johansen, S. B., Næs, T., \& Hersleth, M. (2011). Motivation for choice and healthiness perception of calorie-reduced dairy products. A cross-cultural study. Appetite, 56, 15-24.

Levy, K. J. (1975). Large-sample pair-wise comparisons involving correlations, proportions, or variances. Psychological Bulletin, 82(2), 174-176.

Lindeman. M. \& Stark, K. (1999). Pleasure, pursuit of health, or negotiation of identity? Personality correlates of food choice motives among young and middle-aged women. Appetite, 33, 141-161.

Meilgaard, M., Civille, G. \& Carr, B. (1999). Sensory Evaluation Techniques. Florida: CRC Press, pp. 25-30.

Menrad, K. (2003). Market and marketing of functional food in Europe. Journal of Food Engineering, 56, 181-188.

Moskowitz, H., Beckley, J., \& Minkus-McKenna, D. (2004). Use of conjoint analysis to assess web-based communications on functional foods. Appetite, 43, 85-92.

Moskowitz, H., \& Silcher, M. (2006). The applications of conjoint analysis and their possible uses in Sensometrics. Food Quality and Preference, 17, 145-165.

Noronha, N., O'Riordan, E. D., \& O’Sullivan, M. (2007). Replacement of fat with functional fibre in imitation cheese. International Dairy Journal, 17, 1073-1082.

Reynolds, T. J., \& Gutman, J. (1988). Laddering theory, method, analysis, and interpretation. Journal of Advertising Research, 28, 11-31.

Rodrigues, D., Rocha-Santos, T. A. P., Pereira, C. I. Gomes, A. M., Malcata, F, X., \& Freitas, A. C. (2011). The potential effect of FOS and inulin upon 
probiotic bacterium performance in curdled milk matrices. LWT - Food Science and Technology, 44, 100-108.

Roininen, K., Lähteenmäki, L., \& Tuorila, H. (1999). Quantification of Consumer Attitudes to Health and Hedonic Characteristics of Foods. Appetite, 33, 71-88.

Shepherd, R. (1989). Factors influencing food preferences and choice. In: Handbook of the Psychobiology of Human Eating (Ed. R. Shepherd), p. 3-14. John Wiley \& Sons Ltd, Chichester.

Sijtsema, S. J., Backus, G. B. C., Linnemann, A. R. \& Jongen, W. M. F. (2004). Consumer orientation of product developers and their product perception compared to that of consumers. Trends in Food Science \& Technology, $15,489-497$.

Siró, I., Kàpolna, E., Kàpolna, B. \& Lugasi, A. (2008). Functional food. Product development, marketing, and consumer acceptance-A review. Appetite, 51, 456-467.

Sørensen, E. B. \& Askegaard, S. (2007). Laddering: how (not) to do things with words. Qualitative Marketing Research: An International Journal, 10, 6377.

Steptoe, A., Pollard, T. M. \& Wardle, J. (1995). The development of a measure of the motives underlying the selection of food: the Food Choice Questionnaire. Appetite, 25, 267-284.

Stewart-Knox, B. J., Vaz De Almeida, M. D., Parr, H., Pinhao, S., Bunting, B., \& Gibney, M. (2007). Consumer uptake of functional foods in Europe. International developments in science \& health claims, ILSI international symposium on functional foods in Europe.

Trichopoulou, A., Soukara, S., \& Vasilopoulou, E. (2007). Traditional foods: a science and society perspective. Trends in Food Science \& Technology, $18,420-427$. 
Urala, N., \& Lähteenmäki, L. (2004). Attitudes behind consumers' willingness to use functional foods. Food Quality and Preference, 15, 793-803.

Urala, N., \& Lähteenmäki, L. (2007). Consumers“ changing attitudes towards functional foods. Food Quality and Preference, 18, 1-12.

van Kleef, E., van Trijp, H. C. M., Luning, P., \& Jongen, W. M. F. (2002). Consumer-oriented functional food development: how well do functional disciplines reflect the 'voice of the consumer'? Trends in Food Science \& Technology, 13, 93-101.

Villegas, B. Carbonell, I. \& Costell, E. (2008). Effects of product information and consumer attitudes on responses to milk and soybean vanilla beverages. Journal of the Science of Food and Agriculture, 88: 24262434.

Wilcock, A., Pun, M., Khanona, J., \& Aung, M. (2004). Consumer attitudes, knowledge and behaviour: a review of food safety issues. Trends Food Science \& Technology, 15, 56-66. 



\section{CAPÍTULO 2}

\section{Sensory properties and acceptance of Uruguayan low-fat cheeses}

Enviado a la revista Dairy Science \& Technology 



\title{
SENSORY PROPERTIES AND ACCEPTANCE OF URUGUAYAN LOW-FAT CHEESE
}

\author{
PATRICIA ARCIA ${ }^{1,2}$, ANA CURUTCHET ${ }^{2}$, ELVIRA COSTELL ${ }^{1}$, AMPARO \\ TÁRREGA ${ }^{1}$ \\ ${ }^{1}$ Physical and Sensory Properties Laboratory. Instituto de Agroquímica y Tecnología de Alimentos \\ (CSIC), Avda. Agustín Escardino, 7. 46980 Paterna (Valencia), Spain. \\ ${ }^{2}$ Laboratorio Tecnológico del Uruguay. Av. Italia 6201, C.P. 11500. Montevideo, Uruguay.
}

\begin{abstract}
In Uruguay, "queso magro" is a variety of cheese with low fat content. Due to health and overweight concerns, there is an increasing interest of consumers for this type of cheese. To increase the success of the product in the market is interesting to identify the sensory characteristics that influence consumer's acceptability. The objective of this work was to study the variability in sensory properties of commercial Uruguayan low-fat cheeses and to establish whether there is a relationship with its acceptability. Six samples differing in composition and instrumental texture were studied. The sensory properties of these cheeses were evaluated by a trained panel and subsequently sample acceptability was evaluated by 84 consumers. Uruguayan low-fat cheeses were characterized by having a soft odor and taste, intermediate firmness, medium-high elasticity and low friability. Samples mainly differed in their texture attributes, firmness and elasticity though slight variations were observed for flavor attributes. Consumers' liking scores varied widely among samples. According to the analysis of the relationship among sensory properties and acceptance, flavor attributes like odor and taste intensity, bitterness and aftertaste were those that dictated the differences in acceptance. The knowledge of the sensory
\end{abstract}


characteristics that drives consumer liking of product is useful to develop products with high consumer acceptance.

Key words: low fat, cheese, sensory profile, acceptability

\section{INTRODUCTION}

Fat reduction in the diet is important based on scientific evidence linking high fat diets to coronary heart disease and certain types of cancer (Woteki and Thomas 1993). This association has led to increasing consumer awareness and an important increase in the supply of, and demand for, low-fat foods, including low-fat cheeses. The concept of low-fat cheese manufacture is not a new idea; the emphasis on controlling caloric intake, especially in developed countries, has largely been responsible for the growth in low-fat cheese markets in the past 20 years (Mistry 2001). Although low-fat cheese helps reduce fat and calorie intake, the removal of fat causes changes in cheese flavor and texture. Originally, lowfat cheeses, launched in the early 1990s, were met with general dissatisfaction and consumers were not willing to sacrifice the cheese flavor they desired to avoid a few grams of fat (Drake and Swanson 1995). Furthermore cheese texture is strongly affected by fat reduction (Drake and Swanson 1995; Yates and Drake 2007). Gwartney et al. (2002) reported that the majority of reduced-fat cheeses were characterized by having higher chewiness, hardness, waxiness, fracturability and springiness. Brown et al. (2003) and Yates and Drake (2007) confirmed these findings and showed that reduced-fat cheeses were firmer and springier, and displayed lower adhesiveness and cohesiveness compared to fullfat cheeses. The low hedonic expectation generated in consumers by fat reduction has been the major obstacle to the success of low-fat versions of already well-known cheese varieties (Mistry 2001). However, the strategies 
consumers adopt to reduce fat in their diets are not straightforward and, rather than derivatives of existing products, consumers prefer low-fat products considered "new" or start to consume products traditionally known as having low fat content. This is the case of "queso magro" in Uruguay, which is a variety of cheese with low fat content (10-25\%, according to RBN Decree No. 315/94) and, due to both health and overweight concerns, there is an increasing demand for this product. This presents an interesting opportunity for manufacturers to launch a potentially successful product, providing they develop a low-fat cheese with the sensory properties consumers want. Therefore, is important to know how the variations in sensory properties affect acceptability and to determine which sensory characteristics drive consumer liking of this product (ten Kleij and Musters 2003). The most usual procedure to do this is to relate consumer preference ratings with the sensory profile of samples evaluated by a selected and trained panel. Trained assessors objectively provide a quantitative description of the perceived sensory characteristics of a product (Jelinek 1985).

The objective of this work was to study the variability in sensory properties of Uruguayan commercial low-fat cheeses and to establish how this related to its acceptability.

\section{MATERIALS AND METHODS}

\section{Samples}

Six Uruguayan commercial low-fat cheeses (coded from A to F) were evaluated. The selection criteria were based on a previous analysis of the commercial product range and on their availability in almost all big supermarkets in Montevideo. The samples were purchased from the market, taking into account expiry dates, and were stored under refrigeration $\left(4 \pm 1^{\circ} \mathrm{C}\right)$ until analyzed. 


\section{Chemical Analysis}

The fat content of samples was analyzed using the Van Gulik method (FIL 222:2008/ISO 3433:2008). The moisture content of cheeses was determined using the oven method ( $9 \mathrm{~h}$ at $102{ }^{\circ} \mathrm{C}$; FIL 4:2004/ISO 5534:2004). The protein content of cheeses was determined using the Kjeldahl method (FIL 202:2001/ISO 8968-2:2001). Salt content (Sodium Chloride) of cheese samples was determined using the Chloride method (FIL 88:2006/ISO 5943:2006). Two replicates of each sample were analyzed.

\section{Instrumental Texture Analysis}

Texture Profile Analysis (TPA) was performed on the six samples, using a TAXT2i (Stable Micro Systems Ltd., Godalmingel, UK). For the tests, samples at $4 \pm 1^{\circ} \mathrm{C}$ were cut and equilibrated at room temperature $\left(20 \pm 1^{\circ} \mathrm{C}\right)$ for $30 \mathrm{~min}$ before measurements were taken. For TPA analysis, samples were cut into cylindrical pieces of $17 \mathrm{~mm}$ in diameter and $20 \mathrm{~mm}$ in height and were compressed using two uniaxial compression cycles. Test conditions were: P/75 aluminum cylinder probe $(75 \mathrm{~mm}$ diameter); pre-test speed $5 \mathrm{~mm} / \mathrm{s}$; test speed $5 \mathrm{~mm} / \mathrm{s}$; post-test speed $5 \mathrm{~mm} / \mathrm{s}$; compression (strain) 35\%; time pause $5 \mathrm{~s}$. From the Force/Time curves, firmness, springiness, cohesiveness, chewiness and resilience were obtained. For this analysis three replicates of each sample were analyzed. Data collection and calculations were done using the Texture Expert Exceed Version 2.52 .

\section{Sensory analysis}

Sensory properties of cheeses were evaluated by a trained panel and the acceptability of samples was evaluated by consumers. Both analyses were carried 
out in a standardized test room (ISO 8589, 2007). Cheese samples were cut into sticks with approximate dimensions of $1.5 \times 1.5 \mathrm{~cm}$ and $5 \mathrm{~cm}$ in height, served at $15-20{ }^{\circ} \mathrm{C}$ in transparent plastic dishes, coded with three digit random numbers. Mineral water was provided for mouth-rinsing.

\section{Selection and training of assessors}

Sixteen candidates, between 28 and 50 years old (9 women and 7 men) participated in the selection and training of the cheese sensory panel. Candidates were selected following the ISO 22935-1:2009 guidelines. The assessors' discrimination ability for the four basic tastes (acid, salt, sweet and bitter) were evaluated in preliminary triangle tests and ranking tests in two different medium (water and ricotta cheese) (Gallerani et al. 2000). All candidates achieved high percentages of success in all these tests. In the next stage, they were trained to recognize the cheeses attributes. Texture and flavor descriptors were considered in separate sessions. An initial list with descriptors used by other authors (Montero et al. 2005; Lavanchy et al. 1993) was presented to the candidates. By open discussion among panel leader and candidates the final list of terms was established (Table 1). Reference products were used to fix the anchors on the scale (Lavanchy et al. 1993; ISO 22935-1:2009). The following six sessions were used to train assessors in the use of the 0-7 unstructured line scale for all attributes (Table 1). In these sessions candidates evaluated three cheese samples. At the end of each session, the panel leader and the candidates discussed the individual results obtained in order to recognize deviations and correct them. Finally, three sessions were performed to evaluate discrimination capability and repeatability of candidates. To do so, they evaluated four cheese samples in triplicate. During training sessions, discriminatory capability and repeatability for each candidate were analyzed. To do so, results obtained by two-way ANOVA (sample and session) for each attribute and each assessor was used. An assessor was considered to be repeatable for an attribute if Fsession value was not 
significant $(\mathrm{p}<0.05)$ and was considered to discriminate among samples if Fsample was significant ( $\mathrm{p}>0.5$ ). According to these criteria, twelve assessors with good discriminatory capacity (Fsample not significant for less than four attributes) and adequate repeatability (Fsession not significant in more than five attributes) were considered to be part of the final panel.

\section{Sensory profile}

The six commercial low-fat cheeses were profiled in duplicate by the trained panel over four sessions, evaluating three samples per session. Each of the assessors evaluated the intensity of the fifteen attributes for each cheese sample.

\section{Consumer acceptance}

Eighty-four consumers between 18 and 66 years of age (54\% women and 46\% men), evaluated the overall acceptability of the six samples in one session using a 9-point hedonic scale ( 1 = "I dislike extremely, $9=$ " I like extremely). The presentation order of samples was equilibrated among consumers following a Williams design (MacFie et al., 1989).

\section{Data analysis}

One way analysis of variance (ANOVA) was performed on chemical and texture parameters in order to study the variability among cheese samples. On acceptability data a mixed model of ANOVA was applied. Significance of differences between samples was determined by the Tukey test $(\alpha \leq 0.05)$. Data from the evaluation of the six cheeses (12 assessors, 15 attributes, 6 samples, 2 replicates) were analyzed for each attribute with two-way ANOVA (assessors and samples) with interaction. Concordance for each assessor was studied analyzing the interaction effect. In order to identify the assessors with low concordance with the rest of the panel, the approach proposed by Carbonell et al. 
(2007) was followed, consisting of estimating the contribution of each panelist to the total sum of squares of the interaction (SSI). According to the increasing contribution values, rank orders were assigned to each panelist, and for each of them the sum of rank orders of the fifteen attributes was computed. Principal Component Analysis (PCA) was applied to the correlation matrix of the average values of the sensory attributes for low-fat cheese samples. Relationships between the sensory attributes and consumer acceptability were established by Partial Least Square (PLS) regression. Analyses were performed using XLSTAT Version 2011 (Addinsoft 1995-2010, France). 
Table 1. List of attributes, definition and anchors used during training sessions

\begin{tabular}{|c|c|c|c|}
\hline Attribute & Definition & Scale Level & $\begin{array}{c}\text { Reference product and } \\
\text { intensity }\end{array}$ \\
\hline $\begin{array}{l}\text { Odor } \\
\text { intensity }\end{array}$ & $\begin{array}{l}\text { Strength of the stimulus perceived } \\
\text { above the serving of cheese, either } \\
\text { directly as we approach it, or when we } \\
\text { break into two near the nose }\end{array}$ & $\begin{array}{l}\text { Not detected } \\
\text { to High }\end{array}$ & $\begin{array}{l}\text { Water }=0 \\
\text { Colonia cheese }(*)=4 \\
\text { Hard cheese }(\text { parmesan })=6\end{array}$ \\
\hline $\begin{array}{l}\text { Firmness } \\
\text { tactile }\end{array}$ & $\begin{array}{l}\text { Resistance of the sample to be } \\
\text { compressed by the forefinger }\end{array}$ & $\begin{array}{l}\text { Weak to } \\
\text { High }\end{array}$ & $\begin{array}{l}\text { Watermelon }=1 \\
\text { Olive }=4 \\
\text { Candy } / \text { carrot }=7\end{array}$ \\
\hline $\begin{array}{l}\text { Firmness in } \\
\text { mouth }\end{array}$ & $\begin{array}{l}\text { Resistance of the samples to a very } \\
\text { slight opening and shutting of the jaws }\end{array}$ & $\begin{array}{l}\text { Weak to } \\
\text { High }\end{array}$ & $\begin{array}{l}\text { Watermelon }=1 \\
\text { Olive }=4 \\
\text { Carrot }=7\end{array}$ \\
\hline Elasticity & $\begin{array}{l}\text { Ability of a cheese sample to rapidly } \\
\text { regain its initial shape after its } \\
\text { compression and deformation. }\end{array}$ & Low to High & $\begin{array}{l}\text { Soft butter } / \text { raw carrot }=0 \\
\text { Olive }=4 \\
\text { Frankfurter }=7\end{array}$ \\
\hline Friability & $\begin{array}{l}\text { Capacity of a sample to break up into } \\
\text { numerous pieces from the beginning of } \\
\text { mastication }\end{array}$ & $\begin{array}{l}\text { Low to } \\
\text { High }\end{array}$ & $\begin{array}{l}\text { Hardboiled egg white }=1 \\
\text { Muffin }=4 \\
\text { Shortbread/ Alfajor de } \\
\text { maizena) }=7\end{array}$ \\
\hline Solubility & $\begin{array}{l}\text { A sensation which emerges when the } \\
\text { sample melts extremely fast in the } \\
\text { saliva }\end{array}$ & Low to High & $\begin{array}{l}\text { Muffin }=3 \\
\text { Hardboiled egg yolk }=5 \\
\text { Meringue }=7\end{array}$ \\
\hline $\begin{array}{l}\text { Impression } \\
\text { of Humidity }\end{array}$ & $\begin{array}{l}\text { Perception of the degree of humidity in } \\
\text { the sample in the mouth }\end{array}$ & $\begin{array}{l}\text { Dry to } \\
\text { Watery }\end{array}$ & $\begin{array}{l}\text { Meringue } / \text { Gofio }=1 \\
\text { Frankfurter }=5 \\
\text { Tangerine }=7\end{array}$ \\
\hline Adhesivity & $\begin{array}{l}\text { The effort needed for the tongue to } \\
\text { detach a product stuck to the palate }\end{array}$ & Low to High & $\begin{array}{l}\text { Hardboiled egg white }=1 \\
\text { Hardboiled egg yolk }=4 \\
\text { Melted mozzarella }=7\end{array}$ \\
\hline $\begin{array}{l}\text { Taste } \\
\text { intensity }\end{array}$ & $\begin{array}{l}\text { Strength of the stimulus perceived } \\
\text { retronasal when the cheese is placed in } \\
\text { the mouth. }\end{array}$ & $\begin{array}{l}\text { Low to } \\
\text { High }\end{array}$ & $\begin{array}{l}\text { Low fat cheese without salt } \\
\text { added }=1 \\
\text { Colonia cheese }=4 \\
\text { Semi hard cheese }=6\end{array}$ \\
\hline Sweetness & $\begin{array}{l}\text { Describes the taste produced by } \\
\text { aqueous solutions of substances such as } \\
\text { sucrose }\end{array}$ & Low to High & Colonia cheese $=4$ \\
\hline Bitterness & $\begin{array}{l}\text { Describes the taste produced by dilute } \\
\text { aqueous solutions of various } \\
\text { substances such as quinine and caffeine }\end{array}$ & $\begin{array}{l}\text { Not detected } \\
\text { to High }\end{array}$ & Blue cheese $=5$ \\
\hline Salty & $\begin{array}{l}\text { Describes the taste produced by } \\
\text { aqueous solutions of substances such as } \\
\text { sodium chloride. }\end{array}$ & $\begin{array}{l}\text { Not detected } \\
\text { to High }\end{array}$ & $\begin{array}{l}\text { Low fat cheese without salt } \\
\text { added }=0 \\
\text { Semi-hard cheese }=6\end{array}$ \\
\hline Acidity & $\begin{array}{l}\text { Describes the taste produced by dilute } \\
\text { aqueous solutions of most acids bodies }\end{array}$ & $\begin{array}{l}\text { Low to } \\
\text { High }\end{array}$ & Cream cheese $=5$ \\
\hline Spicy & $\begin{array}{l}\text { Describes the trigeminal sensation } \\
\text { manifested in the mouth in the form of } \\
\text { itching }\end{array}$ & $\begin{array}{l}\text { Not detected } \\
\text { to High }\end{array}$ & $\begin{array}{l}\text { Semi hard cheese/ Gruyere } \\
\text { cheese }=6\end{array}$ \\
\hline Aftertaste & $\begin{array}{l}\text { Smell taste sensation that appears after } \\
\text { the elimination of the product and } \\
\text { differs from the sensations perceived } \\
\text { when it was in the mouth }\end{array}$ & Low to High & $\begin{array}{l}\text { Colonia cheese }=4 \\
\text { Semi hard cheese }=6\end{array}$ \\
\hline
\end{tabular}

(*) Colonia cheese is a semi-hard cheese, typical of Uruguay. 


\section{RESULTS}

\section{Cheese composition}

Moisture, fat, sodium and protein content for each cheese sample are shown in Table 2 . The values of all these parameters significantly varied among samples $(\mathrm{p} \leq 0.05)$. In accordance with the National Bromatological Regulation of Uruguay (Reglamento Bromatológico de Uruguay, 1994), cheeses can only be considered as "queso magro" if they have a fat content between 10 and $25 \%$. Although the cheese samples in this study showed an important variation in fat content (from $10.5 \%$ to $21.5 \%$ ), all of them complied with the interval defined by this regulation.

Table 2. Mean values $(n=2)$ for the chemical composition of cheeses.

\begin{tabular}{ccccc}
\hline Sample & Moisture \% & Fat \% & Sodium (mg/100g) & Protein \% \\
\hline A & $51.1^{\mathrm{c}}$ & $13.8^{\mathrm{c}}$ & $306^{\mathrm{c}}$ & $29.4^{\mathrm{b}}$ \\
B & $54.9^{\mathrm{a}}$ & $11.5^{\mathrm{e}}$ & $422^{\mathrm{b}}$ & $28.2^{\mathrm{c}}$ \\
C & $52.3^{\mathrm{b}}$ & $10.5^{\mathrm{f}}$ & $368^{\mathrm{b}}$ & $30.9^{\mathrm{a}}$ \\
D & $50.5^{\mathrm{c}}$ & $13.0^{\mathrm{d}}$ & $556^{\mathrm{a}}$ & $30.9^{\mathrm{a}}$ \\
E & $45.4^{\mathrm{e}}$ & $21.5^{\mathrm{a}}$ & $425^{\mathrm{b}}$ & $28.0^{\mathrm{c}}$ \\
F & $47.8^{\mathrm{d}}$ & $16.3^{\mathrm{b}}$ & $575^{\mathrm{a}}$ & $30.7^{\mathrm{a}}$ \\
\hline
\end{tabular}

For each parameter, values not shearing letters differ significantly $(p=0.05)$.

\section{Texture parameters}

Data obtained from TPA allowed cheese samples to be characterized in terms of firmness, springiness, cohesiveness, chewiness and resilience. For all parameters, the values varied significantly among samples (Table 3). Firmness and chewiness 
showed the most important differences among samples while springiness, cohesiveness and resilience values varied only slightly among samples. The inter-sample differences in firmness could not be explained by differences in composition (Table 3). In most previous studies, the decrease in fat content resulted in an increase in cheese firmness (Hernadez-Morales et al. 2010; SaintEve et al. 2009), but this relationship was not observed in this study, probably because in this case fat reduction was not accompanied by an increase in protein content (Table 3).

Table 3. Texture parameters of cheeses samples obtained from TPA analysis.

\begin{tabular}{lccccr}
\hline Sample & \multicolumn{5}{c}{ TPA } \\
\cline { 2 - 6 } & Firmness (N) & Springiness & Cohesiveness & Chewiness (N) & Resilience \\
\hline $\mathrm{A}$ & $22.7^{\mathrm{C}}$ & $0.92^{\mathrm{B}}$ & $0.87^{\mathrm{ABC}}$ & $18.1^{\mathrm{C}}$ & $0.43^{\mathrm{AB}}$ \\
$\mathrm{B}$ & $7.1^{\mathrm{D}}$ & $0.98^{\mathrm{A}}$ & $0.89^{\mathrm{A}}$ & $6.2^{\mathrm{D}}$ & $0.45^{\mathrm{AB}}$ \\
$\mathrm{C}$ & $7.6^{\mathrm{D}}$ & $0.94^{\mathrm{AB}}$ & $0.88^{\mathrm{AB}}$ & $6.3^{\mathrm{D}}$ & $0.42^{\mathrm{B}}$ \\
$\mathrm{D}$ & $30.6^{\mathrm{B}}$ & $0.95^{\mathrm{AB}}$ & $0.88^{\mathrm{AB}}$ & $25.7^{\mathrm{B}}$ & $0.48^{\mathrm{A}}$ \\
$\mathrm{E}$ & $29.4^{\mathrm{B}}$ & $0.92^{\mathrm{B}}$ & $0.85^{\mathrm{C}}$ & $23.1^{\mathrm{B}}$ & $0.41^{\mathrm{B}}$ \\
$\mathrm{F}$ & $43.8^{\mathrm{A}}$ & $0.95^{\mathrm{AB}}$ & $0.86^{\mathrm{BC}}$ & $35.9^{\mathrm{A}}$ & $0.44^{\mathrm{AB}}$ \\
\hline
\end{tabular}

For each parameter, values not shearing letters differ significantly $(p=0.05)$.

\section{Panel performance}

Twelve assessors evaluated the intensity of the fifteen attributes in the six cheese samples. Concordance among assessors in sample evaluation can be estimated from the interaction sample $\mathrm{x}$ assessor. The results of the two-way ANOVA (assessor, sample) showed that interaction effect was significant in many attributes (eight out the fifteen attributes assessed) (Figure 1.a), indicating a lack of agreement between assessors in their evaluation of these attributes. The 
contribution of each panelist to the total sum of squares of the interaction was calculated and the sum of rank orders of the fifteen attributes was computed for each panelist. Accordingly, assessors 1 and 8 showed the highest rank sum values indicating that they contributed most to the interaction. The two-way ANOVA performed without considering data from these two assessors (Figure 1. b) showed that the number of attributes showing a significant interaction effect was reduced from eight to three. Accordingly, data from these two assessors were not considered in further analysis. 
a)

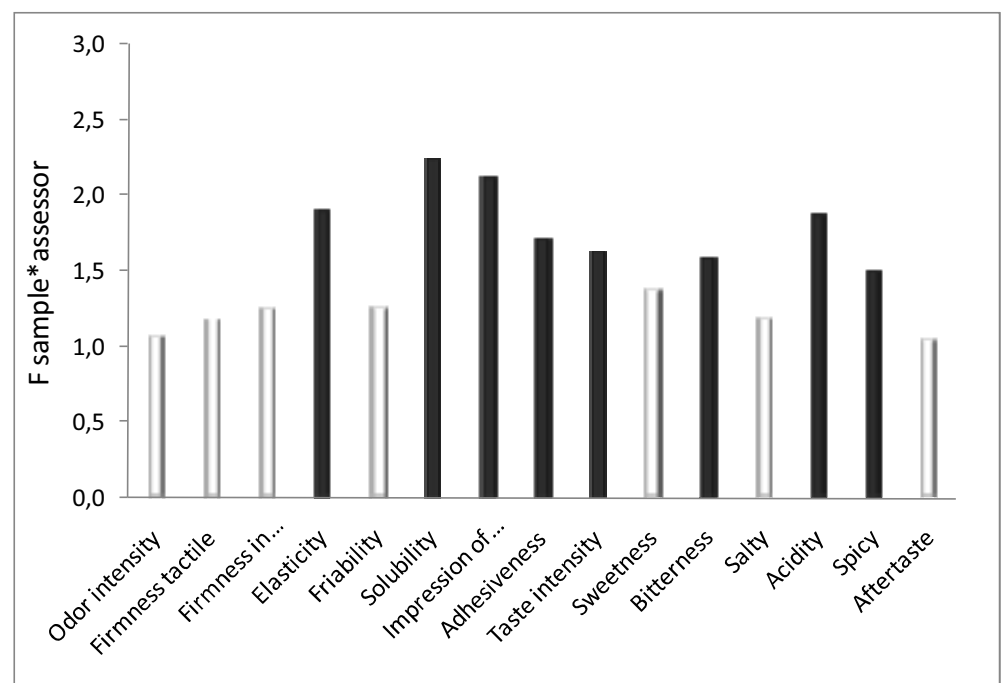

b)

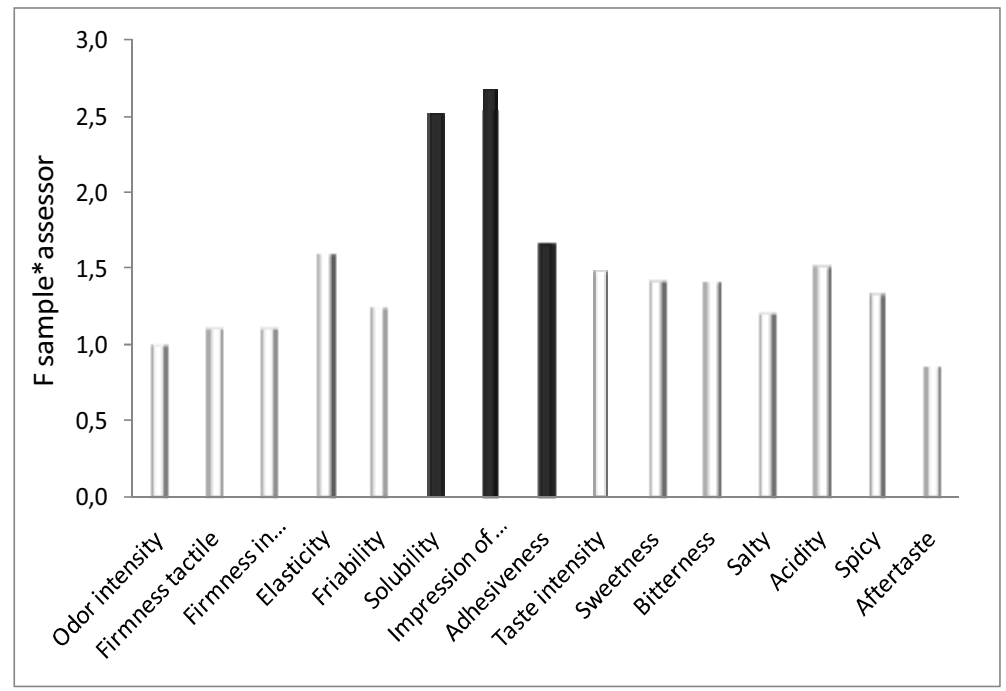

Figure 1. Significance of effect of interaction assessors-sample for each sensory attribute considering data from the twelve initial assessors (a) and the final panel with ten assessors (b). Significant effects are shown in black color $(\mathrm{p}<0.05)$. 


\section{Sensory profile of cheeses}

A mixed model ANOVA was performed on the data of the sensory attributes scored across the six samples (Table 4). According to results, the sample effect was significant for all attributes, even in those (solubility, impression of humidity and adhesiveness) for which the effect of assessors $\mathrm{x}$ sample interaction had been found significant.

Table 5 shows the mean value of each attribute for each cheese sample. According to the results, tactile firmness of the studied cheeses ranged from 2.6 to 4.0 on the $0-7$ intensity scale. Samples B and C presented significantly lower firmness than the remaining samples, which showed intermediate firmness. In the case of firmness evaluated in mouth, data followed the same trend as for tactile firmness. The values obtained for elasticity (4.4 to 5.1), indicated that in general all the studied samples showed a marked elastic quality, although differences in elasticity were perceived among samples. Sample C was the most elastic, while samples D and F showed the lowest elasticity. For friability and solubility, variation among samples followed a similar trend within a narrow range between 2.2 to 2.8 . These values indicate that both friability and solubility in these cheese samples were quite low. Within the range, sample A was the most friable and soluble, whereas sample $\mathrm{C}$ was the least. With respect to the impression of humidity, the values varied from 3.1 to 3.9 and seemed to be related with firmness. The softest samples (C and B) corresponded with the highest values for impression of humidity, while the hardest sample (D) had the lowest value for impression of humidity. The adhesiveness was low for all samples, barely varying from 2 and 2.6. 
Table 4. $F$-ratio values and $p$ values for each attribute according a mixed model of ANOVA.

\begin{tabular}{lcc}
\hline Attribute & $\boldsymbol{F}$ values & $\boldsymbol{p}$ value \\
\hline Odor intensity & 13.22 & $<0.0001$ \\
Firmness tactile & 33.09 & $<0.0001$ \\
Firmness in mouth & 34.26 & $<0.0001$ \\
Elasticity & 7.67 & $<0.0001$ \\
Friability & 11.39 & $<0.0001$ \\
Solubility & 10.49 & $<0.0001$ \\
Impression of humidity & 8.26 & $<0.0001$ \\
Adhesiveness & 3.37 & 0.004 \\
Taste intensity & 18.87 & $<0.0001$ \\
Sweetness & 2.43 & 0.029 \\
Salty & 17.32 & $<0.0001$ \\
Bitterness & 12.58 & $<0.0001$ \\
Acidity & 3.11 & 0.007 \\
Spicy & 5.47 & $<0.0001$ \\
Aftertaste & 6.02 & $<0.0001$ \\
\hline
\end{tabular}


Table 5. Means values of each attribute for each cheese sample (A-F)

\begin{tabular}{lcccccc}
\hline \multicolumn{1}{c}{ Attributes } & $\mathbf{A}$ & $\mathbf{B}$ & $\mathbf{C}$ & $\mathbf{D}$ & $\mathbf{E}$ & $\mathbf{F}$ \\
\hline Firmness tactile & $3.72^{\mathrm{A}}$ & $2.69^{\mathrm{B}}$ & $2.57^{\mathrm{B}}$ & $3.98^{\mathrm{A}}$ & $3.77^{\mathrm{A}}$ & $3.82^{\mathrm{A}}$ \\
Firmness in mouth & $3.72^{\mathrm{AB}}$ & $2.60^{\mathrm{C}}$ & $2.54^{\mathrm{C}}$ & $4.01^{\mathrm{A}}$ & $3.65^{\mathrm{AB}}$ & $3.57^{\mathrm{B}}$ \\
Elasticity & $4.56^{\mathrm{C}}$ & $4.99^{\mathrm{AB}}$ & $5.11^{\mathrm{A}}$ & $4.38^{\mathrm{C}}$ & $4.66^{\mathrm{BC}}$ & $4.39^{\mathrm{C}}$ \\
Friability & $2.82^{\mathrm{A}}$ & $2.42^{\mathrm{BC}}$ & $2.17^{\mathrm{C}}$ & $2.54^{\mathrm{AB}}$ & $2.45^{\mathrm{BC}}$ & $2.71^{\mathrm{AB}}$ \\
Solubility & $2.83^{\mathrm{A}}$ & $2.47^{\mathrm{BC}}$ & $2.18^{\mathrm{C}}$ & $2.61^{\mathrm{AB}}$ & $2.45^{\mathrm{BC}}$ & $2.72^{\mathrm{AB}}$ \\
Impression of & $3.58^{\mathrm{AB}}$ & $3.79^{\mathrm{A}}$ & $3.91^{\mathrm{A}}$ & $3.13^{\mathrm{C}}$ & $3.63^{\mathrm{A}}$ & $3.16^{\mathrm{BC}}$ \\
humidity & $2.49^{\mathrm{A}}$ & $2.58^{\mathrm{A}}$ & $2.44^{\mathrm{AB}}$ & $2.03^{\mathrm{B}}$ & $2.38^{\mathrm{AB}}$ & $2.33^{\mathrm{AB}}$ \\
Adhesiveness & $2.23^{\mathrm{A}}$ & $1.77^{\mathrm{B}}$ & $1.67^{\mathrm{B}}$ & $1.92^{\mathrm{AB}}$ & $1.86^{\mathrm{AB}}$ & $1.69^{\mathrm{B}}$ \\
Odor intensity & $2.59^{\mathrm{A}}$ & $1.88^{\mathrm{BC}}$ & $1.72^{\mathrm{C}}$ & $2.22^{\mathrm{AB}}$ & $1.89^{\mathrm{BC}}$ & $2.30^{\mathrm{A}}$ \\
Taste intensity & $0.72^{\mathrm{AB}}$ & $0.74^{\mathrm{AB}}$ & $0.57^{\mathrm{AB}}$ & $0.59^{\mathrm{AB}}$ & $0.81^{\mathrm{A}}$ & $0.49^{\mathrm{B}}$ \\
Sweetness & $1.98^{\mathrm{A}}$ & $1.31^{\mathrm{B}}$ & $0.92^{\mathrm{B}}$ & $1.74^{\mathrm{A}}$ & $1.30^{\mathrm{B}}$ & $1.89^{\mathrm{A}}$ \\
Salty & $1.14^{\mathrm{B}}$ & $0.92^{\mathrm{B}}$ & $1.84^{\mathrm{A}}$ & $0.94^{\mathrm{B}}$ & $0.90^{\mathrm{B}}$ & $0.82^{\mathrm{B}}$ \\
Bitterness & $1.32^{\mathrm{AB}}$ & $1.12^{\mathrm{AB}}$ & $0.94^{\mathrm{B}}$ & $1.47^{\mathrm{A}}$ & $1.23^{\mathrm{AB}}$ & $1.40^{\mathrm{A}}$ \\
Acidity & $0.84^{\mathrm{A}}$ & $0.54^{\mathrm{ABC}}$ & $0.28^{\mathrm{C}}$ & $0.57^{\mathrm{ABC}}$ & $0.50^{\mathrm{BC}}$ & $0.62^{\mathrm{AB}}$ \\
Spicy & $1.84^{\mathrm{A}}$ & $0.98^{\mathrm{B}}$ & $1.25^{\mathrm{B}}$ & $1.33^{\mathrm{B}}$ & $1.10^{\mathrm{B}}$ & $1.26^{\mathrm{B}}$ \\
Aftertaste & N $_{\text {Within each row, mean values followed by different letters are significantly different }(\mathrm{p} \leq 0.05)}$ &
\end{tabular}

With respect to flavor (Table 5), the Uruguayan low-fat cheeses presented low values for all flavor attributes, indicating that this type of cheese is characterized by not being very tasty. For overall odor and taste intensity, the values barely varied among samples from 1.7 to 2.2 and from 1.7 to 2.6 , respectively. For both attributes the highest intensity was found in sample $\mathrm{A}$, while sample $\mathrm{C}$ corresponded to less intense taste. Sweetness and spiciness presented values lower than 1 and can be considered as attributes that are not characteristic of these cheese samples. Acidity of samples varied in a narrow range from 0.9 to 
1.5. The intensity of saltiness differed among samples, varying from 0.9 to 2.0. The salty taste was significantly more intense in samples A, D and F than in samples $\mathrm{B}, \mathrm{C}$ and $\mathrm{E}$. Although $\mathrm{NaCl}$ content in sample A (Table 2) was significantly lower than the rest of the samples, the intensity of salt perceived was similar to those samples with a higher $\mathrm{NaCl}$ content. This result suggests that the intensity of the perceived salty taste does not only depend on $\mathrm{NaCl}$ concentration. As stated in previous studies (Kilcast \& Rider, 2007; Ritvanen et al., 2010), differences in sample texture and the presence of other substances (fat, aroma and other taste compounds) may also be responsible for the variation in saltiness perceived. Regarding bitterness, sample C (1.8) significantly differed from the other samples for which the difference was not significant, with an average value of 0.94 . The aftertaste was in general low, varying from 1.0 to 1.8 . The most intense aftertaste corresponded to sample A.

In order to study the sensory differences among cheese samples, taking into account all sensory attributes, a principal component analysis (PCA) was performed. The first two principal components (PCs) were calculated and accounted for $88 \%$ of the variability in the cheese. The first principal component (PC1) explained $74 \%$ of the variance and was mainly related to texture attributes. It was positively correlated with firmness (tactile and in mouth) and negatively correlated with elasticity, impression of humidity, adhesiveness and also with bitterness. The second principal component (PC2) explained $14 \%$ of the variance and was mainly correlated with flavor attributes. According to its position on the map shown in Figure 2, the main characteristics that differed among samples can be identified. So, major differences among samples corresponded to differences in texture attributes. Sample B and C proved more elastic and less firm than the other samples. Also, sample $\mathrm{C}$ showed more impression of humidity and more bitterness than the others. Sample A was characterized by having a stronger aftertaste, odor intensity, taste intensity and saltiness, and an intermediate 
firmness. Samples D, E and F were less adhesive and firmer than the remaining samples.

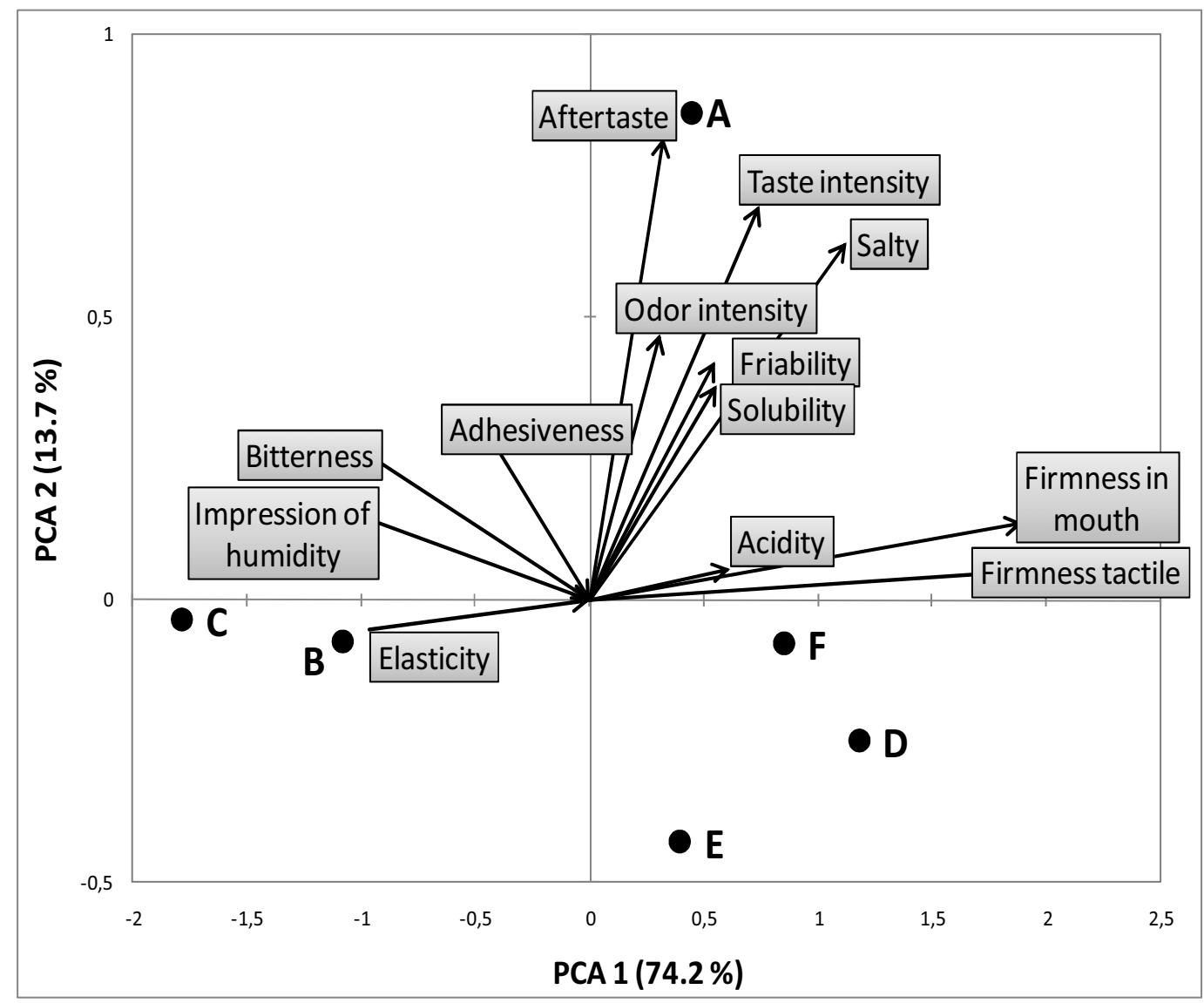

Figure 2. Principal component plot of cheese samples and sensory attributes. 


\section{Relationship between acceptance and sensory properties}

Acceptance of the low-fat cheeses was evaluated by eighty-four consumers. Analysis of variance showed that the acceptability significantly varied among samples $(\mathrm{F}=22.3, \mathrm{p}<0.0001)$. Consumers' liking scores differed greatly for the commercial Uruguayan low-fat cheeses. Sample A was the most liked (mean value of 6.8) while sample $\mathrm{C}$ was clearly disliked by consumers (mean value of 3.9). Samples B, D, E and F did not differ significantly from each other, with an intermediate liking score (mean values of 6.1, 5.9, 5.7 and 5.4, respectively).

In order to explain which differences in sensory properties were responsible for the differences in acceptance of the Uruguayan low-fat cheese samples, data were subjected to a Partial Least Square (PLS) regression. The model obtained explained $91.1 \%$ of the variability in cheese acceptability. In the PLS plot (Figure 3) the relationship between acceptance and sensory variables can be observed. Acceptance of this type of cheeses was mostly closely correlated with odor and taste intensity, aftertaste and bitterness, while others parameters like texture attributes and acid and salty taste were shown not to be correlated with acceptability. Sample A, with the most intense overall odor, overall taste and aftertaste, was the sample preferred the most. Conversely, sample $\mathrm{C}$ with the highest bitterness but very low odor and taste intensity was the least preferred sample. 


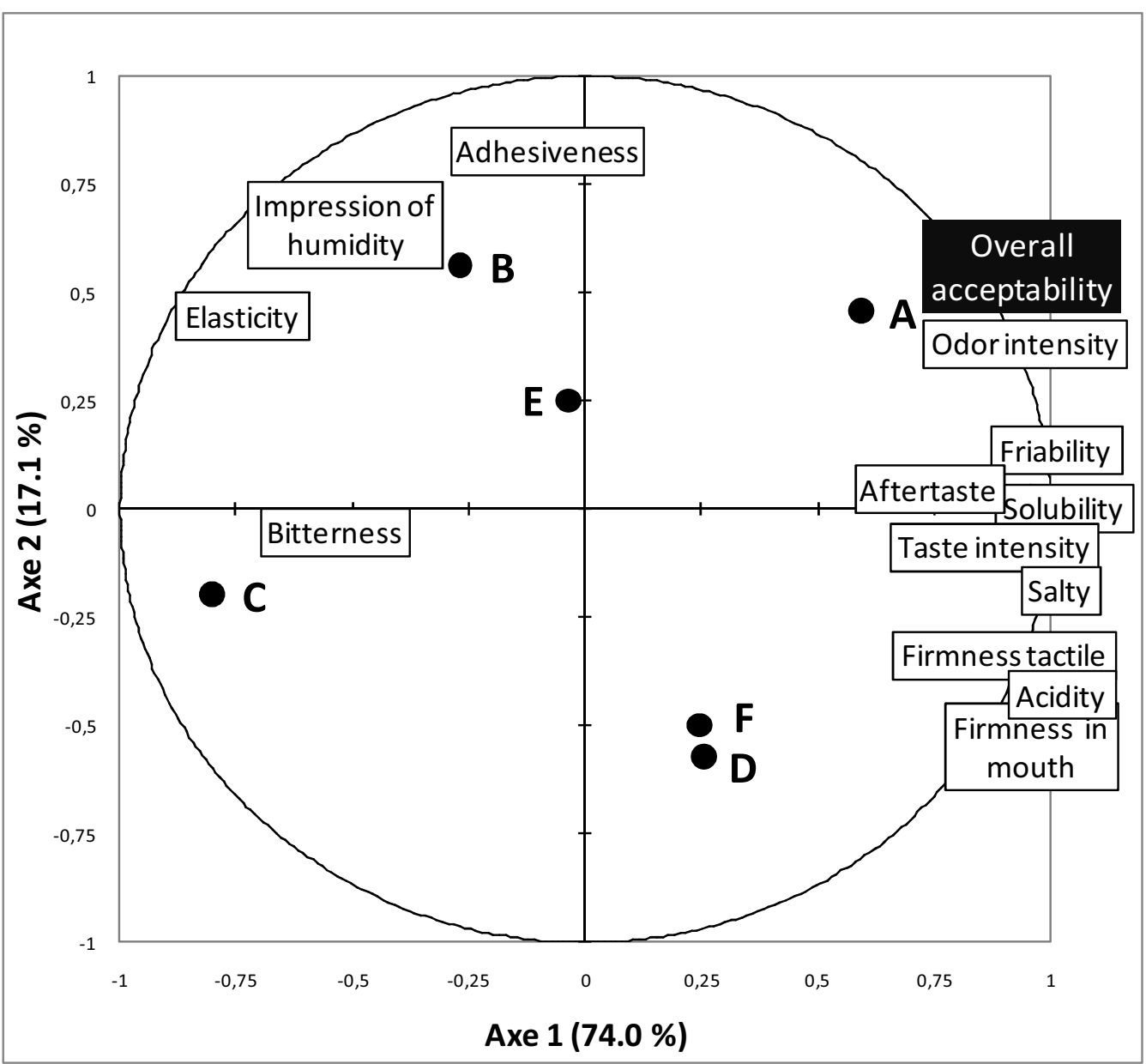

Figure 3. PLS regression analysis of cheese sensory attributes (X variables) and acceptability (Y variable).

\section{CONCLUSION}

In this work, the sensory properties of Uruguayan low-fat cheese "queso magro" have been described. According to the sensory profile of commercial samples, the cheeses are characterized by having a soft odor and taste, intermediate firmness, medium-high elasticity and little friability. The commercial low-fat cheeses mainly differed in their texture attributes, firmness and elasticity. 
However, flavor attributes were those that dictated the important differences in acceptance among the samples.

\section{ACKNOWLEDGMENTS}

The financial support of MICINN, Spain (Tarrega's contract within the Juan de la Cierva Programme) and financial support of LATU, Uruguay for Arcia's stay at IATA, are all gratefully acknowledged.

\section{REFERENCES}

Reglamento Bromatologico del Uruguay, (1994) Decreto No 315/994. 2nd ed.: 149-151. Dirección Nacional de Impresiones y Publicaciones Oficiales. Montevideo, Uruguay.

Brown, J. A., Foegeding, E. A., and Daubert, C. R. (2003) Relationships among rheological and sensorial properties of young cheeses. J. Dairy Sci. 86: 3054-3067.

Carbonell, L., Izquierdo, L., and Carbonell, I. (2007) Sensory analysis of Spanish mandarin juices. Selection of attributes and panel performance. Food Qual. and Pref. 18: 329-341.

Carlucci, A. and Monteleone, E. (2001) Statistical validation of sensory data: a study on wine. J. Sci. Food Agric. 81: 751-758.

Childs, J. L. and Drake, M. (2009) Consumer perception of fat reduction in cheese. J. Sens. Stud. 24: $902-921$.

Drake, M.A. and Swanson, B.G. (1995) Reduced- and low-fat cheese technology: A review. Trends Food Sci. Technol. 6: 366 - 369. 
Gallerani, G., Gasperi, F. and Monetti, A. (2000) Judge selection for hard and semi-hard cheese sensory evaluation. Food Qual. and Pref. 11, 465-474.

Gwartney, E. A., Foegeding, E. A. and Larick D. K. (2002) The texture of commercial full-fat and reduced-fat cheese. J. Food Sci. 67: 812-816.

Hernández-Morales, C.; Hernández-Montes, A.; Aguirre-Mandujano, E. and Villegas de Gante, A. (2010) Physicochemical, microbiological, textural and sensory characterisation of Mexican Añejo cheese. Int. J. Dairy Technol. 63 (4): 552- 560.

ISO, 2001. FIL 20-2:2001: Milk - Determination of nitrogen content - Block digestion method. Standard no: 8968-2. International Organization for Standardization, Genova, Switzerland.

ISO, 2004. FIL 4:2004: Cheese and processed cheese - Determination of the total solid content. Standard no: 5534. International Organization for Standardization, Genova, Switzerland.

ISO, 2006. FIL 88:2006: Cheese and processed cheese products - Determination of chloride content - Potentiometric titration method. Standard no: 5943. International Organization for Standardization, Genova, Switzerland.

ISO, 2007. Sensory analysis: General guidance for the design of test rooms. Standard no: 8589. International Organization for Standardization, Genova, Switzerland.

ISO, 2008. FIL 222:2008: Cheese - Determination of fat content - Van Gulik method. Standard no: 3433. International Organization for Standardization, Genova, Switzerland.

ISO, 2009. IDF 99-1: 2009: Milk and milk products. Sensory analysis. Part 1: General guidance for the recruitment, selection, training and monitoring of assessors. Standard no: 22935-1. International Organization for Standardization, Genova, Switzerland.

Jellinek, G. (1985) Sensory evaluation of food: theory and practice. West Sussex: Ellis Horwood Ltd. 
Kilcast, D., and Rider, C. (2007) Sensory issues in reducing salt in food products. In: T. P. Guinee, \& B. T. O'Kennedy (Eds.), Reducing salt in foods: Practical strategies CRC Press, Boca Raton, LA.

Lavanchy, P., Berodier, F., Zannoni, M., Noël, Y., Adamo, C., Squella, J. and Herrero, L. (1993) L' évaluation sensorielle de la texture des fromages á pate dure ou semidure. Étude interlaboratoires. Lebensm.-Wiss. Technol. 26: $5-68$.

MacFie, H. J., Bratchell, N., Greenhoff, K., and Vallis, L. V. (1989) Designs to balance the effect of order of presentation and first-order carry over effects in Hall Tests. J. Sens. Stud. 4: 129-148.

Meligaard, M., Civille, G. V., and Carr, B. T. (1999) Sensory evaluation techniques. 3rd ed. Boca Raton, Fla, USA: CRC Press.

Mistry, V. V. 2001. Low fat cheese technology. Int. Dairy J. 11: 413-422.

Montero, H., Aranibar, G., Cañameras, C., and Castañeda, R. (2005) Metodologías para la caracterización sensorial de quesos Argentinos. Jornadas de Análisis Sensorial (JASLIS 2005), 6 al 8 de septiembre. Buenos Aires

Ritvanen, T., Lilleberg, L., and Tupasela, T. (2010) The characterization of the most-liked reduced-fat Havarti-type cheeses. J. Dairy Sci. 93: 5039-5047.

Saint-Eve, A., Lauverjat, C., and Magnan, C. (2009) Reducing salt and fat content: Impact of composition, texture and cognitive interactions on the perception of flavoured model cheeses. Food Chem. 116: 167-175.

Stone, H. and Sidel, J. L. (1985) Sensory Evaluation Practices. Food Science and Technology, International Series. 3rd ed. Elsevier Academic Press, San Diego, United States.

Tarakci, Z., and Kucukoner, E. (2006) Note: Effect of Different Cultures on Physico-chemical and Sensory Properties of Low-fat Herby Cheese. Food Sci. Technol. Int. 12(5): 423-428. 
Ten Kleij, F., and Musters, P. A. D. (2003) Text analysis of open ended survey responses: a complementary method to preference mapping. Food Qual. and Pref. 14: 43-52.

United States Department of Agriculture. (1995) Nutrition and your health: dietary guidelines for Americans. Home Garden Bull. No. 232. US Govt. Printing Office. Washington, DC.

Woteki, C. E., and P. R. Thomas. (1993) in Eat for Life. Harper Collins Publ., Inc., New York, United States.

Yates, M. D., and Drake, M. A. (2007) Texture properties of gouda cheese. J. Sens. Stud. 22: $493-506$. 



\section{CAPÍTULO 3}

\section{Influence of expectations created by \\ label on consumers acceptance of Uruguayan low-fat cheeses}





\title{
INFLUENCE OF EXPECTATIONS CREATED BY LABEL ON CONSUMERS ACCEPTANCE OF URUGUAYAN LOW-FAT CHEESES
}

\author{
PATRICIA ARCIA ${ }^{1,2}$, ANA CURUTCHET ${ }^{2}$, ELVIRA COSTELL ${ }^{1}$, AMPARO \\ TÁRREGA ${ }^{1}$ \\ ${ }^{1}$ Physical and Sensory Properties Laboratory. Instituto de Agroquímica y Tecnología de Alimentos \\ (CSIC), Avda. Agustín Escardino, 7. 46980 Paterna (Valencia), Spain. \\ ${ }^{2}$ Laboratorio Tecnológico del Uruguay. Av. Italia 6201, C.P. 11500. Montevideo, Uruguay.
}

\begin{abstract}
This work focuses on how the expectation created by the label influences the consumer's acceptance and willingness to purchase low-fat Uruguayan cheeses. Six commercial low-fat cheeses were evaluated by a group of consumers who rated their expected liking by observing the label and the degree of liking on tasting the samples under blind and informed conditions. To identify the underlying relationships between product attributes and consumers' personal beliefs motivating their purchasing decision, laddering interviews were performed with another group of consumers. Results indicated that the label had a positive or neutral effect on consumers' hedonic perception. When hedonic expectations were not fulfilled, assimilation took place, either completely or incompletely, indicating that positive consumer expectations had a positive effect on acceptability ratings of these cheeses. For consumers, the two main components influencing the final decision on purchasing Uruguayan low-fat cheese were trust and expected pleasure. The brand, appearance and previous knowledge of the product were the characteristics on the label with most impact on consumers. In addition, certain brands and images on the label elicited
\end{abstract}


differentiating responses, like the sense of natural or traditional manufacture, which motivated some consumers to purchase the product

Key words: low-fat cheeses, label expectative, personal values, laddering.

\section{PRACTICAL APPLICATION}

To develop or improve products, it is necessary to provide the characteristics consumers seek in a product. Sensory properties are considered determining factors when choosing a product; however, they are not the only ones. The label is one of the extrinsic components of a product, playing an important role in consumer buying behavior, acting as a means to attract attention and provide information. This work shows how the expectative created by the label affected the acceptance of Uruguayan low-fat cheeses. To develop products with a higher likelihood of success, it is important to know which label characteristics are relevant to consumers and their underlying motivation.

\section{INTRODUCTION}

In Uruguay, "queso magro" is a variety of cheese with low fat content (10-25\%), for which there is increasing demand due to consumers' interest in low-calorie and healthy products. This work is part of a study aiming to investigate the factors that affect consumer acceptance of Uruguayan low-fat cheese. A previous study analyzed the influence of sensory characteristics on consumer acceptance of this type of Uruguayan low-fat cheese (unpublished results) and although sensory properties are considered determining factors in product choice, extrinsic product aspects also play an important role in this process (Guerrero et al., 2000). 
Product packaging is one of the extrinsic aspects that can affect consumer buying behavior, acting as a way to attract attention and provide information, thus affecting the perception of product quality (Chrea et al., 2011; Bower, et al., 2003). Furthermore, the opinion each consumer has about the nutritional characteristics or composition of the product (Vazquez et al., 2009; Siró et al., 2008), its safety (Wilcock et al., 2004) or brand (Torres et al., 2012) also conditions their choice at the time of purchasing. It is necessary to identify which extrinsic attributes (e.g., package or label information) are relevant to consumers in order to improve the likelihood of product acceptance (Carneiro et al. 2005). Expectations could be regarded as pre-trial beliefs about a product (Grunert, 2002), and hedonic expectations refer to how much the product will be liked / disliked before trying it. The consumer response will depend on whether or not the product meets their expectations (Costell et al., 2010). Claims, illustrations and symbols convey important information on what one can expect of the product by looking at the package. Previous studies have shown that package characteristics, and especially those related to the label, can influence consumer expectation and hedonic evaluation of food products (Mueller and Szolnoki, 2010; Deliza et al., 2003; Torres et al, 2012; Varela et al.,2010 Villegas et al, 2008). The label includes the brand, product information, design and aesthetics, and each of these factors can affect, either positively or negatively the overall image of the product and likewise product expectative, acceptability and consumer choice. To understand how the characteristics on the label influence consumer response laddering technique can be used. Laddering is a qualitative method that has previously been used to find self-relevant values that consumers associate to certain food types like functional, organic or high-quality foods (Bitzios et al., 2011; Baker and Guenther, 2004; Grunert et al., 2011). Laddering refers to an in-depth interview, used to develop an understanding of the structure of the concepts that are relevant for the respondent. It is based on the means-end chain theory, which is a model of the consumers' cognitive structures focused on 
how product attributes (the "means") are linked to self-relevant consequences and personal values (the "ends") (Sorensen and Askegaard, 2007). There are two main laddering alternatives, soft and hard laddering. Hard laddering relies upon a structured questionnaire, while soft-laddering is based on a personal interview performed by an interviewer.

The aim of this work was to investigate how Uruguayan consumers' expectations generated by the label influenced their acceptance of commercial low-fat cheeses. The study also sought to establish the personal values that consumers associate to label characteristics.

\section{MATERIALS AND METHODS}

\section{Samples}

Six Uruguayan commercial low-fat cheeses were evaluated. The selection criteria were based on a previous analysis of the commercial product range and on their availability in almost all big supermarkets in Montevideo. The samples were purchased from the market (coded from 1 to 6), taking into account expiry dates and were stored under refrigeration $\left(4 \pm 1^{\circ} \mathrm{C}\right)$ until testing. Samples were evaluated at the same timeframe from production, approximately two months. The characteristics of the label of each sample are described in Table 1. 
Table 1. Label characteristics for the six commercial Uruguayan low fat cheeses.

\begin{tabular}{|c|c|c|c|}
\hline Sample & Label appearance & $\begin{array}{c}\text { Product } \\
\text { description }\end{array}$ & Nutritional information content \\
\hline 1 & $\begin{array}{l}\text { Label in black on } \\
\text { white. } \\
\text { No image. }\end{array}$ & Low-fat cheese & $\begin{array}{l}\text { For portion }(30 \mathrm{~g}) \text { : Energy }=58 \mathrm{kcal} \text {, Carbohydrates } \\
=0.8 \mathrm{~g} \text {, Proteins }=8.1 \mathrm{~g} \text {, Total fat }=3.0 \mathrm{~g} \text {, Saturated } \\
\mathrm{fat}=1.8 \mathrm{~g} \text {, Trans fat }=0.1 \mathrm{~g} \text {, Fiber }=0 \mathrm{~g} \text {, Sodium }= \\
120 \mathrm{mg}\end{array}$ \\
\hline 2 & $\begin{array}{l}\text { Full colored label. } \\
\text { No image. }\end{array}$ & $\begin{array}{l}\text { Low fat cheese } \\
\text { with salt }\end{array}$ & $\begin{array}{l}\text { For portion }(30 \mathrm{~g}): \text { Energy }=73.2 \mathrm{kcal} \text {, } \\
\text { Carbohydrates }=0.8 \mathrm{~g} \text {, Proteins }=8.0 \mathrm{~g} \text {, Total fat }= \\
4.2 \mathrm{~g} \text {, Saturated fat }=2.7 \mathrm{~g}, \quad \text { Trans fat }=0 \mathrm{~g} \text {, Fiber } \\
=0 \mathrm{~g} \text {, Sodium }=102 \mathrm{mg}\end{array}$ \\
\hline 3 & $\begin{array}{l}\text { Full colored label. } \\
\text { Image of diced } \\
\text { cheese. }\end{array}$ & Low fat & $\begin{array}{l}\text { For portion }(50 \mathrm{~g}): \text { Energy }=101 \mathrm{kcal} \text {, Carbohydrates } \\
=0 \mathrm{~g}, \text { Proteins }=14 \mathrm{~g} \text {, Total fat }=5.0 \mathrm{~g} \text {, Saturated fat } \\
=3.0 \mathrm{~g} \text {, Trans fat }=0 \mathrm{~g}, \text { Sodium }=167 \mathrm{mg} \text {, Calcium } \\
=490 \mathrm{mg}\end{array}$ \\
\hline 4 & $\begin{array}{l}\text { Full colored label. } \\
\text { No image. }\end{array}$ & $\begin{array}{l}\text { Low fat cheese } \\
\text { with salt }\end{array}$ & $\begin{array}{l}\text { For portion }(30 \mathrm{~g}) \text { : Energy }=72 \mathrm{kcal} \text {, Carbohydrates }= \\
0.6 \mathrm{~g} \text {, Proteins }=9.9 \mathrm{~g} \text {, Total fat }=3.3 \mathrm{~g} \text {, Saturated } \\
\text { fat }=2.1 \mathrm{~g}, \quad \text { Trans fat }=0 \mathrm{~g} \text {, Fiber }=0 \mathrm{~g} \text {, Calcium } \\
=293 \mathrm{mg} \text {, Sodium }=180 \mathrm{mg}\end{array}$ \\
\hline 5 & $\begin{array}{l}\text { Full colored label. } \\
\text { Image of } \\
\text { countryside. }\end{array}$ & Low fat & NO nutritional information \\
\hline 6 & $\begin{array}{l}\text { Full colored label. } \\
\text { Image of diced } \\
\text { cheese. }\end{array}$ & $\begin{array}{l}\text { Low fat cheese } \\
\text { with salt }\end{array}$ & $\begin{array}{l}\text { For portion }(30 \mathrm{~g}) \text { : Energy }=80 \mathrm{kcal} \text {, Carbohydrates } \\
=0.6 \mathrm{~g} \text {, Proteins }=9.0 \mathrm{~g} \text {, Total fat }=4.6 \mathrm{~g} \text {, Saturated } \\
\mathrm{fat}=2.6 \mathrm{~g} \text {, Trans fat }=0.3 \mathrm{~g} \text { Fiber }=0 \mathrm{~g} \text {, Sodium }= \\
129 \mathrm{mg}\end{array}$ \\
\hline
\end{tabular}

\section{Consumer acceptability}

Evaluations were carried out in a standardized test room (ISO 8589, 2007). Eighty-four Uruguayan consumers participated in this study (45 women and the 39 men, from 18 to 66 years old). Of these, 17\% consume low-fat cheese every day, $36 \%$ consume it more than one day per week while the rest of them consume low-fat cheese less than once a week. Cheeses samples were cut into sticks measuring approximately $1.5 \times 1.5 \mathrm{~cm}$ and $5 \mathrm{~cm}$ in height, served at room temperature $\left(20^{\circ} \mathrm{C}\right)$ in transparent plastic dishes, coded with three-digit random numbers. Mineral water and crackers were provided for mouth-rinsing. Cheese labels were coded with three-digit random numbers too. The presentation order of samples and labels was equilibrated among consumers following a Williams design (MacFie et al., 1989). Evaluations were done in three different conditions 
in two different sessions. The first session was divided in two parts. First, consumers were asked to taste and evaluate the acceptability of cheese samples without information (blind condition). Consumers evaluated the overall acceptability of the six samples of low-fat cheese using a hedonic nine-point scale ranging from "I dislike extremely" ("Me disgusta muchísimo") to "I like extremely" ("Me gusta muchísimo"). Once consumers finished the blind evaluation, they were provided with the label of each cheese sample and were asked to rate how much they considered that they would like the product (expected condition).

The second session took place one month later (only seventy-three consumers completed the trial) when consumers were provided with the cheese sample and its corresponding label. In this case they were asked to taste the sample and rate its acceptability, taking into account the label (informed condition).

\section{Soft laddering}

In parallel, another group of 41 consumers participated in this evaluation. Each consumer was interviewed in an individual session of 30-45 minutes. The six cheese labels were simultaneously presented to each participant. The interviewer asked the participant "If you were at the supermarket buying cheese, which of these cheeses would you choose? And from the remaining samples, which would you choose? And then?" Thus the interviewer continued asking until the rank order of choice was completed for all six cheese samples. After that, each label was presented individually to the consumer, who was asked if he/she would buy, or not, the corresponding cheese. Finally, the reasons for buying or not buying the product were established using a series of "why" questions (Sørensen and Askegaard, 2007). 


\section{Data analysis}

One way analysis of variance (ANOVA) was performed on the acceptability data obtained under blind, expected and informed conditions. Significant differences among samples were determined by the Fisher test $(\alpha \leq 0.05)$.

Differences between acceptability values for the "expected" and "blind" (E-B) conditions, between "informed" and "blind" (I-B) conditions and between "informed" and "expected" (I-E) conditions, were calculated and their significance was determined by the t-Student test $(\alpha \leq 0.05)$.

Friedman Analysis of Variance was applied to data of the ranking test and significance of differences between samples were determined by the Fisher test $(\alpha=0.05)$, as modified for non-parametric data (Meilgaard et al., 1999). Data from the laddering task was analyzed as proposed by Reynolds and Gutman (1988). Attributes, consequences and values having the same meaning were grouped together and coded. With this information, diagrams showing relationships among attributes, consequences and values (Hierarchical value maps: HVM) were constructed. The cut-off points used in the hierarchical value maps were chosen as $10 \%$ of the size of the consumer sample (Reynolds \& Gutman, 1988).

Analyses were performed using XLSTAT Version 2011 (Addinsoft 1995-2010, France). 


\section{RESULTS}

\section{Expectations created by label and their effects on acceptability}

When consumers evaluated the product under the blind condition, acceptance scores varied greatly among the commercial cheese samples $(F=23.8, p<$ 0.0001). Liking scores ranged from 3.9 to 6.8 (Table 2). Consumers clearly disliked sample 3 while samples 6 and 1 were the most liked. Results of the expected liking also varied significantly among samples $(\mathrm{F}=47.6, \mathrm{p}<0.0001)$. Consumers rated two samples (6 and 3 ) with a high expected liking score $(\geq 7)$ and rated one of the samples (1) with a low score (Table 2).

Table 2. Mean liking scores of acceptability and standard deviation for the six evaluated samples for the three evaluations conditions considered.

\begin{tabular}{|c|c|c|c|}
\hline \multirow[t]{2}{*}{ Sample } & \multicolumn{3}{|c|}{ Acceptability } \\
\hline & Expected (E) & Blind (B) & Informed (I) \\
\hline 1 & $\begin{array}{l}3.9^{\mathrm{e}} \\
(2.0)\end{array}$ & $\begin{array}{l}6.2^{\mathrm{ab}} \\
(1.5)\end{array}$ & $\begin{array}{c}6.7^{\mathrm{a}, \mathrm{b}} \\
(1.7)\end{array}$ \\
\hline 2 & $\begin{array}{l}6.4^{c} \\
(1.3)\end{array}$ & $\begin{array}{l}5.4^{\mathrm{c}} \\
(1.9)\end{array}$ & $\begin{array}{l}6.3^{b} \\
(1.9)\end{array}$ \\
\hline 3 & $\begin{array}{l}7.0^{\mathrm{a}, \mathrm{b}} \\
(1.4)\end{array}$ & $\begin{array}{l}3.9^{\mathrm{d}} \\
(2.0)\end{array}$ & $\begin{array}{l}5.5^{c} \\
(2.0)\end{array}$ \\
\hline 4 & $\begin{array}{l}5.9^{\mathrm{d}} \\
(1.9)\end{array}$ & $\begin{array}{c}5.9^{\mathrm{b}, \mathrm{c}} \\
(1.7)\end{array}$ & $\begin{array}{l}6.4^{b} \\
(1.9)\end{array}$ \\
\hline 5 & $\begin{array}{c}6.6^{\mathrm{b}, \mathrm{c}} \\
(1.6)\end{array}$ & $\begin{array}{c}5.7^{\mathrm{b}, \mathrm{c}} \\
(1.9)\end{array}$ & $\begin{array}{c}6.8^{\mathrm{a}, \mathrm{b}} \\
(1.8)\end{array}$ \\
\hline 6 & $\begin{array}{l}7.2^{\mathrm{a}} \\
(1.5)\end{array}$ & $\begin{array}{l}6.8^{\mathrm{a}} \\
(2.0)\end{array}$ & $\begin{array}{l}7.0^{\mathrm{a}} \\
(1.6)\end{array}$ \\
\hline
\end{tabular}


These important differences among sample scores indicated that differences in the label (brand, information or appearance) clearly generated different consumer expectations.

On observing label characteristics (Table 1), it seems that differences in appearance could explain the observed differences in expected liking. Unlike the other samples, samples 3 and 6 showed images of cheese on their labels that could result attractive to consumers, while the label on sample 1 was the only one printed in black on white and lacked an image. Under the informed condition, the liking scores of samples also varied significantly $(F=5.8, p<0.001)$ although in this case they varied in a narrower range (5.5 to 7.0) than in the expected and blind conditions (Table 2). Therefore, differences among samples were less pronounced when consumers were aware about what they tasted than for the blind and expected conditions. To study the effect of expectations on the acceptability of these commercial low-fat cheeses, mean scores for each sample were compared in the blind condition (B), in the expected condition (E) and in the informed condition (I). A significant E-B difference revealed that a disconfirmation occurred. When informed minus blind scores (I-B) were significant, this revealed the label affected the informed liking scores. An assimilation effect was revealed when $(\mathrm{I}-\mathrm{B}) /(\mathrm{E}-\mathrm{B})>0$ and this indicated that liking after exposure to label was influenced in the direction of expected liking. When assimilation was detected, informed minus expected scores (I-E) were calculated. Significant differences meant that assimilation was not complete and both the sensory hedonic dimension and label expectation had an impact on the informed scores.

In the present study, results show different situations for different samples (Table 3 ). For samples 4 and 6 , the difference between consumer expected liking and blind liking was not significant. That means that these products met consumer expectations. The expectative of sample 6 was the highest and it was fulfilled by the product while in the case of sample 1 the difference between E-B was 
negative (positive disconfirmation). On observing the label, consumers expected to dislike the product, but when they tasted the cheese sample they liked it. In this case I-B was not significant indicating that the negative expectation caused by the label did not affected actual acceptability of the sample. Furthermore, the informed score was determined by the sensory hedonic dimension. For samples 2 and 5, the difference E-B was significant and positive, which means that the expected liking according to label was higher than the actual liking when tasting the product (negative disconfirmation). For these samples, the difference I-B was also significant and $(\mathrm{I}-\mathrm{B}) /(\mathrm{E}-\mathrm{B})>0$ indicating that the discrepancy between expected and actual liking of the product was assimilated by the consumer and the informed liking moved in the direction of the expected liking. Furthermore there was not a significant difference between I-E, indicating that the assimilation was complete. Sample 3 presented the largest difference between blind and expected liking scores (negative disconfirmation). The label created high hedonic expectations in consumers who disliked the sample on tasting it in the blind condition. The difference between I-B was also significant and positive, indicating that assimilation occurred. However, in this case the difference between the informed condition and the expected condition (I-E) was significant, indicating that assimilation was not complete and the liking of cheese when the label was available fell between the blind score and the expected score.

These results reveal the impact the label has on consumer acceptability of Uruguayan low-fat cheese. When consumers were only provided a label to react to, expected liking for the cheese varied widely, indicating that the characteristics on the label only had a positive or neutral effect on consumers' hedonic perception. When hedonic expectations were not fulfilled, assimilation took place, either completely or incompletely. Thus, positive consumer expectations had a positive effect on rated acceptability of this type of cheese, as previously observed for other food products (Cardello et al. 1985; Allison and Uhl, 1964; Monaco et al., 2004; Varela et al., 2010; Villegas et al., 2008). 
Table 3. Means values (M) and significance ( $p$, probability according t- test) of differences between acceptability values of samples obtained under different conditions. Blind $=\mathrm{B}$, Expected $=\mathrm{E}$ and Informed $=\mathrm{I}$.

\begin{tabular}{|c|c|c|c|c|c|c|}
\hline \multirow{2}{*}{ Sample } & \multicolumn{2}{|c|}{ E - B } & \multicolumn{2}{|c|}{$\mathrm{I}-\mathrm{B}$} & \multicolumn{2}{|c|}{$\mathrm{I}-\mathrm{E}$} \\
\hline & $\mathrm{M}$ & $p$ & $\mathrm{M}$ & $p$ & $\mathrm{M}$ & $P$ \\
\hline \multirow[t]{2}{*}{1} & -2.3 & $<0.001$ & 0.5 & 0.073 & & \\
\hline & \multicolumn{2}{|c|}{ Disconfirmation $(+)$} & \multicolumn{2}{|c|}{ N.S. } & & \\
\hline \multirow[t]{2}{*}{2} & 1.0 & $<0.001$ & 1.5 & 0.020 & 0.4 & 0.490 \\
\hline & \multicolumn{2}{|c|}{ Disconfirmation (-) } & \multicolumn{2}{|c|}{ Assimilation } & \multicolumn{2}{|c|}{ Complete assimilation } \\
\hline \multirow[t]{2}{*}{3} & 3.1 & $<0.001$ & 1.6 & $<0.001$ & -1.5 & $<0.001$ \\
\hline & \multicolumn{2}{|c|}{ Disconfirmation (-) } & \multicolumn{2}{|c|}{ Assimilation } & & \\
\hline \multirow[t]{2}{*}{4} & 0.0 & 0.930 & 0.5 & 0.080 & & \\
\hline & \multicolumn{2}{|c|}{ N.S. } & \multicolumn{2}{|c|}{ N.S. } & & \\
\hline \multirow[t]{2}{*}{5} & 1.0 & $<0.001$ & 1.1 & 0.000 & 0.1 & 0.630 \\
\hline & \multicolumn{2}{|c|}{ Disconfirmation (-) } & \multicolumn{2}{|c|}{ Assimilation } & \multirow{2}{*}{\multicolumn{2}{|c|}{ Complete assimilation }} \\
\hline 6 & 0.4 & 0.140 & 0.2 & 0.470 & & \\
\hline & \multicolumn{2}{|c|}{ N.S. } & \multicolumn{2}{|c|}{ N.S. } & & \\
\hline
\end{tabular}

\section{Label characteristics affecting willingness to purchase}

The expected scores varied widely among cheese samples, indicating that some of the characteristics on the label had an impact on consumer response. It may be supposed that these elements can affect each consumer differently depending on his/her personal motivations and values. In this second part of the study, a laddering technique was used to provide information about consumers' motivations for purchasing or rejecting the cheese product on the basis of its label. Results of rankings tests of participants also showed that the order of choice varied among labels (Table 4). Sample 6 occupied the two first positions 
of choice more frequently than the rest of samples while sample 1 occupied more frequently the two last positions. For all cheese samples, the percentage of consumers that indicated they would buy the cheese was high ( $\geq 59 \%$ ), although variations were observed among samples (Table 4).

Table 4 Order of choice and buying intention of cheese samples according to its label indicated by consumers $(n=41)$ during laddering interviews.

\begin{tabular}{cccc}
\hline Sample & $\begin{array}{c}\text { N. of times label was } \\
\text { chosen at } 1^{\text {st }} \text { or } 2^{\text {nd }} \text { position }\end{array}$ & $\begin{array}{c}\text { N. of times label was } \\
\text { chosen at } 5^{\text {th }} \text { or } 6^{\text {th }} \text { position }\end{array}$ & $\begin{array}{c}\text { N. of participants that } \\
\text { would buy the cheese }\end{array}$ \\
\hline 1 & 10 & 23 & 28 \\
2 & 2 & 18 & 24 \\
3 & 21 & 9 & 29 \\
4 & 7 & 20 & 27 \\
5 & 15 & 11 & 34 \\
6 & 27 & 1 & 41 \\
\hline
\end{tabular}

Consumers' responses indicating their reasons for buying or not buying each sample were analyzed and summarized independently by two researchers, according to the levels of abstraction (Attribute - Consequence - Value) of the MEC theory. Overall, 9 attribute codes, 12 consequence codes and 7 value codes were elicited from the whole set of responses, considering both the reason for buying and not buying the samples (Table 5 and 6 respectively). A total of 18 ladders were obtained. Then dominant connections were graphically represented in a tree diagram, termed a Hierarchical Value Map (HVM). The cut-off points were set on 4 relations (10\% of the size of the consumer sample). The general HMV map with the constructs for buying and rejecting the samples are shown in Figures 1 and 2, respectively. Individual HVM maps were also obtained for each sample, although they are not shown to avoid repetition of Table 5. 
Table 5. Consumers' motives to purchase the cheese samples according to their labels.

\begin{tabular}{|c|c|c|c|c|c|c|c|c|c|}
\hline \multirow[t]{2}{*}{ Attributte } & \multirow[t]{2}{*}{ Consequence } & \multirow[t]{2}{*}{ Value } & \multirow{2}{*}{$\begin{array}{c}\text { Frequency of } \\
\text { occurrence } \\
(\%)\end{array}$} & \multicolumn{6}{|c|}{$\begin{array}{c}\text { Frequency of occurrence for } \\
\text { each sample }\end{array}$} \\
\hline & & & & 1 & 2 & 3 & 4 & 5 & 6 \\
\hline Brand Known & Good quality & Trust & 22.7 & 12 & 7 & 22 & 0 & 0 & 23 \\
\hline Brand Known & --- & Trust & 13.1 & 7 & 14 & 0 & 8 & 8 & 0 \\
\hline Information is clear & Good quality & Trust & 1.8 & 0 & 2 & 1 & 0 & 0 & 2 \\
\hline Brand Known & Good taste & Pleasure & 9.9 & 6 & 1 & 6 & 10 & 11 & 0 \\
\hline Product known & Good taste & pleasure & 11.0 & 4 & 2 & 0 & 0 & 0 & 19 \\
\hline Label appeareance & Good taste & Pleasure & 7.4 & 0 & 0 & 3 & 0 & 4 & 14 \\
\hline Label appeareance & $\begin{array}{l}\text { Image of cheese / Good } \\
\text { taste }\end{array}$ & Pleasure & 2.5 & 0 & 0 & 5 & 0 & 0 & 2 \\
\hline Brand & $\begin{array}{l}\text { Traditional manufacture } \\
\text { Good taste }\end{array}$ & Pleasure & 0.4 & 0 & 0 & 0 & 1 & 0 & 0 \\
\hline Brand & Traditional manufacture & $\begin{array}{l}\text { Social } \\
\text { impact }\end{array}$ & 4.3 & 0 & 0 & 0 & 3 & 4 & 5 \\
\hline Label appearance & $\begin{array}{l}\text { Image of country/ } \\
\text { Nature/ natural product }\end{array}$ & $\begin{array}{l}\text { Quality of } \\
\text { life }\end{array}$ & 3.2 & 0 & 0 & 0 & 0 & 9 & 0 \\
\hline Low fat content & Weight control & $\begin{array}{l}\text { Good } \\
\text { Looking }\end{array}$ & 0.4 & 0 & 0 & 1 & 0 & 0 & 0 \\
\hline
\end{tabular}

Table 6. Consumers' motives to reject purchasing cheese samples according to they labels.

\begin{tabular}{|c|c|c|c|c|c|c|c|c|c|}
\hline \multirow[t]{2}{*}{ Attributte } & \multirow[t]{2}{*}{ Consequence } & \multirow[t]{2}{*}{ Value } & \multirow{2}{*}{$\begin{array}{c}\text { Frequency of } \\
\text { occurrence } \\
(\%)\end{array}$} & \multicolumn{6}{|c|}{$\begin{array}{c}\text { Frequency of occurrence for } \\
\text { each sample }\end{array}$} \\
\hline & & & & 1 & 2 & 3 & 4 & 5 & 6 \\
\hline Product known & Bad taste & Not pleasure & 7.1 & 0 & 5 & 12 & 3 & 0 & 0 \\
\hline Product unknown & I should try & & 6.0 & 1 & 4 & 0 & 6 & 6 & 0 \\
\hline Label ugly & Bad taste & Not pleasure & 6.0 & 9 & 5 & 0 & 3 & 0 & 0 \\
\hline Information not clear & & Distrust & 2.1 & 0 & 2 & 0 & 4 & 0 & 0 \\
\hline Brand name & Low quality & Distrust & 1.4 & 0 & 0 & 0 & 4 & 0 & 0 \\
\hline Product unknown & Bad quality & Distrust & 0.4 & 1 & 0 & 0 & 0 & 0 & 0 \\
\hline Brand & The price is high & & 0.4 & 0 & 0 & 0 & 0 & 1 & 0 \\
\hline
\end{tabular}


It was observed that the basic cognitive areas of trust and pleasure appeared in every HVM, but they were constructed in a different way depending on the attributes that consumers found on each label. Trust is a feeling about satisfaction because of its ability to moderate risk in the buying process (Anderson and Narus, 1990). Brand was the attribute leading to consumer trust. For an important proportion of consumers, a known brand meant a good quality product and created trust. In all cases, trust in brand appeared as a reason to buy the sample, and for most samples (except 4 and 5) it was the most frequently mentioned reason (Table 5). For some consumers, the fact that the information shown on the label was clearly presented also gave the sensation of trust. This occurred for samples 2, 3 and 6, but at a very low frequency.

Pleasure also motivated a proportion of consumers to purchase cheese samples. The brand or previous knowledge of the product led consumers to think that the product would taste good. For some of consumers, the attractive image on the label (samples 3, 5 and 6) caused the sensation that the product would taste good and be pleasurable. More concisely, some consumers indicated that the product image on the label (a piece of cheese or diced cheese) made them think the product would taste good.

For samples 4, 5 and 6 the brands conveyed an image of traditional manufacture, which made some consumers consider the social impact/implications The image of the countryside on the label of sample 5 led to some consumers to think it was a natural product and to confer it the value of "quality of life". It should be noted that only one consumer paid attention to nutritional information and declared that he would buy the sample because it had the lowest fat content. However, for most consumers, nutritional information was not relevant to their purchase decision, probably because they considered low-fat cheese to be a healthy product by itself and thus they did not need any extra information to convince them of this fact. Similarly, some authors found that information about nutritional composition did not affect consumer buying decisions nor 
acceptability in the case of products with a "healthy image" like yogurts (Kähkönen \& Tuorila, 1999; Bayarri et al. 2010).

The reasons for not buying the cheese were the feelings of distrust and lack of pleasure. The non attractive label and the previous negative experience of a known product were the reasons why consumers thought the product would not taste good and that it would be unpleasant. The "name" of the product, the lack of clear information or the lack of previous knowledge made consumers distrust the product.

For consumers, the two main components in the final purchasing decision of the Uruguayan low-fat cheese were trust and pleasure. Therefore market positioning should pay attention to these personal consumer priorities, which are conveyed through certain characteristics on the label, mainly the brand, the appearance and previous knowledge of the product. In addition, brand and appearance of the label can elicit certain differentiating features, like the sense of natural or traditional manufacture that can also motivate a proportion of consumers to purchase the product. 


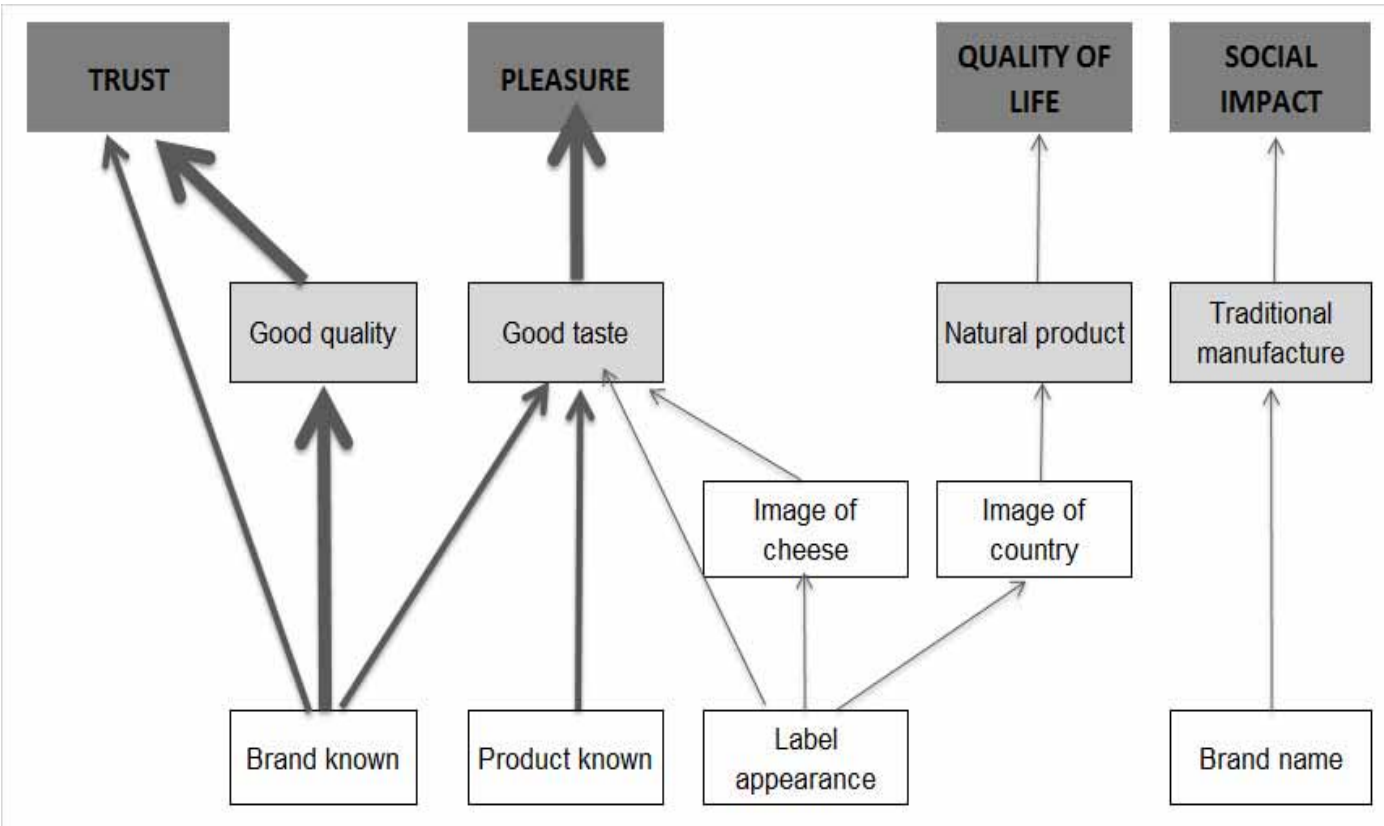

Figure 1. Laddering plot of consumer motivations for buying Uruguayan low fat cheese according to the label characteristics. 


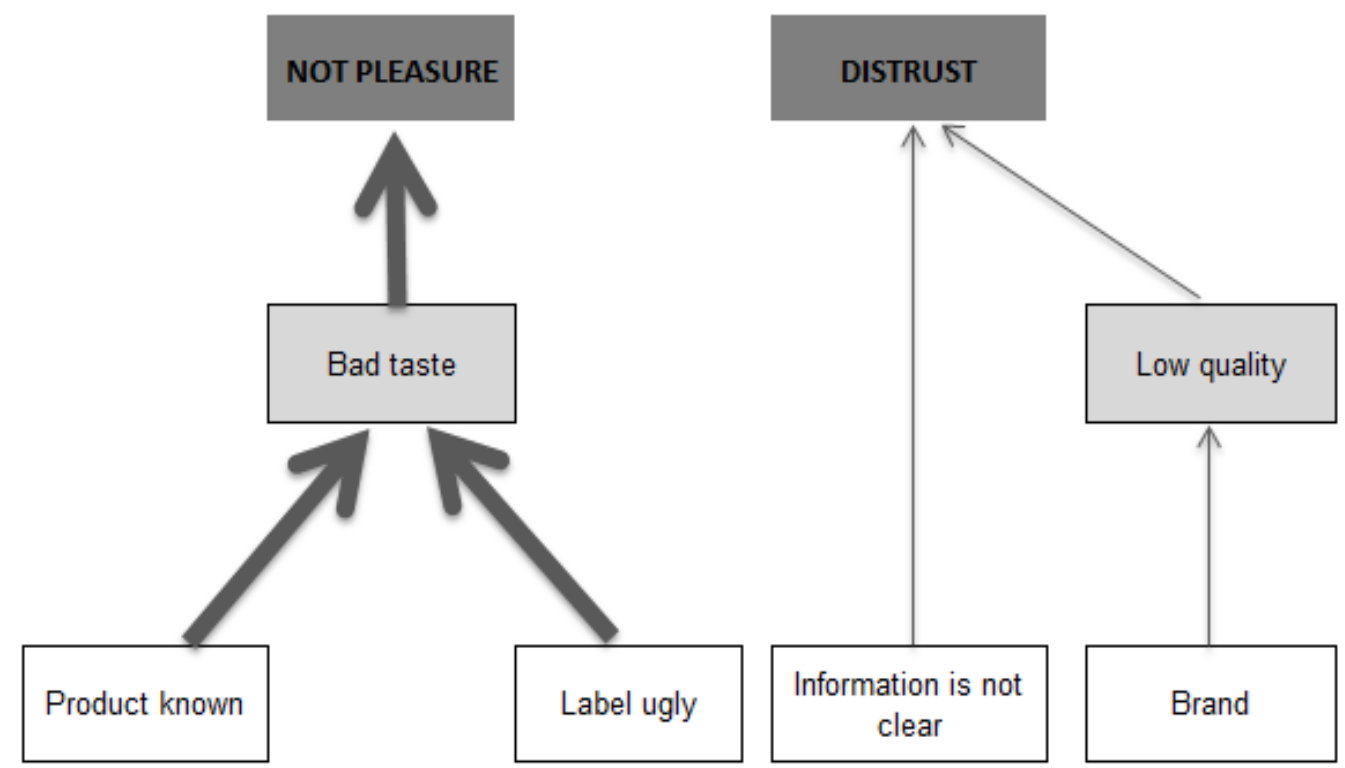

Figure 2. Laddering plot of consumer motivations for not buying Uruguayan low fat cheese according to the label characteristics.

\section{CONCLUSION}

Consumer expectations created by the label differed widely among the commercial Uruguayan low-fat cheeses evaluated. The influence of these expectations on final acceptability of product depended not only on the label but also on the sensory characteristics of the cheese. In general, positive consumer expectations created by label had a positive or neutral effect on acceptance of the cheese sample. Negative expectations did not affect the final acceptance of cheese because taste outweighed the negative impact of label. Trust and pleasure were the two main values motivating a consumer to purchase a Uruguayan lowfat cheese product. The attributes leading to consumers trust were mainly brand, 
appearance and previous knowledge of the product. In addition, label design can lead people to think that the product will taste good or bad and thus imagine the pleasure they could experience from it. In this case, an image of the product on the label (pieces of cheese) was the main feature that made the label attractive to consumers.

\section{ACKNOWLEDGMENTS}

The financial support of MICINN, Spain (Tarrega's contract within the Juan de la Cierva Programme) and financial support of LATU, Uruguay for Arcia's stay at IATA, are all gratefully acknowledged.

\section{REFFERENCES}

AFZAL, H., KHAN, M. A., REHMAN, K., ALI I., and WAJAHAT, S. 2010. Consumer's Trust in the Brand: Can it Be Built through Brand Reputation, Brand Competence and Brand Predictability. Int. Business Research, 3, 43-50

BAKER, R. and GUENTHER, C. 2004. The role of carotenoids in consumer choice and the likely benefits from their inclusion into products for human consumption. Trends in Food Sci. Technol. 15, 484-488

BAYARRI, S., CARBONELL, I., BARRIOS, E. and COSTELL, E. 2010. Acceptability of yogurt-like products: influence of product information and consumer characteristics and preferences. J. Sens. Stud. 25, 171-189

BITZIOS, M., FRASER, I., and HADDOCK-FRASER, J. 2011. Functional ingredients and food choice: Results from a dual-mode study employing 
means-end-chain analysis and a choice experiment. Food Policy, 36, 714724.

BOWER, J. A., SAADAT, M. A. and WHITTEN, C. 2003. Effect of liking, information and consumer characteristics on purchase intention and willingness to pay for a fat spread with a proven health benefit. Food Qual. and Prefer. 14, 65-74.

CARNEIRO, J., MINIM, V., DELIZA, R., SIlvA, C., CARNEIRO, J., and LEÃO, F. 2005. Labelling effects on consumer intention to purchase for soybean oil. Food Qual. and Prefer. 16, 275-282

CHREA, C., MElO, L., EVANS, G., FORDE, C., DELAHUNTY, C., and COX, D.N. 2011. An investigation using three approaches to understand the influence of extrinsic product cues on consumer behavior: An example of Australian wines. J. Sens. Stud. 26, 13-24.

COSTELL, E., TÁRreGA, A. and BAYARRI, S. 2010. Food Acceptance: The Role of Consumer Perception and Attitudes. Chem. Percept. 3, 42-50

DELIZA, R., MACFIE, A., and HEDDERLEY, A. 2003. Consumer attitude towards information on non conventional technology. Trends in Food Sci. Technol. 14, 43-49

GRUNERT, K. G. 2002. Current issues in the understanding of consumer food choice. Trends in Food Sci. Technol., 13, 275-285

GRUNERT, K. G., LAHTEENMAKI, L., and NIELSEN, N. A. 2011. Consumer perceptions of food products involving genetic modification - results from a qualitative study in four Nordic countries. Food Qual. and Pref. 12, 527542.

GUERRERO, L., COLOMER, Y., GUARDIA, M., XICOLA, J., and CLOTET, R. 2000. Consumer attitude towards store brands. Food Qual. and Prefer. 11, 387-95. 
ISO, 2007. Sensory analysis: General guidance for the design of test rooms. Standard no: 8589. International Organization for Standardization, Genova, Switzerland.

KÄHKÖNEN, P. and TUORILA, H. 1999. Consumer responses to reduced and regular fat content in different products: effects of gender, involvement and health concern, Food Qual. and Pref. 10, 83-91.

MACFIE, H., BRATCHELL, N., GREENHOFF, K., and VALLIS, L. 1989. Designs to balance the effect of order of presentation and first-order carry over effects in Hall Tests. J. Sens. Stud. 4, 129-148.

MEILGAARD, M., CIVILLE, G. V., and CARR, B. T. 1999. Sensory evaluation techniques. 3rd ed. Boca Raton, FL.

MONACO R. DI, CAVELLA S., and MARZO S. DI. 2004. The effect of expectations generated by brand name on the acceptability of dried semolina pasta. Food Qual. and Pref. 15, 429-437

MUELLER, S. and SZOLNOKI, G. 2010. The relative influence of packaging, labelling, branding and sensory attributes on liking and purchase intent: Consumers differ in their responsiveness. Food Qual. and Pref. 21, 774783.

REYNOLDS, T. and GUTMAN, J. 1988. Laddering theory, method, analysis, and interpretation. J. Advertising Research, 28 (1), 11-31.

SIRÓ, I., KÁPOLNA, E., KÁPOLNA, B. and LUGASI, A. 2008. Functional food. Product development, marketing and consumer acceptance - A review. Appetite, 51, 456-467.

SØRENSEN, E. B. and ASKEGAARD, S. 2007. Laddering: how (not) to do things with words. Qualitative Mark. Research: An International Journal, $10,63-77$

TORRES, M., TARREGA, A., TORRESCASANA, E., and BLANCH, C. 2012. Influence of label information on dark chocolate acceptability. Appetite, $58,665-671$ 
VARELA, P., ARES, G., GIMÉNEZ, A., and GÁMBARO, A. 2010. Influence of brand information on consumers' expectations and liking of powered drinks in central location tests. Food Qual. and Prefer. 21, 873-880.

VAZQUEZ, M.B., CURIA, A. and HOUGH, G. 2009. Sensory descriptive analysis, sensory acceptability and expectation studies on biscuits with reduced added salt and increased fiber. J. Sensory Studies, 24, 498-511.

VILLEGAS, B., CARBONELL, I., and COSTELL, E. 2008. Effects of product information and consumer attitudes on responses to milk and soybean vanilla beverages. J. Sci. Food and Agric. 88, 2426-2434.

WILCOCK, A., PUN, M., KHANONA, J., and AUNG, M. 2004. Consumer attitudes, knowledge and behaviour: a review of food safety issues. Trends Food Sci. Technol. 15, 56-66. 



\title{
CAPÍTULO 4
}

\author{
Effect of inulin seeding on rheology \\ and microstructure of prebiotic dairy \\ desserts
}

Food Biophysics, 6 (2011), 440-449 



\title{
Effect of inulin seeding on rheology and microstructure of prebiotic dairy desserts
}

\author{
Patricia L. Arcia ${ }^{1,2}$, Sergio Navarro ${ }^{1}$, Elvira Costell ${ }^{1}$, Amparo Tárrega $^{1}$ \\ ${ }^{1}$ Physical and Sensory Properties Laboratory. Instituto de Agroquímica y Tecnología de Alimentos \\ (CSIC), Avda. Agustín Escardino, 7. 46980 Paterna (Valencia), Spain. \\ ${ }^{2}$ Laboratorio Tecnológico del Uruguay. Av. Italia 6201, C.P. 11500. Montevideo, Uruguay.
}

\begin{abstract}
Long-chain inulin in presence of water forms a particulate gel of inulin crystals that can improve consistency of low-fat products but can also be responsible for a rough sensation. The objective of this work was to study the rheological properties and microstructure of inulin enriched desserts when using seeding to control inulin particle size. Dairy desserts were prepared with $2.5,5$ and $7.5 \%$ of long-chain inulin and during cooling they were seeded with a small amount of powdered inulin. After 1, 4 and 7 days of refrigerated storage the rheological properties and microstructure of samples were studied and compared with control (unseeded) samples. Results indicated that seeding had a significant effect on both rheological properties and microstructure of desserts. For all inulin concentrations, the seeding technique favoured a faster formation of a greater amount and more regular sized inulin particles.
\end{abstract}

Key words: inulin, seeding, rheological properties, microstructure. 


\section{INTRODUCTION}

Inulin is a prebiotic dietary fibre that is included in the formulation of food products due to its nutritional or technological properties ${ }^{1}$.Inulin with a high polymerisation degree can be used as thickener and fat substitute in low-fat foods because in the presence of water inulin form microcrystals which interact with each other, forming small aggregates that can occlude a great amount of water and create a particulate gel ${ }^{2,3}$. Gel characteristics depend on factors such as inulin concentration and processing conditions that affect nucleation, crystallization and the arrangement of inulin crystals. Duynhoven et al. ${ }^{4}$ studied the kinetics of ageing in long-chain inulin gels through NMR cross-relaxation experiments and showed that gel firming takes longer when starting from a totally dissolved inulin solution (heated at temperatures exceeding $82{ }^{\circ} \mathrm{C}$ ). Bot et al. ${ }^{5}$ showed that the inulin crystallisation rate decreased greatly when inulin solution had been heated at temperatures near to dissolution point and Glibowski and Wasko ${ }^{6}$ showed that gelation was inhibited after heating inulin solutions above $80{ }^{\circ} \mathrm{C}$ while at lower temperatures solutions formed firm inulin gels. According to these authors, when an inulin solution is heated and inulin dissolves completely, a longer time must elapse before crystallization begins than for lower preparation temperatures where the presence of crystals acts as a nucleus, facilitating faster overall growth of smaller inulin crystallites. The importance of crystal seeds presence on inulin gel formation was confirmed recently by Glibowski and Pikus ${ }^{7}$ on adding inulin (amorphous or crystalline) to the preheated inulin solution as an alternative to have inulin seeds in products that have to be processed at temperatures above 80 ${ }^{\circ} \mathrm{C}$. The solution inoculated with inulin showed a fast crystallisation and the formation of a stable gel while in the non inoculated solution only precipitation of inulin particles was observed. All these studies have been carried out in water solutions. In dairy desserts enriched with inulin (7.5\%) and prepared with 
thermal treatment, Torres et al. ${ }^{8}$ showed the formation of inulin particles during a seven-day storage period that produced an increase in both viscosity and elasticity of products. By varying inulin chain-length distribution, the characteristics of inulin particles and thus the rheological properties of products can be varied ${ }^{9}$. Seeding has previously been used by producers of condensed milk and "dulce de leche" to control particle size and to avoid the formation of big lactose crystal agglomerates, which are partly responsible for product sandiness ${ }^{10}$. The aim of the present work was to study the effect of inulin seeding on the rheological properties and microstructure of low-fat desserts enriched with different concentrations of long-chain inulin $(2.5,5$ and $7.5 \%)$.

\section{MATERIALS AND METHODS}

\section{Sample composition and preparation}

Samples were prepared using the following ingredients: long-chain inulin (Frutafit ® TEX) (Sensus, Brenntag Química, Spain), skimmed milk powder (Central Lechera Asturiana, Spain), modified tapioca starch $(\mathrm{C} *$ CreamTex 75,720, Cargill, Spain), commercial sucrose, mineral water (Font Vella, Spain) and preservatives: potassium sorbate and potassium benzoate (Panreac, Quimica SA, Spain). Inulin content was varied from $2.5,5$ and $7.5 \%$ while contents of starch $(3.75 \%)$, sucrose $(6 \%)$, milk (80\%), and preservatives (potassium sorbate 500 ppm; potassium benzoate 500 ppm) were constant. Skimmed milk was prepared $24 \mathrm{~h}$ in advance by dissolving milk powder (13.5\%) in mineral water and stored under refrigeration $\left(4 \pm 1{ }^{\circ} \mathrm{C}\right)$. Samples were prepared in batches of 800 g. Starch, sucrose, inulin and milk were weighed in a flask and mixed under magnetic stirring for $10 \mathrm{~min}$. The flask was placed in a water bath at $97 \pm 1{ }^{\circ} \mathrm{C}$ 
and stirred constantly with a propeller stirrer for 25 min (paddle stirrer, Heidolph RZR 1, Germany). Then the sample was cooled in a water bath at $20^{\circ} \mathrm{C}$ with stirring for 10 minutes. When samples reached a temperature of $40^{\circ} \mathrm{C}, 1.6 \mathrm{~g}$ of inulin $(0.2 \%$ of total sample weight) was added as inoculum. Finally the preservatives and the water evaporated in the process were added, and then samples were transferred to closed flasks and stored under refrigeration $\left(4 \pm 1^{\circ} \mathrm{C}\right)$. Desserts with the same total amounts of inulin but without inoculums were also prepared as control samples. Rheological, particle size and microscopy analyses were carried out after 1, 4, and 7 days of storage. Two replicates of each sample were prepared and measured.

\section{Rheological measurements}

All rheological measurements were carried out at $10 \pm 1{ }^{\circ} \mathrm{C}$ with a controlled stress rheometer (RheoStress 1, Karslruhe, Germany), using a parallel-plates sensor system $(6 \mathrm{~cm}$ diameter and $1 \mathrm{~mm}$ gap). Samples were left to relax for 5 min before shearing.

\section{Flow behaviour}

Sample flow was measured by recording shear stress values when shearing the samples at linear increasing shear rates from 1 to $200 \mathrm{~s}^{-1}$ through $60 \mathrm{~s}$ and down in reverse sequence during the same time ${ }^{11}$ using the "controlled rate" mode of the rheometer. Data from the ascending segment of the shear cycle were fitted to the Ostwald-de Waele model (Equation 1) using Rheowin Pro software (version 2.93, Haake).

$$
\sigma=\mathrm{K} \dot{\gamma}^{\mathrm{n}}
$$


where $\mathrm{K}\left(\mathrm{Pa} \cdot \mathrm{s}^{\mathrm{n}}\right)$ is the consistency index and $\mathrm{n}$ is the flow index. Apparent viscosity values at $10 \mathrm{~s}^{-1}$ were calculated using equation 2 .

$$
\eta_{10}=\mathrm{K} \dot{\gamma}^{(\mathrm{n}-1)} \quad \text { for } \quad \dot{\gamma}=10
$$

\section{Viscoelastic properties}

Stress sweeps were run at $1 \mathrm{~Hz}$ to determine the linear viscoelastic region. The frequency sweeps were performed over the range $\mathrm{f}=0.01-10 \mathrm{~Hz}$ and the values of the storage modulus $\left(G^{\prime}\right)$ and the loss modulus $\left(G^{\prime \prime}\right)$, as a function of frequency, were calculated using the Rheowin Pro software (version 2.93, Haake).

\section{Particle size distribution}

Particle size distribution analysis was performed with a Laser Diffraction Particle Size Analyzer (Mastersizer 2000 Malvern Instruments, Worcestershire, UK), connected to a cell for liquid measurements (Hydro 2000S mixing, Malvern Instruments, Worcestershire, UK) with distilled water as dispersant. The refractive index used was 1.53. Particle size calculations were based on the MieScattering theory. The percentage of volume (\% Volume) and mean diameter $(\mathrm{D}[4,3])$ corresponding to each observed population were calculated. Calculations were done with the software provided with the equipment (Mastersizer 2000 V. 5.40). 


\section{Light microscopy}

Samples were placed on slides with a cover slip and observed at a magnification of $20 \mathrm{x}$ under a light microscope (Nikon Eclipse 90i). Photomicrographs were acquired with a digital camera (Nikon DS-5Mc).

\section{Statistical analysis}

The effects of storage time and seeding on the apparent viscosity at $10 \mathrm{~s}^{-1}$ and the values of $\mathrm{G}^{\prime}$ and tan $\delta$ at $1 \mathrm{~Hz}$ were studied for each inulin level by analysis of variance (ANOVA) of two factors with interaction. The Fisher test $(\alpha=0.05)$ was used to calculate the minimum significant difference. Calculations were carried out with XLSTAT-Pro Version 2007 (Addinsoft, Paris, France).

\section{RESULTS}

\section{Rheological behaviour}

Rheological behaviour of seeded and unseeded desserts containing different inulin concentrations was studied during storage time. Flow curves are shown in Figure 1 and in all cases they exhibited a shear thinning flow behaviour with apparent thixotropy.

Flow curves of samples changed during storage differently depending on the concentration of inulin and on seeding (seeded or unseeded sample). In order to characterise the flow behaviour of each sample, data of the ascending curve were fitted to the Ostwald-de Waele model $(0.98 \leq \mathrm{R} \leq 0.99)$ and the values of consistency index (K) and the flow index (n) obtained are shown in Table 1. 
In general, the consistency index values increased during storage while the flow index slightly decreased. On the seventh day of storage, the samples showed consistency index values that varied from 11.1 to $51.1 \mathrm{~Pa}_{\mathrm{s}}^{\mathrm{n}}{ }^{\mathrm{n}}$ and flow index values that were low (from 0.27 to 0.40 ) indicating a high shear thinning behaviour. Consistency values increased with inulin concentration and in general were higher for seeded samples than for unseeded samples. Flow index values decreased with inulin concentration but slightly varied among seeded and unseeded samples. 

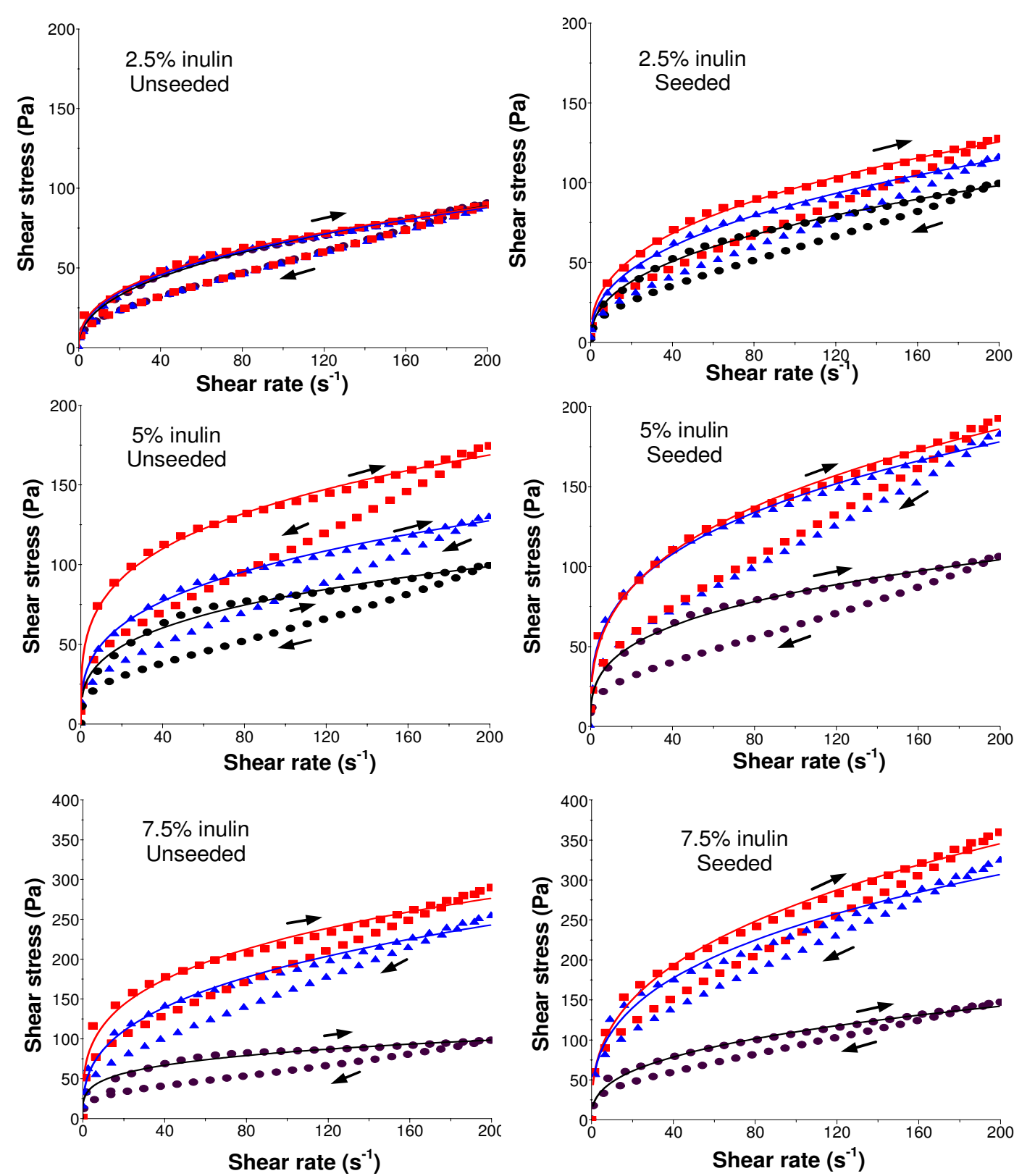

Figure 1. Flow behaviour (upward and downward curves) of inulin-enriched dairy desserts at $10^{\circ} \mathrm{C}$. Fits to Ostwald-de Waele model (-) of the upward curve. Measurements were carried out at different storage time: $1^{\text {st }}(\bullet), 4^{\text {th }}(\mathbf{\Delta})$ and $7^{\text {th }}$ day ( $\square)$. 
Table 1. Characterisation of the flow behaviour of desserts enriched with inulin. Average values and standard deviation $(n=2)$ for the consistency index $(K)$ and flow index (n) obtained from Ostwald- de Waele model.

\begin{tabular}{|c|c|c|c|c|c|c|c|}
\hline \multirow{2}{*}{ Procedure } & \multirow{2}{*}{$\begin{array}{c}\text { Storage } \\
\text { time } \\
\text { (days) }\end{array}$} & \multicolumn{2}{|c|}{$2.5 \%$ inulin } & \multicolumn{2}{|c|}{$5 \%$ inulin } & \multicolumn{2}{|c|}{$7.5 \%$ inulin } \\
\hline & & $\mathrm{K}\left(\mathrm{Pa}_{\mathrm{s}} \mathrm{s}^{\mathrm{n}}\right)$ & $\mathrm{n}$ & $\mathrm{K}\left(\mathrm{Pa} \cdot \mathrm{s}^{\mathrm{n}}\right)$ & $\mathrm{n}$ & $\mathrm{K}\left(\mathrm{Pa} . \mathrm{s}^{\mathrm{n}}\right)$ & $\mathrm{n}$ \\
\hline \multirow{3}{*}{$\begin{array}{c}\text { No } \\
\text { seeding }\end{array}$} & 1 & $9.1(0.3)$ & $0.44(0.01)$ & $20.9(2.0)$ & $0.31(<0.01)$ & $26.5(1.6)$ & $0.35(0.02)$ \\
\hline & 4 & $9.6(0.8)$ & $0.40(0.01)$ & $25.8(2.2)$ & $0.31(<0.01)$ & $29.4(1.1)$ & $0.30(0.03)$ \\
\hline & 7 & $11.0(0.3)$ & $0.40(<0.01)$ & $35.3(3.5)$ & $0.27(0.01)$ & $40.1(0.6)$ & $0.30(<0.01)$ \\
\hline \multirow{3}{*}{ Seeding } & 1 & $10.5(0.9)$ & $0.40(0.01)$ & $23.4(0.3)$ & $0.32(0.01)$ & $35.2(0.5)$ & $0.30(<0.01)$ \\
\hline & 4 & $14.4(0.9)$ & $0.40(<0.01)$ & $32.2(2.7)$ & $0.33(0.01)$ & $49.5(1.6)$ & $0.29(0.01)$ \\
\hline & 7 & $15.8(1.4)$ & $0.38(<0.01)$ & $34.0(2.8)$ & $0.34(0.01)$ & $51.1(1.2)$ & $0.29(0.02)$ \\
\hline
\end{tabular}

To study viscoelastic properties, mechanical spectra of all samples were obtained (Figure 2). The first day, the mechanical spectra of all samples presented values of storage modulus ( $\left.G^{\prime}\right)$ higher than loss modulus ( $G^{\prime \prime}$ ) and both parameters were quite dependent on frequency, indicating a response typical of a weak gel. During storage time, the values of G' and G' 'increased and, in the case of $5 \%$ and $7.5 \%$ inulin samples, became less dependent on frequency indicating an increase in gel strength. 

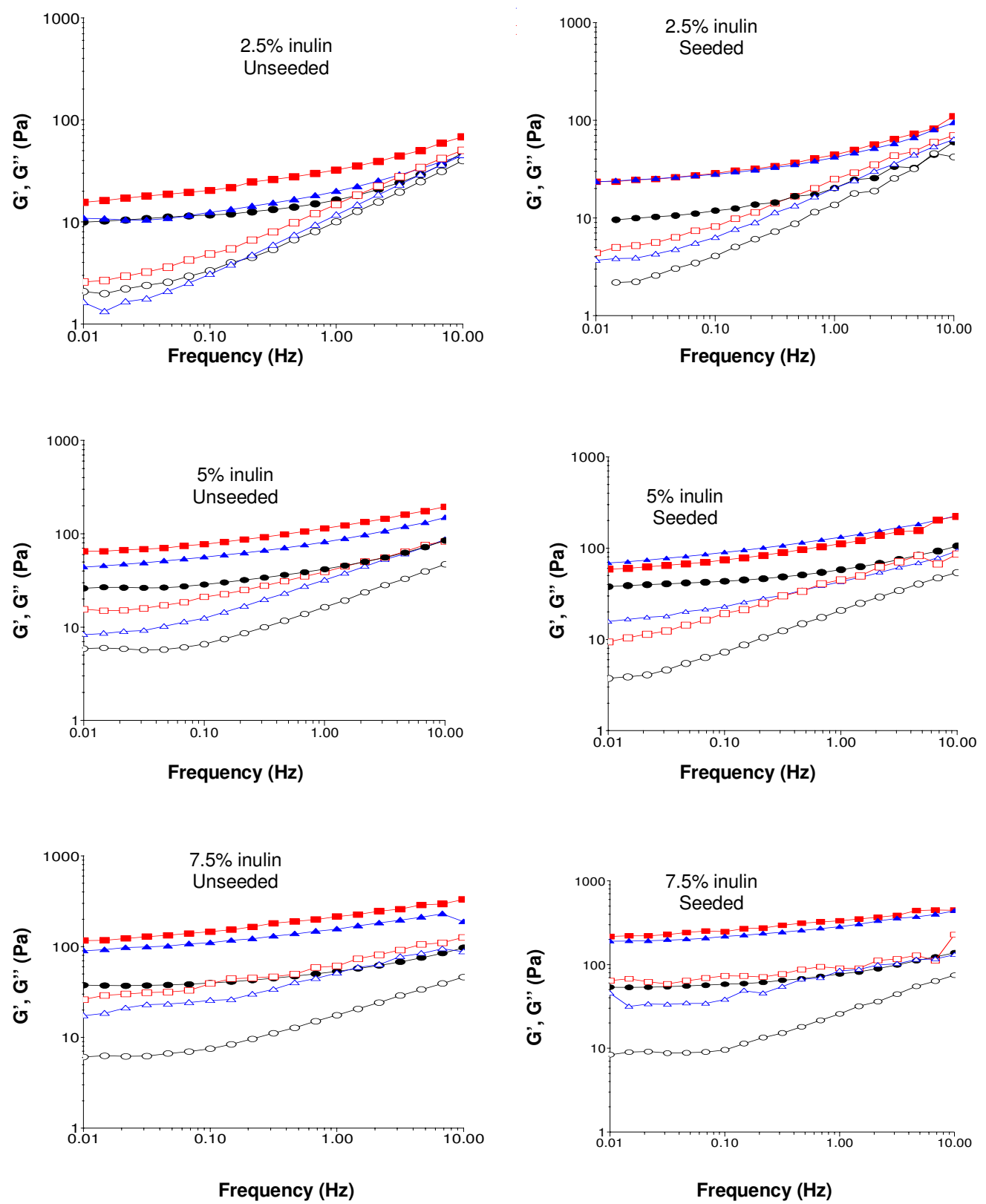

Figure 2. Mechanical spectra of inulin-enriched dairy desserts at $10^{\circ} \mathrm{C}$. Measurements were carried out at different storage time: $1^{\text {st }}(\mathbf{\bullet}), 4^{\text {th }}(\mathbf{\Delta})$ and $7^{\text {th }}$ day ( $\square$ ). Values of G' (filled symbols) and G', (open symbols). 
In order to quantify the changes in rheological properties during storage time and to compare among different desserts, the values of apparent viscosity at $10 \mathrm{~s}^{-1}$ and the values of $\mathrm{G}^{\prime}$ and $\tan \delta$ at $1 \mathrm{~Hz}$ were taken (Figures 3 and 4, respectively).
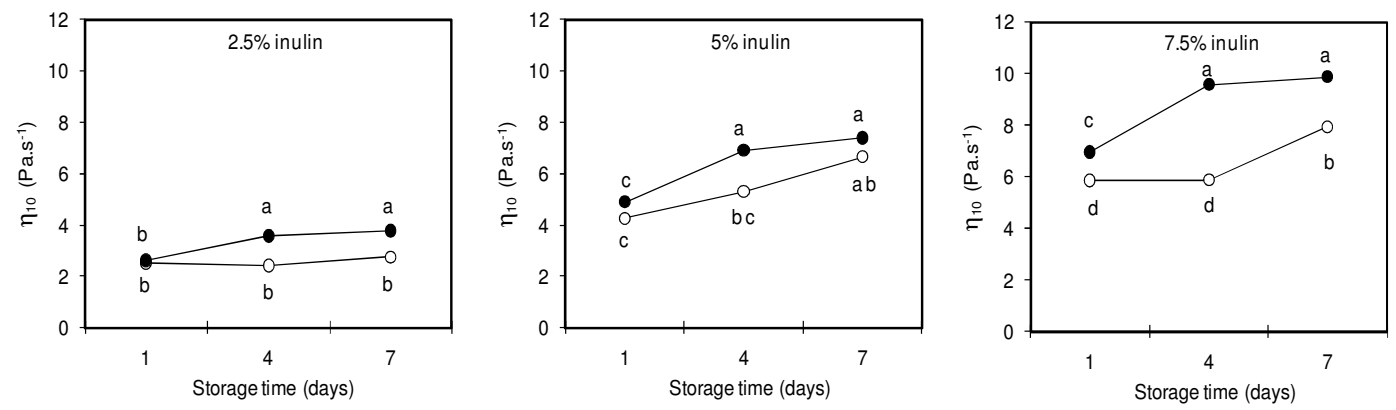

Figure 3. Average values of apparent viscosity at $10 \mathrm{~s}^{-1}\left(\eta_{10}\right)$ for inulin enriched dairy desserts. Significant differences among values are indicated by the letters: values not sharing letters differ significantly $(p=0.05)$. Seeded samples $(\bullet)$ and unseeded samples (०).
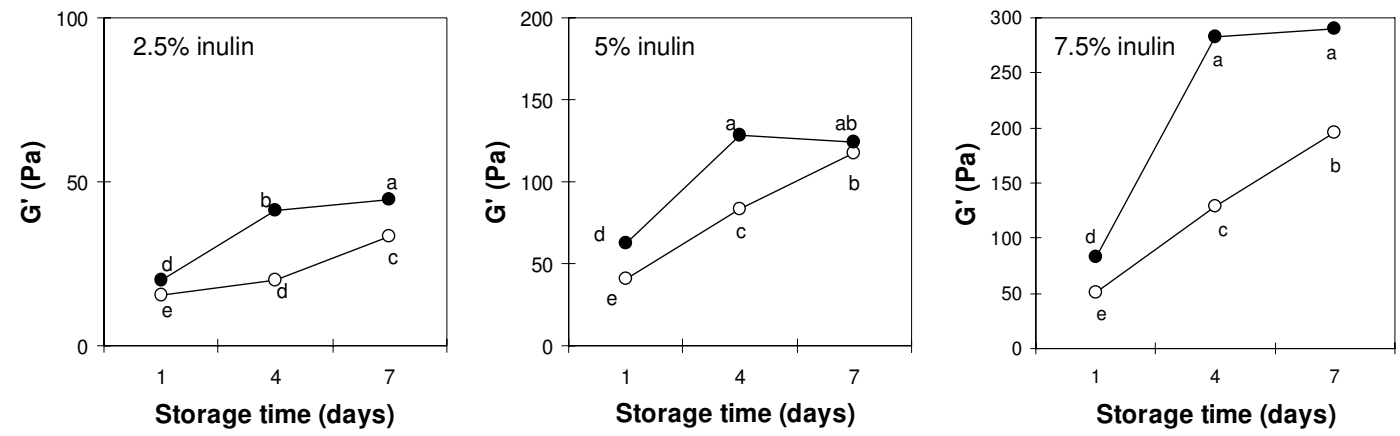

Figure 4. Average values of storage modulus for inulin enriched dairy desserts. Significant differences among values are indicated by the letters: values not sharing letters differ significantly $(p=0.05)$. Seeded samples $(\bullet)$ and unseeded samples (०). 
Generally speaking, viscosity and elasticity of samples increased over time, indicating a reinforcement of the system structure. The magnitude of changes depended on inulin concentration. For samples containing $2.5 \%$ inulin, viscosity values slightly increased (seeded samples) or did not significantly vary (unseeded samples) during storage time while a great variation was observed for samples with 5 and $7.5 \%$ inulin. The increase in storage modulus values during storage time was also low for $2.5 \%$ samples. However tan $\delta$ values significantly decreased during storage for $2.5 \%$ inulin samples, while remained almost constant for 5 and $7.5 \%$ inulin samples (Figure 4). The first day, samples with low amount of inulin showed high $\tan \delta$ values due to the higher amount of water in the continuous phase resulting in a more fluid-like response. During storage, water retention caused by this low amount of inulin slightly increased elasticity but was enough to significantly increase the relative contribution of the storage modulus with respect to the loss modulus. For the three concentrations of inulin, the ANOVA showed a significant interaction between the effects of seeding and storage time on apparent viscosity and storage modulus (Table 2) indicating that variations in both viscosity and elasticity of custards during storage depended on the presence of inulin seeds after thermal treatment. The increase in viscosity and elasticity was higher and faster when seeding procedure was used. On the fourth day of storage, seeded samples already reached the same values as those observed on the seventh day of storage time, while for unseeded samples changes in flow properties continued to occur after the fourth day. This is in agreement with the results observed by Duynhoven, et $a l .{ }^{4}$, who showed gel firming to take longer in the absence of inulin crystal seeds. 
Table 2. Analysis of variance of two factors (seeding and storage time) with interaction on values of apparent viscosity at $10 \mathrm{~s}^{-1}$ and storage modulus at $1 \mathrm{~Hz}$. $\mathrm{F}$ and $\mathrm{p}$ values.

\begin{tabular}{|c|c|c|c|c|c|c|c|c|c|c|c|c|}
\hline \multirow[b]{3}{*}{ Factors } & \multicolumn{6}{|c|}{ Apparent viscosity at $10 \mathrm{~s}^{-1}$} & \multicolumn{6}{|c|}{ Storage modulus at $1 \mathrm{~Hz}$} \\
\hline & \multicolumn{2}{|c|}{$2.5 \%$ Inulin } & \multicolumn{2}{|c|}{$5 \%$ Inulin } & \multicolumn{2}{|c|}{$7.5 \%$ Inulin } & \multicolumn{2}{|c|}{$2.5 \%$ Inulin } & \multicolumn{2}{|c|}{$5 \%$ Inulin } & \multicolumn{2}{|c|}{$7.5 \%$ Inulin } \\
\hline & $\mathrm{F}$ & $\mathrm{p}$ & $\bar{F}$ & $\mathrm{p}$ & $\bar{F}$ & $\mathrm{p}$ & $\bar{F}$ & $\mathrm{p}$ & $\bar{F}$ & $\mathrm{p}$ & $\bar{F}$ & $\mathrm{p}$ \\
\hline $\begin{array}{l}\mathrm{A}: \\
\text { seeding }\end{array}$ & 32.31 & 0.001 & 25.25 & 0.002 & 101.35 & $<0.001$ & 53.37 & 0.000 & 85.77 & $<0.001$ & 430.96 & $<0.001$ \\
\hline $\begin{array}{l}\mathrm{B}: \\
\text { storage } \\
\text { time }\end{array}$ & 8.91 & 0.016 & 57.34 & $<0.001$ & 41.97 & $<0.001$ & 17.77 & 0.003 & 248.01 & $<0.001$ & 568.05 & $<0.001$ \\
\hline $\mathrm{A} \times \mathrm{B}$ & 5.98 & 0.037 & 7.13 & 0.026 & 11.81 & 0.008 & 5.30 & 0.047 & 17.35 & 0.003 & 60.67 & $<0.001$ \\
\hline
\end{tabular}

\section{Microstructure}

Changes in sample microstructure during storage time were checked by observing samples under light microscopy and analysing particle-size distribution. As stated previously ${ }^{8}$, in microscopic images (Figures 5, 6 and 7) big particles corresponded to swollen starch granules, which appeared as a population of particles ranging from 10 to $100 \mu \mathrm{m}$ (figure 8), while inulin particles can be observed at a smaller size range $(<10 \mu \mathrm{m})$. Particle size distribution of $2.5 \%$ inulin samples (data not shown) revealed only the population corresponding to the dispersed swollen starch granules throughout the storage period. However in microscopic images (Figure 5), small inulin particles can be observed. In seeded samples, inulin particles were observed sooner (on the fourth day) than for control samples (on the seventh day). Both the small size and the low abundance of these particles compared with those of starch granules would explain why they were not registered when particle-size distribution was measured. Furthermore, that would also explain the small variation observed in 
the rheological properties of $2.5 \%$ inulin samples. For samples with 5 and $7.5 \%$ inulin, changes in particle-size distribution were observed during storage time (Figure 8). Bimodal distributions were observed, with the population of inulin particles under $10 \mu \mathrm{m}$, for which the mean diameter and occupied volume percentage were calculated (Table 2). It should be noted that these values obtained for inulin particles are influenced by the significantly greater size of starch particles and are valid for comparison among samples since the percentage of the other ingredients in the formulation remained constant.

According to the images of samples with 5\% inulin (Figure 6), very few inulin particles appeared in control samples on the first day, while more appeared in the seeded sample. However, as happened for $2.5 \%$ of inulin samples, these particles were not observed when particle size distribution was analysed (Figure 8). On the fourth day of storage, micrographs showed abundant inulin particles which, according to particle size distribution, were more abundant and smaller in size in the case of seeded sample than in control (Table 3). 

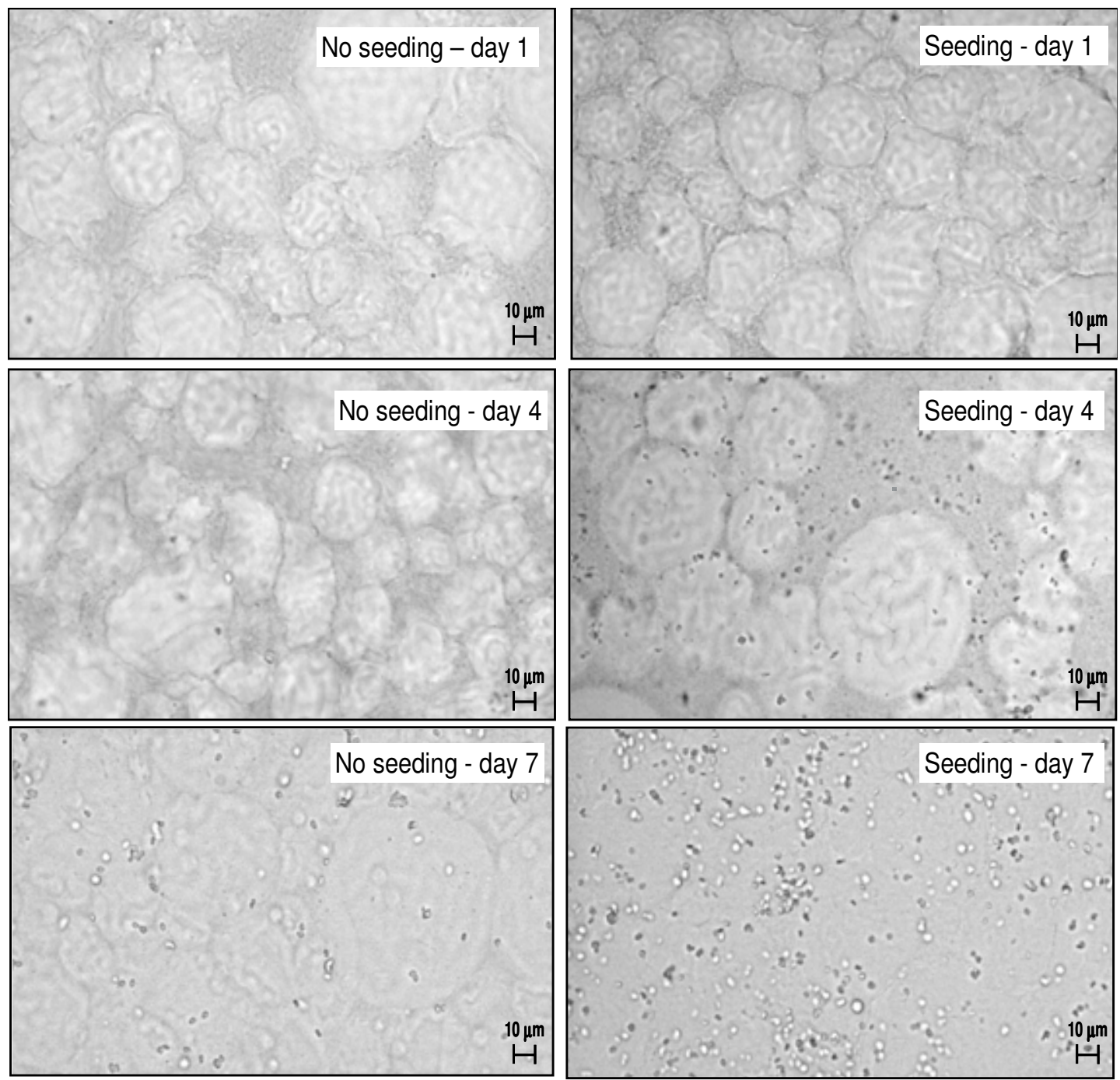

Figure 5. Microscopy images for samples with $2.5 \%$ inulin at different storage time. 

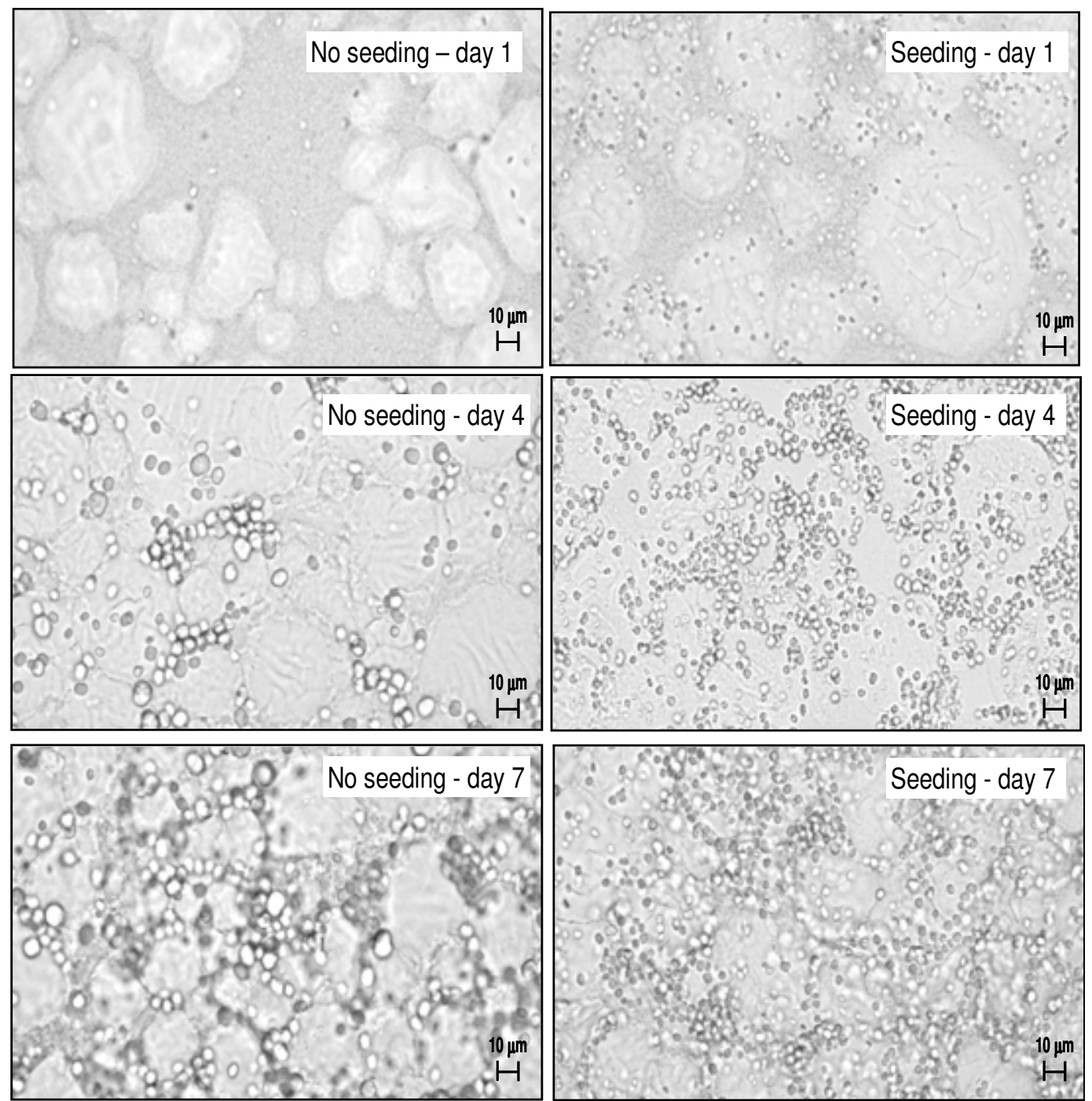

Figure 6. Microscopy images for samples with $5 \%$ inulin at different storage time. 

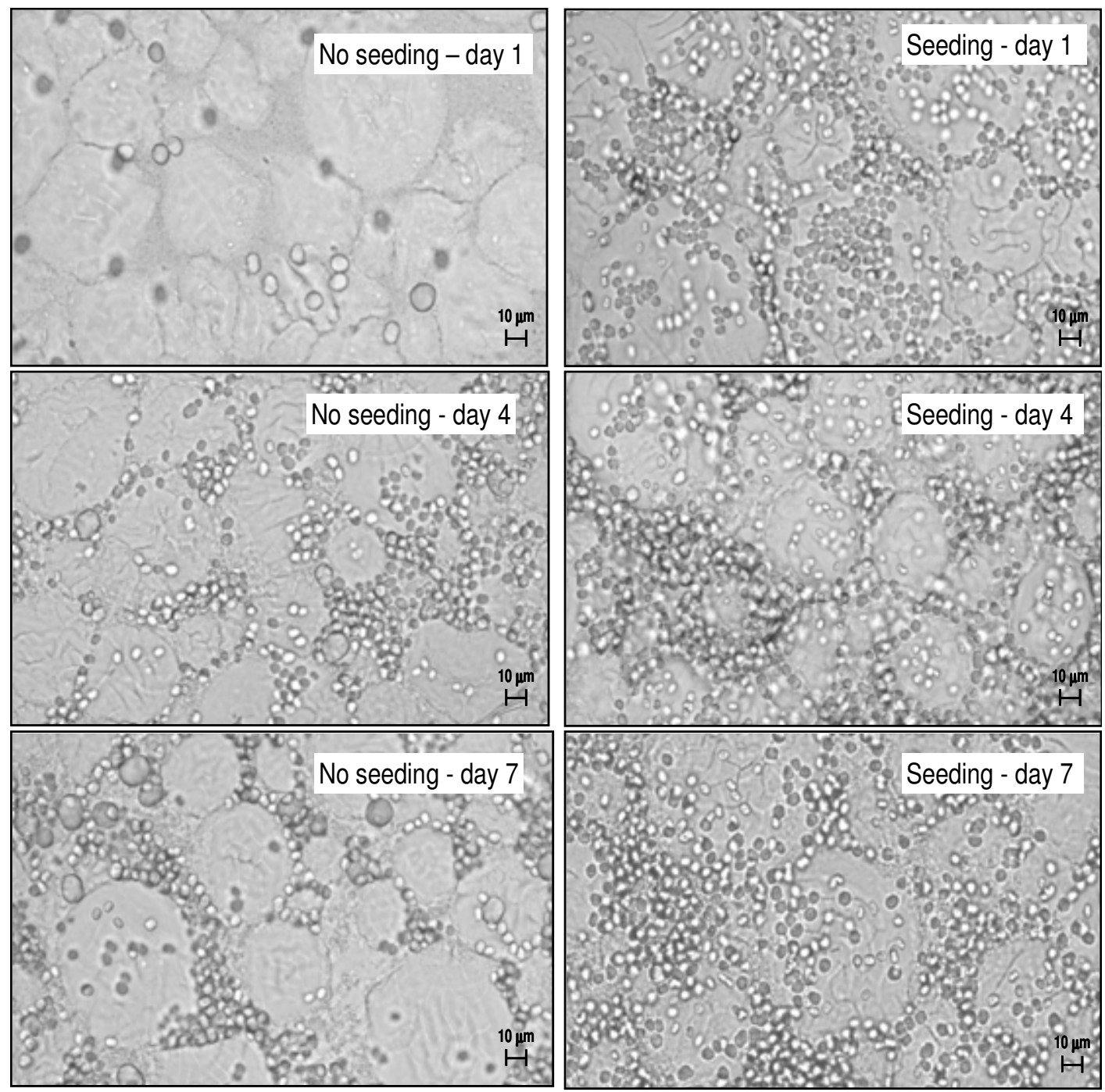

Figure 7. Microscopy images for samples with $7.5 \%$ inulin at different storage time. 
A)
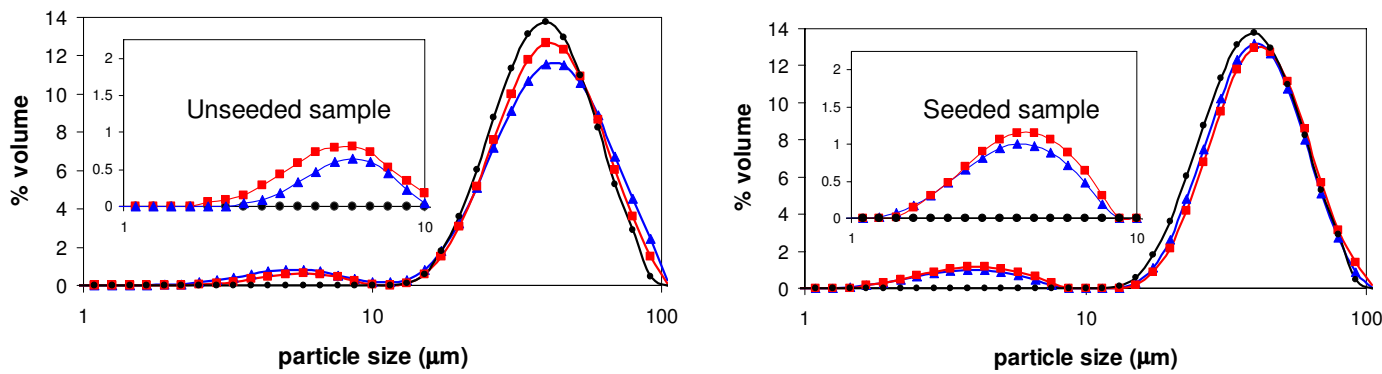

B)
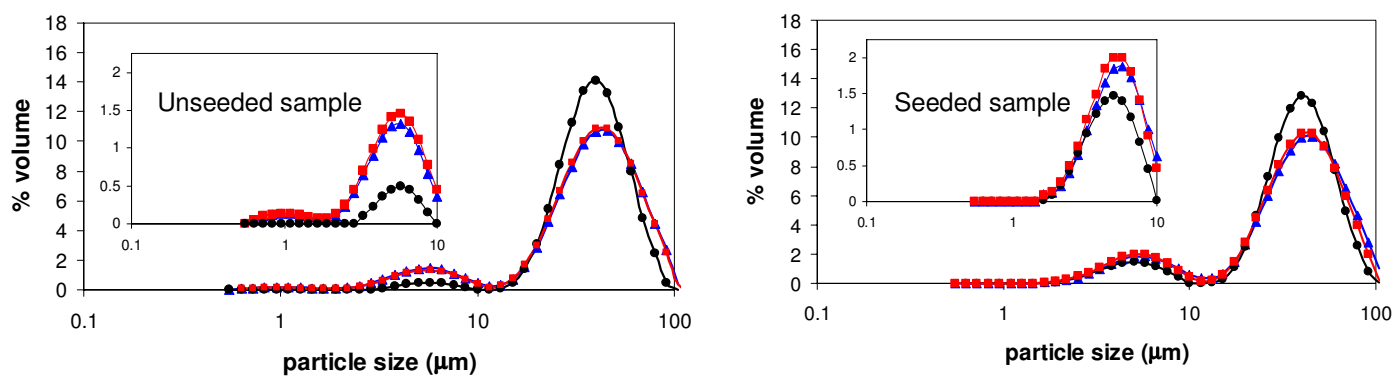

Figure 8. Particle size distribution for samples with 5\% inulin (A) and 7.5\% inulin (B) at different storage time: $1^{\text {st }}(\bullet), 4^{\text {th }}(\mathbf{\Delta})$ and $7^{\text {th }}$ day ( $\left.\square\right)$. 
Table 3. Characteristics of the population of particles with size $<10 \mu \mathrm{m}$ found in desserts enriched.

\begin{tabular}{lccccc}
\hline & \multicolumn{2}{c}{$5 \%$ Inulin } & \multicolumn{2}{c}{$7.5 \%$ Inulin } \\
\hline Procedure & $\begin{array}{c}\text { Storage } \\
\text { time (days) }\end{array}$ & $\%$ volume & $\mathrm{D}[4,3](\mu \mathrm{m})$ & $\%$ volume & $\mathrm{D}[4,3](\mu \mathrm{m})$ \\
\hline \multirow{2}{*}{ No seeding } & 1 & - & - & $2.41^{\mathrm{d}}$ & $5.09^{\mathrm{a}}$ \\
& 4 & $4.75^{\mathrm{c}}$ & $5.12^{\mathrm{a}}$ & $10.46^{\mathrm{c}}$ & $4.07^{\mathrm{bc}}$ \\
& 7 & $6.99^{\mathrm{b}}$ & $4.82^{\mathrm{a}}$ & $11.96^{\mathrm{b}}$ & $4.76^{\mathrm{abc}}$ \\
Seeding & 1 & - & - & $10.33^{\mathrm{c}}$ & $4.49^{\mathrm{c}}$ \\
& 4 & $7.83^{\mathrm{ab}}$ & $3.89^{\mathrm{b}}$ & $15.53^{\mathrm{a}}$ & $4.77^{\mathrm{abc}}$ \\
& 7 & $8.71^{\mathrm{a}}$ & $4.00^{\mathrm{b}}$ & $15.35^{\mathrm{a}}$ & $4.91^{\mathrm{ab}}$ \\
\hline
\end{tabular}

For each column values not shearing letters differ significantly $(p=0.05)$.

From the $4^{\text {th }}$ to $7^{\text {th }}$ day, the increase in particle number was only significant for the control sample. On the seventh day the seeded sample still showed higher particle number and with lower size than the control. For samples with $7.5 \%$ inulin, on day one, the seeded sample revealed a great amount of inulin aggregates (10.33\% of volume) with regular size. The percentage of volume occupied by these particles also increased during storage time and its size increased slightly and uniformly. On day one, control sample revealed few largesized particles and during storage time small particles appeared, which lowered the mean diameter value. As a result, seeded and unseeded samples showed no differences in the mean diameter values $\left(D_{4,3}\right)$; however, they were more regular in size in the seeded samples.

According to this result, the changes in dessert microstructure during storage time were highly dependent on inulin concentration. Furthermore, the changes in inulin particle size during storage time differed for seeded and control samples, indicating that different phenomena occurred. In the case of unseeded samples, inulin particles appeared later because inulin was completely dissolved during heating (above $85^{\circ} \mathrm{C}$ for $15 \mathrm{~min}$ ) and in this situation, spontaneous nucleation 
takes longer. Furthermore, two different nucleation steps were observed in unseeded samples, the first leading to large particles and the second leading to smaller ones. The formation of different shaped and sized inulin particles has previously been observed under different conditions and described by different authors. Hebette et al. ${ }^{2}$ showed that inulin solutions heated at $96{ }^{\circ} \mathrm{C}$ during cooling presented two nucleation steps, the first at high temperatures, yielding 8like shaped particles, and the second nucleation occurring at lower temperatures yielding smaller inulin particles. According to the authors, crystallites from the first nucleation had more time to grow at higher inulin concentrations and were growing at higher temperatures, where diffusion of molecules to the crystal surface was faster. Bot et al. ${ }^{5}$ observed that, in inulin dispersions heated to high temperatures, slow crystallisation led to large primary particles and a very soft structure. According to the aforementioned authors, the large primary particles formed after removal of any seeding crystals had a low surface-to-mass ratio and, therefore, relatively few connection points, apparently leading to soft gels.

Regarding the seeded samples, inulin particles appeared sooner because inulin seeds initiated crystallisation ${ }^{7}$. Contrary to that observed for unseeded samples, only one nucleation of many small particles occurred, and during storage time particle size grew slightly and homogeneously, reaching a size that depended on the amount of inulin present in the system. Similar differences among seeded and spontaneous crystallisation of lactose were observed in "dulce de leche" by Gimenez et al. ${ }^{10}$. Big crystal agglomerates and small crystals were obtained when crystallised spontaneously and only small crystals formed when lactose crystal seeds were added.

Finally it should be indicated that inulin crystallization is a complex phenomenon, depending on many factors, particularly the thermo-mechanical conditions used during manufacture ${ }^{5}$. In the present work, samples were prepared following a single method; however, during preliminary tests the preparation 
procedure was varied and, although not quantified, cooling rate, shearing rate during cooling and storage flask volume were all found to affect crystallisation rate, inulin particle size and rheological properties, particularly in the case of seeded samples. Results of the present work showed that seeding can be used to control inulin particle size in real food but the effects of these factors must be studied in each case to obtain the desirable amount and size of inulin particles in the product.

\section{CONCLUSION}

Addition of inulin caused changes in rheological properties and microstructure of dairy desserts that highly depended on inulin concentration. For all inulin concentrations, the presence of inulin seeds favoured a faster crystallisation of a greater amount and more regular sized inulin particles, which generally resulted in more viscous and elastic desserts. Seeding proved effective for preparing lowfat custard desserts with regular sized inulin particles, whose abundance and size depend on inulin concentration.

\section{ACKNOWLEDGEMENTS}

To MICINN of Spain for financial support (AGL 2007-63444) and for financing author Tarrega (Juan de la Cierva programme. To CHR Hansen S.A., Lucta S.A., Brenntag Quimica and Central Lechera Asturiana for providing free samples of the ingredients. Authors acknowledge the technical support from J.Gimeno for microscopy analysis. 


\section{REFERENCES}

1. A. Franck, Brit J Nutr87(2): S287-S291 (2002)

2. C. L. M. Hébette, J. A. Delcour, M. H. J. Koch, K. Booten, R. Kleppinger, N. Mischenkod, Carbohyd Res, 310, 65-75 (1998)

3. E. Chiavaro, E. Vittadini, C. Corradini, Eur Food Res Technol, 225, 85-94 (2007)

4. J. P. M. Duynhoven, A. S. Kulik, H. R. A. Jonker, J. Haverkamp, Carbohyd Polym, 40, 211-219 (1999)

5. A. Bot, U. Erle, R. Vreeker, W. G. M. Agterof, Food Hydrocoll, 18(4): 547556 (2004)

6. P. Glibowski, A. Wasko, Int J Food Sci Tech, 43, 2075-2082 (2008)

7. P. Glibowski, S. Pikus, Carbohyd Polym, 83, 635-639 (2011)

8. J. D. Torres, A. Tarrega, E. Costell, Int Dairy J, 20(1): 46-52 (2010)

9. A. Tarrega, J. D. Torres, E. Costell, J Food Eng. Available online 8 January 2011. Article in Press (2011)

10. A. Giménez, G. Ares, A. Gámbaro, J Sens Stud, 23, 171-185 (2008)

11. A. Tarrega, E. Costell, J Food Eng, 78(2), 655-661 (2007) 


\title{
CAPÍTULO 5
}

\author{
Thickness suitability of prebiotic dairy \\ desserts: Relationship with rheological \\ properties
}

Food Research International, 43 (2010), 2409-2416 



\title{
THICKNESS SUITABILITY OF PREBIOTIC DAIRY DESSERTS: RELATIONSHIP WITH RHEOLOGICAL PROPERTIES
}

\author{
P. L. Arcia ${ }^{\mathrm{a}, \mathrm{b}}$, E. Costell $^{\mathrm{a}}$, A. Tárrega ${ }^{\mathrm{a}^{*}}$ \\ ${ }^{a}$ Physical and Sensory Properties Laboratory. Instituto de Agroquímica y Tecnología de \\ Alimentos, CSIC. P.O. Box 73, 46100 Burjassot (Valencia), Spain. \\ ${ }^{\mathrm{b}}$ Laboratorio Tecnológico del Uruguay. Av. Italia 6201, C.P. 11500. Montevideo, Uruguay.
}

\begin{abstract}
In food product development it is important to know to what extent changes in formulation modifies the product, affecting its sensory properties and acceptability. Addition of polysaccharides like inulin can affect product structure in particular, modifying both rheological behaviour and perceived texture. The aim of this work was to assess to what extent rheological properties can explain the acceptability of thickness perceived by consumers in starch-based desserts. Low-fat dairy desserts were prepared varying the concentration of sucrose, flavor aroma and the fat replacer with prebiotic properties (inulin) but with fixed amounts of skimmed milk and starch. The rheological behaviour was characterized and the level of sample thickness suitability was evaluated by a total of 100 consumers using a 5-point JAR scale $(1=$ too weak, $3=$ just about right; $5=$ too strong). Results indicated that flow and viscoelastic parameters varied among samples depending on inulin and sucrose concentration. According to sensory results, thickness suitability varied greatly between samples. The relationships between instrumental and sensory results are studied and discussed.
\end{abstract}

Key words: inulin, rheology, adequacy of thickness, JAR 


\section{INTRODUCTION}

Functional product development provides an opportunity to contribute to the improvement of food quality and consumer health and well-being (Hasler, 1998; Milner, 1999). A common approach employed in the food industry to develop these kinds of added-value foods involves the addition of a healthy component. It is important to know to what extent this new component modifies the product, affecting its sensory properties. In the case of macromolecules such as polysaccharides or proteins, changes in composition can affect product structure in particular, modifying both rheological behaviour and perceived texture (Dickinson, 2007; Purwanti, van der Goot, Boom, \& Vereijken, 2010).

For liquid and semisolid products, thickness is the textural attribute that most influences consumer response, though smoothness and creaminess are also influential (de Wijk, van Gemert, Terpstra, \& Wilkinson, 2003; González-Tomás \& Costell, 2006). In semisolid products with complex rheological behaviour (thixotropy, pseudoplasticity and viscoelasticity), studies aimed at identifying the physical stimuli responsible for thickness perception have proposed different indexes (Van Vliet, 2002). The initial resistance to flow (yield stress value), storage modulus at $1 \mathrm{~Hz}$ (Tárrega \& Costell, 2007) and the complex viscosity at $50 \mathrm{rad}^{-1}$ (Richardson, Morris, Ross-Murphy, Taylor, \& Dea, 1989; Hill, Mitchell, \& Sherman, 1995) have shown significant correlations with thickness intensity. However one must recognize that acceptability may not always be directly related with sensory attribute intensity but rather with its adequacy (Costell, Tárrega, \& Bayarri, 2010). Traditionally, perceptible differences in food attributes are evaluated using sensory descriptive analysis by trained judges while hedonic aspects are evaluated separately by consumers. JAR scale is an alternative method that combines both intensity attribute and hedonics assessed by consumers (Gacula, Rutenbeck, Pollack, Resurreccion, \& Moskowitz, 2007). 
This technique provides information on how consumers feel about the product attribute and then determines both the adequate attribute level for this product and how much a sample deviates from this ideal point.

Inulin is a very interesting functional ingredient that is increasingly being used to formulate new fibre-enriched products or with prebiotic benefits (Roberfroid, 2007). Chemically it is a polymer of fructose units that can have different chain lengths. Long-chain inulin can modify texture because it crystallises in presence of water forming a particle network structure (Chiavaro, Vittadini, \& Corradini, 2007; Hébette, Delcour, Koch, Booten, Kleppinger, \& Mischenkod, 1998). Consequently it is being used in low-fat products to improve creaminess and consistency, mimicking those of full-fat products (Paseephol, Small, \& Sherkatl, 2008; Tárrega \& Costell, 2006; Soukoulis, Lebesi, \& Tzia, 2009; GonzalezTomas, Bayarri, Coll-Marqués, \& Costell, 2009). Nutritional studies have recommended the combination of inulin with different chain lengths in order to maximise its fermentative and prebiotic effects (Biedrzycka \& Bielecka, 2004; Coudray, Tressol, Gueux, \& Rayssiguier, 2003). From a technological viewpoint the use of mixed-chain inulin, instead of only long-chain inulin, may decrease its thickening ability. Tárrega, Rocafull, \& Costell (2010) showed that $7.5 \%$ of a mixture of short and long chain inulin 50:50 was still able to modify the rheological properties of a low-fat dairy dessert. However this effect can also depend on inulin concentration (Bayarri, Chuiliá, \& Costell, 2010) and on its possible interaction with other ingredients and their concentrations. Sucrose is a common ingredient used as sweetener in dairy dessert. In starch based systems whose characteristics depend on interactions between starch and water, the presence of sucrose that reduces both water activity and translational mobility of water can affect gelatinization temperature, starch granules swelling or viscosity (Kohyama, \& Nishinari, 1991; Kurger, Ferrero, \& Zaritzky, 2003). It is expected 
that structure and rheological behaviour of starch-inulin-sucrose systems will be determined by water competition among this three components.

Some studies in the literature indicate that addition of aroma compounds can modify rheological behaviour of food products (Cayot, Lafarge, Arvisenet, \& Taisant, 2000; Lubbers \& Decourcelle, 2004). In starch based desserts (Cayot et al., 2000) addition of different aroma compounds (limonene, ethyl vanillin or isoamyl acetate) resulted in slightly weaker gels that was attributed to the interaction among aroma compound and amylopectin fraction. Other authors have also observed that perceived texture can be affected by aroma compounds through perceptual cross-modal interaction flavour-texture (Bult, De Wijk, \& Hummel, 2007).

The present work aims to study the effect of composition on the rheological behaviour and thickness adequacy in a prebiotic dairy dessert and to establish whether the desirable level of thickness can be explained by rheologicalparameter variation.

\section{MATERIAL AND METHODS}

\section{Sample composition and preparation}

Samples were prepared using the following ingredients: skimmed milk powder (Central Lechera Asturiana, Spain), modified tapioca starch with a medium crosslinking degree $(\mathrm{C} *$ CreamTex 75,720 . Cerestar, Spain), two types of inulin: long-chain (Frutafit ${ }^{\circledR}$ TEX) and short-chain (Frutafit ${ }^{\circledR}$ CLR) (Sensus, Brenntag Química, Spain), commercial sucrose, lemon flavor 16508A (Lucta SA, Spain), colorant T-PT8 - WAS, solution of curcumin from turmeric root in polysorbate (CHR Hansen SA, Spain), mineral water (Font Vella, Spain) and preservatives: potassium sorbate and potassium benzoate (Panreac, Quimica SA, Spain). 
In the formulation of samples, contents of starch (3.75\%), milk (75\%), colorant (37.5 ppm) and preservatives (potassium sorbate $500 \mathrm{ppm}$; potassium benzoate $500 \mathrm{ppm})$ were constant, while inulin, sucrose and lemon flavor were defined according to a three-factor central composite design with replicates of the central point. It comprised nineteen points: eight factorial, six axial and five central points (Table 1).

Skimmed milk (0.11 g fat/100g) was prepared $24 \mathrm{~h}$ in advance by dissolving milk powder $(14.4 \%)$ in mineral water and storing under refrigeration $\left(4 \pm 1^{\circ} \mathrm{C}\right)$. Inulin used corresponded to a mixture of long-chain and short-chain inulin in a ratio of 50:50.

Samples were prepared in batches of $800 \mathrm{~g}$. Starch, sucrose, inulin, and colorant at $20^{\circ} \mathrm{C}$ and milk at $6^{\circ} \mathrm{C}$ were weighed in a flask and mixed under magnetic stirring (paddle stirrer, Heidolph RZR 1, Germany) for $10 \mathrm{~min}$ at approximately $20^{\circ} \mathrm{C}$. The flask was placed in a water bath at $97 \pm 1{ }^{\circ} \mathrm{C}$ and stirred constantly with a propeller stirrer for $25 \mathrm{~min}$. Then the sample was cooled in a water bath at $20^{\circ} \mathrm{C}$ with stirring for 10 minutes. A small portion of long-chain inulin $(0.2 \%$ of total weight of sample), was added during cooling. This "seeding" procedure has been shown to favour the formation of more uniform sized inulin crystals in a preliminary study. Finally the lemon flavour, preservatives and the water evaporated during the process were added, and then samples were transferred to closed flasks and stored in refrigeration $\left(4 \pm 1^{\circ} \mathrm{C}\right)$ for 96 hours before being evaluated. 
Table 1. Experimental design and composition for samples of low-fat dairy dessert.

\begin{tabular}{|c|c|c|c|}
\hline Sample & Sucrose $\%$ & Lemon flavor ppm & Inulin $\%$ \\
\hline 1 & 7 & 75 & 4.5 \\
\hline 2 & 13 & 75 & 4.5 \\
\hline 3 & 7 & 175 & 4.5 \\
\hline 4 & 13 & 175 & 4.5 \\
\hline 5 & 7 & 75 & 7.5 \\
\hline 6 & 13 & 75 & 7.5 \\
\hline 7 & 7 & 175 & 7.5 \\
\hline 8 & 13 & 175 & 7.5 \\
\hline 9 & 10 & 125 & 6 \\
\hline 10 & 4 & 125 & 6 \\
\hline 11 & 16 & 125 & 6 \\
\hline 12 & 10 & 25 & 6 \\
\hline 13 & 10 & 225 & 6 \\
\hline 14 & 10 & 125 & 3 \\
\hline 15 & 10 & 125 & 9 \\
\hline $16-19^{\mathrm{a}}$ & 10 & 125 & 6 \\
\hline
\end{tabular}

\section{Rheological measurements}

All rheological measurements were carried out in a controlled stress rheometer (RheoStress 1, Karslruhe, Germany), monitored by a Rheowin Projob Manager, using a parallel-plates sensor system (6 $\mathrm{cm}$ diameter and $1 \mathrm{~mm}$ gap). During measurements, temperature was kept constant at $10 \pm 1^{\circ} \mathrm{C}$ using a Phoenix P1 Circulator device (Thermo Haake). At least two batches of each composition were prepared and one measurement was performed on each batch. 
Flow behaviour was measured by recording shear stress values $(\sigma)$ when shearing the samples at linearly increasing shear rates $(\dot{\gamma})$ from 1 to $200 \mathrm{~s}^{-1}$ through $60 \mathrm{~s}$ and down in reverse sequence for the same duration. Areas under the upstream $\left(A_{\text {up }}\right)$ and under the downstream $\left(A_{\text {down }}\right)$ as well as the thixotropic area $\left(A_{\text {up }}-A_{\text {down }}\right)$ were obtained.

Upstream data were fitted to the Ostwald-de Waele model $\left(\sigma=K_{\gamma^{n}}\right)$ using Rheowin Pro data software (version 2.93, Haake). In the model K corresponds to the consistency index in Pa.s and $\mathrm{n}$ corresponds to the flow index (dimensionless).

Viscoelastic properties were measured using small amplitude oscillatory shear tests. First, to determine the linear viscoelastic region, stress sweeps were run at $1 \mathrm{~Hz}$. After that, the frequency sweeps were performed over the range $\mathrm{f}=0.1-10$ $\mathrm{Hz}$ and the values of the storage modulus $\left(\mathrm{G}^{\prime}\right)$, the loss modulus ( $\mathrm{G}^{\prime}$ '), the loss tangent angle $(\tan \delta)$ and the complex viscosity $\left(\eta^{*}\right)$, as a function of frequency, were calculated using the Rheowin Pro software (version 2.93, Haake).

\section{Sensory evaluation}

Sensory evaluation was carried out in a standardized test room (ISO, 2007) in morning sessions. Samples $(40 \mathrm{ml})$ were served at $10 \pm 1^{\circ} \mathrm{C}$ in white plastic cups coded with random three-digit numbers. Samples evaluated in each session were served in an order following a Williams design (MacFie, Bratchell, Greenhoff, \& Vallis, 1989).

A total of 100 consumers were recruited by a local consumer association (AVACU) through a short questionnaire sent by mail. They were selected according to the following criteria: age (18 to 65), gender (woman and man) and consumers of semisolid dairy products like custard and/or yoghurt (at least one 
time at week). Demographic characteristics and consumption habits of participants are shown in Table 2 and Table 3, respectively.

Each consumer evaluated the nineteen samples over four sessions ( 4 or 5 samples per session). They were asked to rate the adequacy of sample thickness on a 5point just about right $(\mathrm{JAR})$ scale $(1=$ too weak, $3=$ just about right; $5=$ too strong). Between samples mineral water and bread were provided to consumers to rinse their mouths. Data were collected using the Compusense ${ }^{\circledR}$ five 5.0 software (Compusense Inc., Guelph, Ontario, Canada).

Table 2. Demographic and sociological characteristics of consumers $(n=100)$.

\begin{tabular}{llc}
\hline Characteristic & Category & Consumers (\%) \\
\hline \multirow{2}{*}{ Gender } & Female & 65 \\
& Male & 35 \\
Age (years) & $18-30$ & 52 \\
& $31-45$ & 29 \\
& $>46$ & 19 \\
Marital status & Single & 57 \\
& Married & 38 \\
& Other & 5 \\
Ocupattion & Employee & 52 \\
& Student & 37 \\
& Other & 11 \\
\hline
\end{tabular}


Table 3. Frequency of consumption of different dairy products by participants.

\begin{tabular}{lccc}
\hline & \multicolumn{3}{c}{ \% population } \\
\cline { 2 - 4 } & Last month & Last week & Never \\
\hline Yogurt with regular fat content & 32 & 33 & 35 \\
Yogurt 0\% fat & 21 & 54 & 25 \\
Yogurt 0\% sugar & 23 & 31 & 46 \\
Yogurt with fruit & 20 & 54 & 26 \\
Yogurt with fibre & 26 & 24 & 50 \\
Yogurt with probiotic & 28 & 35 & 37 \\
Ice cream with regular fat content & 32 & 31 & 37 \\
Custard or similar dessert & 28 & 53 & 19 \\
\hline
\end{tabular}

\section{Data analysis}

Variability in rheological parameters was studied by one way analysis of variance (ANOVA) and the significance of differences between samples was determined using the Fisher test $(\alpha \leq 0.05)$. XLSTAT-Pro Version 2007 (Addinsoft, Paris, France) was used.

In order to relate the studied variables with concentration, data were subjected to a multivariate regression analysis and fitted to a second-order model equation provided in the design given by RSM (Gacula, 1993):

$$
\mathrm{Y}=\mathrm{B}_{0}+\mathrm{B}_{1} \mathrm{X}_{1}+\mathrm{B}_{2} \mathrm{X}_{2}+\mathrm{B}_{3} \mathrm{X}_{3}+\mathrm{B}_{11} \mathrm{X}_{1}^{2}+\mathrm{B}_{22} \mathrm{X}_{2}^{2}+\mathrm{B}_{33} \mathrm{X}_{3}^{2}+\mathrm{B}_{12} \mathrm{X}_{12}+\mathrm{B}_{13} \mathrm{X}_{13}+\mathrm{B}_{23} \mathrm{X}_{23}+\text { Error }
$$

where $\mathrm{Y}$ is the studied variable, $\mathrm{B}_{0}$ is the intercept (constant), $\mathrm{B}_{1}, \mathrm{~B}_{2}, \mathrm{~B}_{3}$ the linear, $\mathrm{B}_{11}, \mathrm{~B}_{22}, \mathrm{~B}_{33}$ the quadratic and $\mathrm{B}_{12}, \mathrm{~B}_{13}, \mathrm{~B}_{23}$ the interaction effects, $\mathrm{X}_{1}, \mathrm{X}_{2}$ and $\mathrm{X}_{3}$ the independent variables: concentrations of sucrose, lemon flavor and inulin respectively. In the selected models, only the statistically significant 
parameters at $\mathrm{p} \leq 0.05$ were included based on the Student's test. Statgraphics Plus v. 4.1 (Statistical Graphics Corp. Warrenton, VA, USA)

To analyse data obtained with the JAR scale, first the percentage of consumers rating the thickness of sample in each point of scale was calculated. Secondly, the approach proposed by Gacula et al. (2007) was followed, estimating below and above deviations from point 3 on the scale (JAR). Individual scale scores (1, 2, 3, 4 or 5) were transformed to $(-2,-1,0,1$ or 2 , respectively). Two groups of data emerge from this calculation, one for those consumers who feel that the sample lacks the attribute (below the JAR) and another for those consumers who feel the product exceeds the attribute (above the JAR). For each sample, the mean of values below JAR point 3 corresponded to the negative deviation value (too little of the attribute) and the mean of values above JAR point 3 correspond to the positive deviation value (too much of the attribute).

\section{RESULTS AND DISCUSSION}

\section{Rheological properties. Effect of composition}

All samples displayed time-dependent and pseudoplastic flow behavior, as can be seen in Fig. 1, where some of the flow curves are shown as an example. This is the typical behavior observed in semisolid starch-based products (Doublier \& Durand, 2008; Tarrega \& Costell, 2007) and it corresponds to the deformation resistance of the biphasic structure, given by the characteristics of the dispersed phase (starch granules) and the continuous phase (Nguyen, Jensen, \& Kristensen., 1998; Thebaudin, Lefebvre, \& Doublier, 1998). Fig. 1 also shows that there are quantitative differences among desserts with different inulin, sucrose and lemon flavor concentrations. This is in accordance with previous studies in dairy desserts, 
showing that the compounds included in the continuous phase, such as some components of milk (Matser \& Steeneken, 1997), sucrose (Sikora, Mazurkiewicz, Tomasik, \& Pielichowski, 1999; Acquarone \& Rao, 2003) or different hydrocolloids (Tecante \& Doublier, 1999; Liu, Eskin, \& Cui, 2003; Kruger, et al, 2003) can modify the structure of the system and thus its rheological behaviour. Flow time dependence was evaluated by calculating the thixotropic area and the upward flow curve data were fitted to the Ostwald-de Waele model $\left(0.976 \leq R^{2} \leq\right.$ 0.998). To compare samples, the values of the thixotropic area, consistency index, flow index and apparent viscosity values at $10 \mathrm{~s}^{-1}$ were used (Table 4).

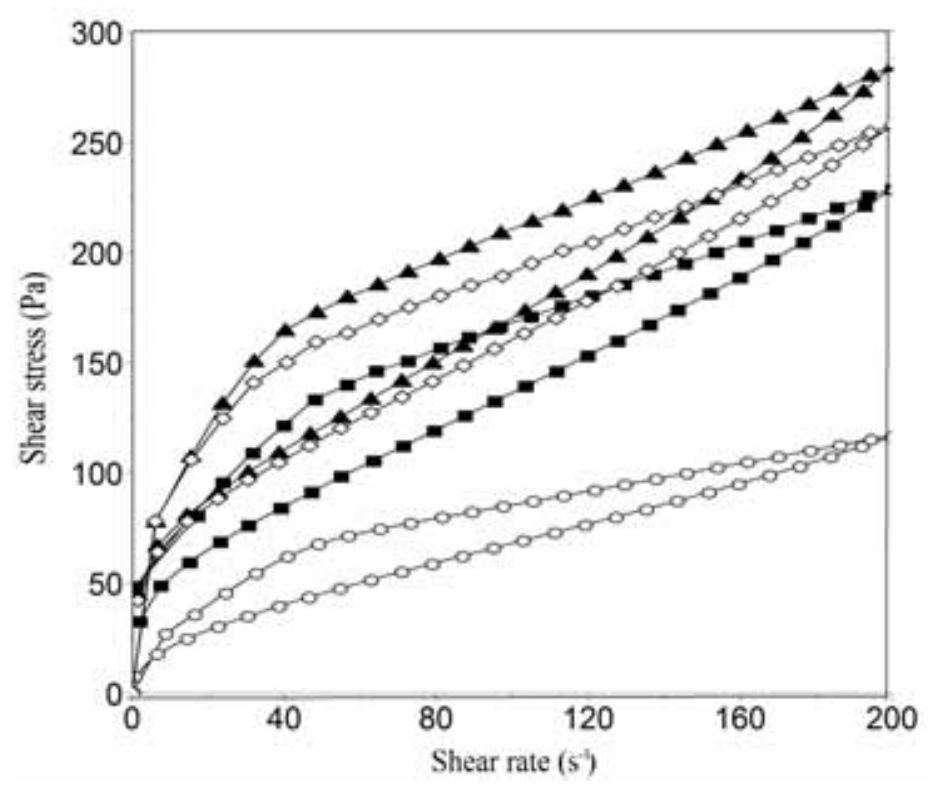

Figure 1. Flow curves of samples: $1(0), 9(\boldsymbol{\square}), 11(\boldsymbol{\Delta})$ and $15(\diamond)$. Identification of samples in Table 1. 
Table 4. Mean values $(n=2)$ for the rheological parameters of dairy desserts ${ }^{1}$. Identification of samples in Table 1.

\begin{tabular}{|c|c|c|c|c|c|c|}
\hline Sample & $\begin{array}{l}\text { Thixotropic Area } \\
\left(\text { Pa. }^{-1}\right)\end{array}$ & $\begin{array}{c}\mathrm{k} \\
\left(\mathrm{Pa} \cdot \mathrm{s}^{\mathrm{n}}\right)\end{array}$ & $\mathrm{n}$ & $\begin{array}{c}\eta_{10} \\
(\text { Pa.s) }\end{array}$ & $\begin{array}{l}\mathrm{G}^{\prime} \\
(\mathrm{Pa})\end{array}$ & $\tan \delta$ \\
\hline 1 & $3513^{\mathrm{de}}$ & $14.0^{\mathrm{d}}$ & 0.41 & $3.60^{\mathrm{d}}$ & $27.9^{\mathrm{d}}$ & $0.69^{\mathrm{abc}}$ \\
\hline 2 & $5623^{\text {abcde }}$ & $27.8^{\mathrm{c}}$ & 0.39 & $6.75^{\mathrm{bc}}$ & $73.2^{\mathrm{c}}$ & $0.60^{\text {abcd }}$ \\
\hline 3 & $3327^{\mathrm{e}}$ & $16.0^{\mathrm{d}}$ & 0.40 & $4.00^{\mathrm{d}}$ & $30.5^{\mathrm{d}}$ & $0.71^{\mathrm{ab}}$ \\
\hline 4 & $5458^{\text {bcde }}$ & $27.1^{\mathrm{c}}$ & 0.39 & $6.54^{\mathrm{bc}}$ & $82.2^{\mathrm{c}}$ & $0.48^{\text {defg }}$ \\
\hline 5 & $5067^{\text {cde }}$ & $31.5^{\mathrm{bc}}$ & 0.36 & $7.17^{\mathrm{bc}}$ & $100.2^{c}$ & $0.43^{\text {efgh }}$ \\
\hline 6 & $8131^{\mathrm{a}}$ & $40.9^{\mathrm{a}}$ & 0.41 & $10.54^{\mathrm{a}}$ & $200.7^{\mathrm{a}}$ & $0.34^{\mathrm{gh}}$ \\
\hline 7 & $7697^{\mathrm{ab}}$ & $36.1^{\mathrm{ab}}$ & 0.34 & $7.93^{b}$ & $111.4^{\mathrm{c}}$ & $0.43^{\text {efgh }}$ \\
\hline 8 & $6190^{\mathrm{abc}}$ & $42.5^{\mathrm{a}}$ & 0.39 & $10.24^{\mathrm{a}}$ & $198.0^{\mathrm{ab}}$ & $0.31^{\mathrm{h}}$ \\
\hline 9 & $5869^{\mathrm{abcd}}$ & $27.5^{\mathrm{c}}$ & 0.39 & $6.78^{\mathrm{bc}}$ & $104.2^{\mathrm{c}}$ & $0.46^{\text {defgh }}$ \\
\hline 10 & $3166^{\mathrm{e}}$ & $14.5^{\mathrm{d}}$ & 0.39 & $3.53^{\mathrm{d}}$ & $23.0^{\mathrm{d}}$ & $0.57^{\text {bcde }}$ \\
\hline 11 & $6935^{\mathrm{abc}}$ & $44.0^{\mathrm{a}}$ & 0.39 & $10.29^{\mathrm{a}}$ & $158.3^{\mathrm{b}}$ & $0.34^{\mathrm{gh}}$ \\
\hline 12 & $6749^{\mathrm{abc}}$ & $30.4^{\mathrm{bc}}$ & 0.37 & $7.12^{\mathrm{bc}}$ & $86.5^{\mathrm{c}}$ & $0.50^{\mathrm{def}}$ \\
\hline 13 & $5612^{\text {bcde }}$ & $25.5^{\mathrm{c}}$ & 0.38 & $6.16^{\mathrm{c}}$ & $92.0^{\mathrm{c}}$ & $0.47^{\mathrm{defg}}$ \\
\hline 14 & $3174^{\mathrm{e}}$ & $12.7^{\mathrm{d}}$ & 0.44 & $3.51^{\mathrm{d}}$ & $25.2^{\mathrm{d}}$ & $0.74^{\mathrm{a}}$ \\
\hline 15 & $6107^{\mathrm{abc}}$ & $43.2^{\mathrm{a}}$ & 0.36 & $9.81^{\mathrm{a}}$ & $178.5^{\mathrm{ab}}$ & $0.37^{\text {fgh }}$ \\
\hline 16 & $4699^{\text {cde }}$ & $25.3^{\mathrm{c}}$ & 0.39 & $6.19^{\mathrm{c}}$ & $80.1^{\mathrm{c}}$ & $0.50^{\text {defg }}$ \\
\hline 17 & $4825^{\text {cde }}$ & $25.0^{\mathrm{c}}$ & 0.40 & $6.27^{\mathrm{c}}$ & $81.8^{\mathrm{c}}$ & $0.52^{\text {def }}$ \\
\hline 18 & $6457^{\mathrm{abc}}$ & $28.2^{\mathrm{bc}}$ & 0.37 & $6.58^{\mathrm{bc}}$ & $79.2^{\mathrm{c}}$ & $0.53^{\text {cde }}$ \\
\hline 19 & $4449^{\text {cde }}$ & $24.2^{\mathrm{c}}$ & 0.38 & $5.80^{\mathrm{c}}$ & $92.4^{\mathrm{c}}$ & $0.49^{\text {defg }}$ \\
\hline
\end{tabular}

Analysis of variance indicated that the thixotropy, consistency and viscosity of samples varied significantly depending on the composition while pseudoplasticity did not vary significantly (Table 5). For each flow parameter, its relationship with composition was determined by fitting data to a second-order equation. According to the resulting models (Table 6), the differences in flow parameters can be explained by both concentration of sucrose and inulin. The thixotropic area increased linearly with sucrose and inulin concentrations (Fig. 2a), whereas the consistency index and apparent viscosity at $10 \mathrm{~s}^{-1}$ increased in a quadratic way with both ingredients. For the consistency index these effects can be observed in Fig. 2b and a similar trend was observed for apparent viscosity at $10 \mathrm{~s}^{-1}$. 
Table 5. Analysis of variance of one factor (sample) of rheological parameters. F and $\mathrm{p}$ values. Degree of freedom $=18$.

\begin{tabular}{ccccccc}
\hline & \multicolumn{3}{c}{ Flow } & & \multicolumn{2}{c}{ Viscoelasticity } \\
\cline { 2 - 7 } & Thixotropic area & $\mathrm{k}$ & $\mathrm{n}$ & $\eta_{10}$ & $\mathrm{G}^{\prime}$ & $\tan \delta$ \\
\hline $\mathrm{F}$ & 3.0 & 12.9 & 1.3 & 18.4 & 15.9 & 5.4 \\
$p$ & 0.011 & $<0.001$ & 0.267 & $<0.001$ & $<0.001$ & $<0.001$ \\
\hline
\end{tabular}

Table 6. Regression models relating rheological parameters with inulin (I), sucrose (S) and lemon flavor (L) concentrations.

\begin{tabular}{ll}
\hline Model & $\mathrm{R}^{2}$ \\
\hline Thixotropic area $=233.62 \mathrm{~S}+520.19 \mathrm{I}$ & 0.95 \\
$\mathrm{k}=0.624+0.103 \mathrm{~S}^{2}+0.435 \mathrm{I}^{2}$ & 0.87 \\
$\eta$ at $10 \mathrm{~s}^{-1}=0.429+0.026 \mathrm{~S}^{2}+0.095 \mathrm{I}^{2}$ & 0.90 \\
$\mathrm{G}^{\prime}$ at $1 \mathrm{~Hz}=-50.30+0.89 \mathrm{I}^{2}+1.88 \mathrm{SI}$ & 0.90 \\
$\tan \delta$ at $1 \mathrm{~Hz}=1.125-0.020 \mathrm{~S}-0.071 \mathrm{I}$ & 0.76 \\
\hline
\end{tabular}

To study viscoelastic properties, mechanical spectra were obtained for each of the studied samples. All of them showed the typical behavior of weak gels with G' values above those of G', both of which were quite frequency-dependent (Fig. 3.). The values of $\mathrm{G}^{\prime}$ and $\tan \delta$ were taken at $1 \mathrm{~Hz}$ (Table 4) and for both parameters ANOVA indicated significant differences among samples (Table 5). According to the model given by the multiple regression analysis (Table 6), G' values mainly depended on inulin concentration but also on its interaction with sucrose concentration. Thus, sample elasticity increased in line with inulin concentration in a quadratic way and the higher the sucrose concentration in the sample, the greater the increase. For $\tan \delta$, values decreased linearly with the sucrose and inulin concentrations. A contour plot of viscoelastic properties is given in Fig. 4. 

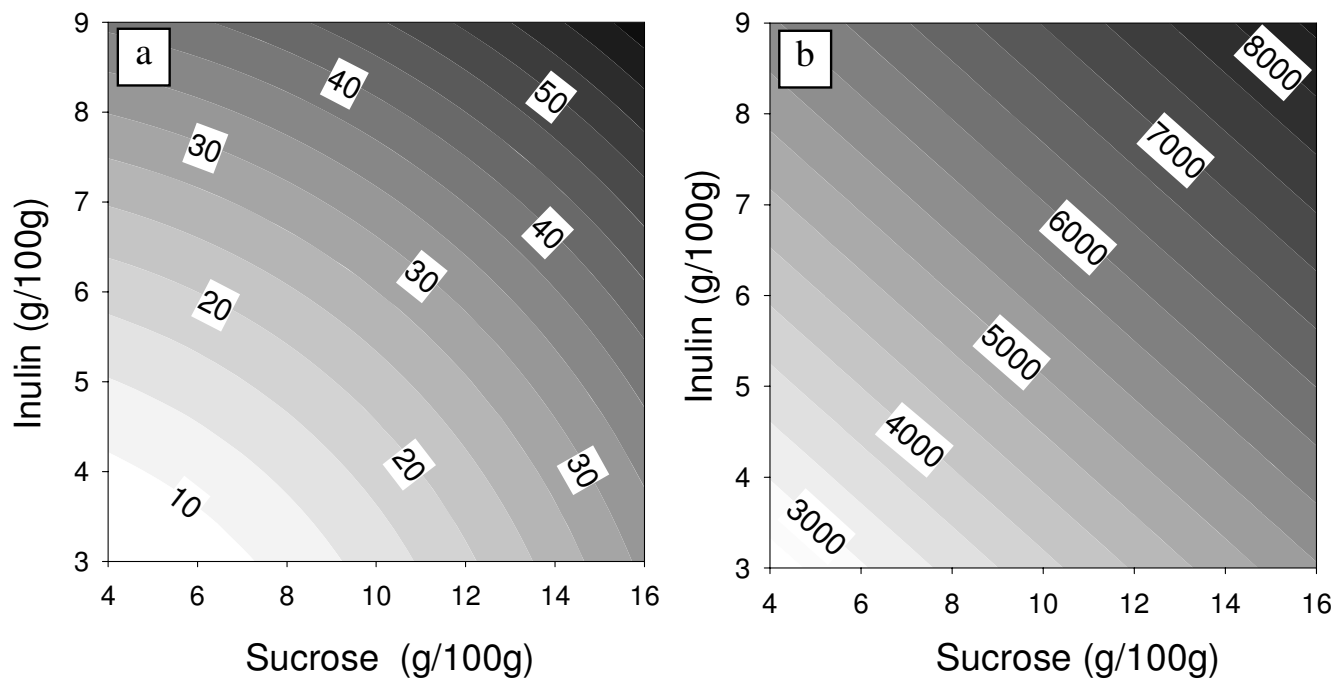

Figure 2. Contour plot of the model relating: a) thixotropic area in $\mathrm{Pa}_{\mathrm{s}} \mathrm{s}^{-1}$, and b) consistency index in Pa.s $\mathrm{s}^{\mathrm{n}}$ with inulin concentration and sucrose concentration.

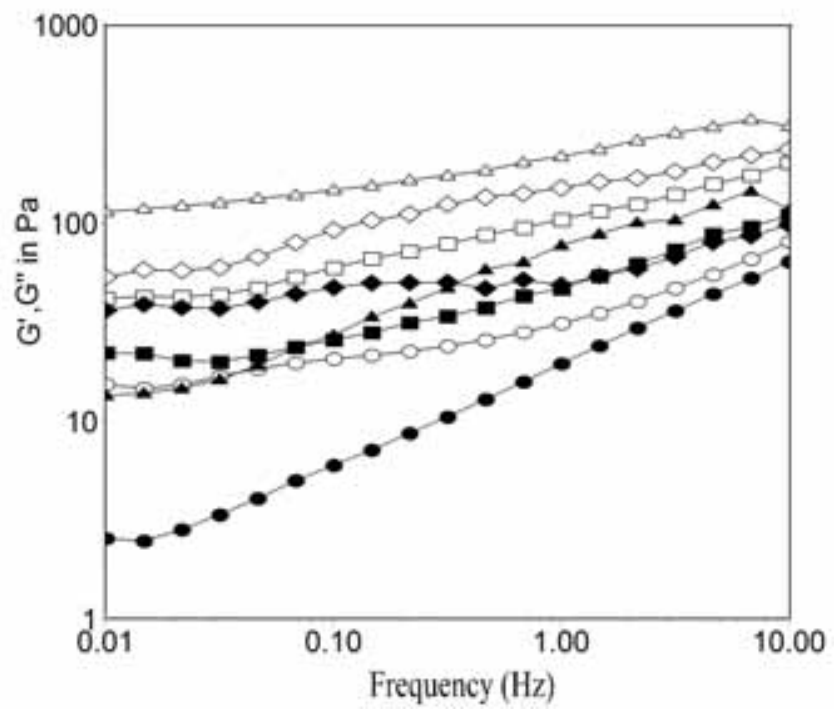

Figure 3. Mechanical spectra of samples: $1(\bullet), 9(\boldsymbol{\square}), 11(\mathbf{\Delta})$ and $15(\bullet)$. Values of G' (filled symbols) and G', (open symbols). Identification of samples in Table 1. 

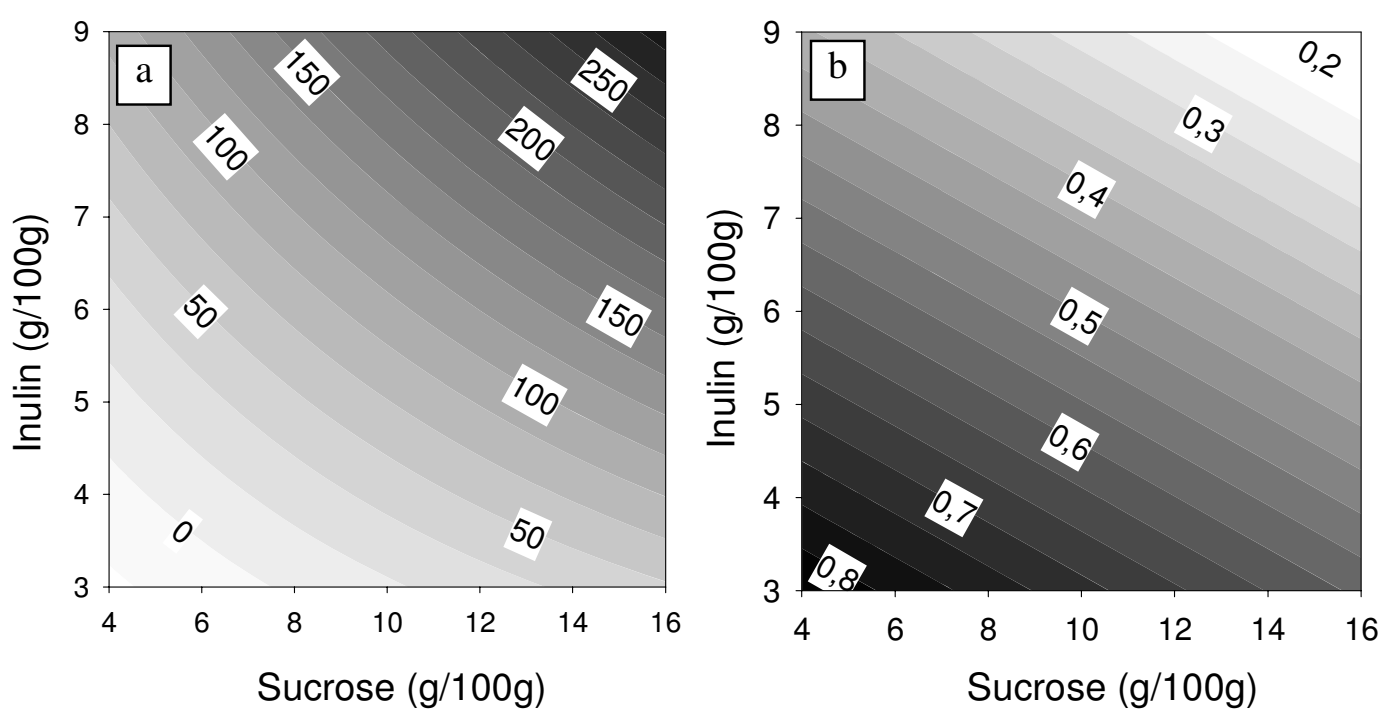

Figure 4. Contour plot of the model relating: a) elastic modulus in $\mathrm{Pa}$, and b) tan $\delta$ with inulin concentration and sucrose concentration.

According to rheological results, the addition of mixed short and long chain inulin was able to modify the rheological properties of dairy dessert. The effect depended not only on the inulin concentration but also on the sucrose concentration, thus giving a wide range of products with different rheological behaviour. While differences in consistency were attributed to sucrose concentration and inulin concentration, the differences in elasticity were mainly due to inulin concentration and its interaction with sucrose. This can be explained by the different way in which the two ingredients modify the continuous phase of the system. Sucrose became a solute in the continuous phase, binding water molecules, thus increasing the viscosity of the continuous phase of the system. In the case of inulin, the shortchain molecules would also remain solubilised in the continuous phase and cause the same effect as sucrose. However, long-chain inulin has the ability to crystallize and form aggregates (Torres, Tárrega, \& Costell, 2010); therefore, by this 
mechanism, apart from occluding water, it creates a new structure within the continuous phase which is responsible for increasing the elastic response of the system. As indicated by the interaction effect, sucrose contributed to elasticity indirectly. The effect of inulin on elasticity was higher for high-sucrose samples due to the water retention ability of sucrose, which increased the inulin effective concentration. Finally, with regard to lemon flavour, although changes in rheological properties due to food flavour components have been reported in some cases (Lubbers \& Decourcelle, 2004), in our study the concentration of lemon flavor did not affect any of the rheological parameters studied.

\section{Thickness suitability assessed by consumers. Effect of composition}

The JAR scale was used to evaluate thickness appropriateness of a low-fat dessert to determine how much each sample varied or approached the desirable level for this product. The percentage of consumers that considered thickness to be just about right varied greatly among samples, from 19\% for sample 6 to $70 \%$ for sample 9 (central point of the design) (Table 7). The model explaining the relationship between the percentage of consumers considering thickness as JAR (\% Consumer in JAR 3) and sample composition (S: Sucrose; I: Inulin) is as follows:

$$
\begin{gathered}
\% \text { Consumers in JAR } 3=-407.60+82.66 \mathrm{I}+47.99 \mathrm{~S}-3.83 \mathrm{I}^{2}-1.26 \mathrm{~S}^{2}-3.94 \mathrm{SI} \\
\mathrm{R}^{2}=0.94
\end{gathered}
$$

Both sucrose and inulin concentration significantly affected thickness appropriateness, showing an inverted U-shape relationship within the concentration ranges considered in this study (Fig. 5.a). The most adequate thickness corresponded to samples with intermediate levels of inulin and sucrose. 
Table 7. Percentage of consumers considering thickness as JAR and positive and negative deviation values for each dairy dessert sample. Identification of samples in Table 1.

\begin{tabular}{|c|c|c|c|}
\hline \multirow[b]{2}{*}{ Sample } & \multirow{2}{*}{$\begin{array}{l}\text { Consumers considering } \\
\text { thickness as JAR }(\%)\end{array}$} & \multicolumn{2}{|c|}{ Deviation } \\
\hline & & Too little & $\begin{array}{l}\text { Too } \\
\text { Much }\end{array}$ \\
\hline 1 & 38 & -0.72 & 0.03 \\
\hline 2 & 65 & -0.11 & 0.26 \\
\hline 3 & 30 & -0.83 & 0.01 \\
\hline 4 & 65 & -0.25 & 0.12 \\
\hline 5 & 59 & -0.04 & 0.45 \\
\hline 6 & 19 & 0.00 & 1.22 \\
\hline 7 & 65 & -0.06 & 0.40 \\
\hline 8 & 25 & 0.00 & 1.08 \\
\hline 9 & 69 & -0.15 & 0.20 \\
\hline 10 & 30 & -0.88 & 0.03 \\
\hline 11 & 20 & -0.02 & 1.15 \\
\hline 12 & 69 & -0.19 & 0.13 \\
\hline 13 & 69 & -0.18 & 0.16 \\
\hline 14 & 45 & -0.60 & 0.04 \\
\hline 15 & 27 & -0.01 & 0.93 \\
\hline 16 & 65 & -0.13 & 0.22 \\
\hline 17 & 65 & -0.09 & 0.28 \\
\hline 18 & 78 & -0.02 & 0.21 \\
\hline 19 & 72 & -0.24 & 0.06 \\
\hline
\end{tabular}

* samples 16 to 19 are replication of the central point (sample 9). 

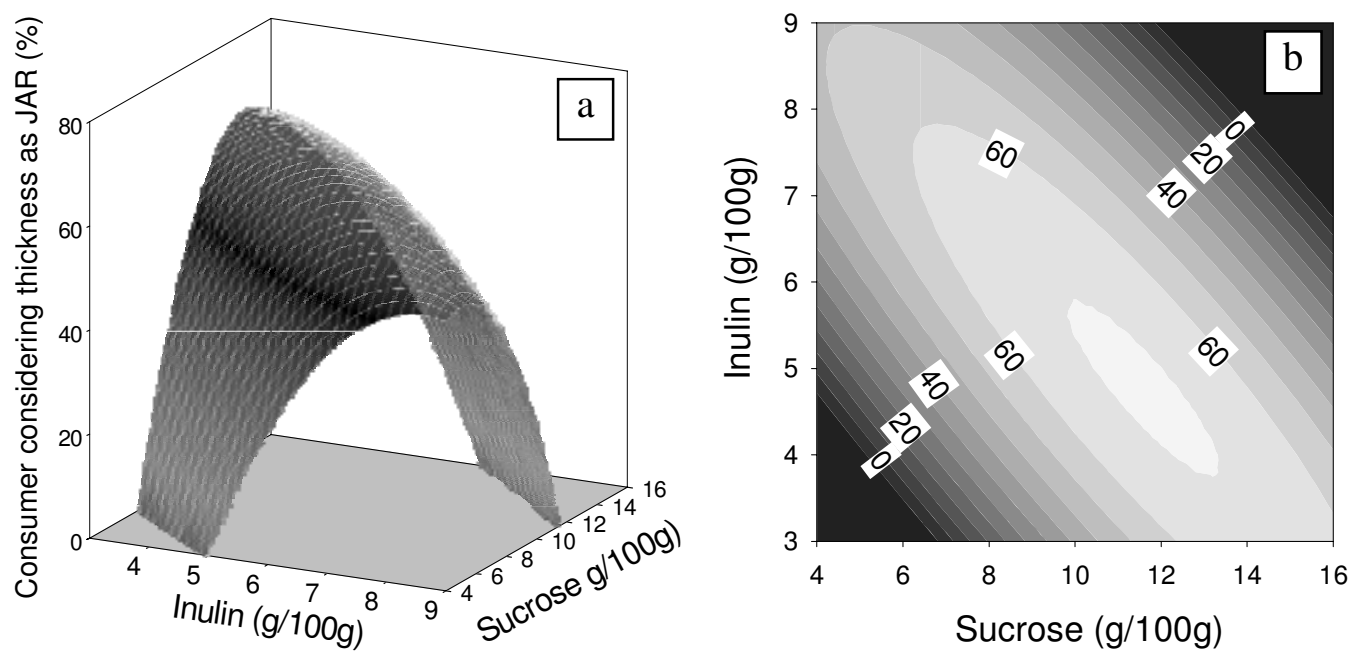

Figure 5. Relation between percentage of consumers considering thickness of samples as JAR and sucrose concentration and inulin concentration. Response surface (a) and contour plot (b).

Due to the interaction effect, the combination of low sucrose-high inulin and vice versa also led to samples with adequate thickness (Fig. 5. b).

For consumers who did not consider thickness as adequate but considered it as "too much" or "too little", thickness deviation from the JAR was calculated for each sample (Table 7). Deviation values depended on both inulin and sucrose content. The effect of inulin depended on sucrose concentration and vice-versa. On one hand the addition of inulin at low concentrations $(\leq 4.5 \%)$ resulted in samples with too weak thickness but only when sucrose content was $\leq 10 \%$ (samples 1,3 , and 14). On the other hand, inulin addition at high concentration $(\geq 7.5 \%)$ resulted in samples whose thickness was considered excessive. The effect was slight for samples with low sucrose level (5 and 7) and strong for high sucrose levels (6,8 and 15). 
Regarding the effect of sucrose, samples with low levels $(\leq 7 \%)$ were not thick enough if inulin concentration was $\leq 6 \%$ (samples 1,3 and 10) and too much thick samples were obtained with high sucrose levels $(\geq 13 \%)$ if inulin concentration was $\geq 6 \%$ (samples 6,8 and 11 ).

\section{Relationship between rheological properties and thickness suitability}

Both rheological parameters and thickness adequacy assessed by consumers have been shown to vary with desserts composition. From a practical viewpoint, it could be interesting to know how the desirable thickness level can be associated with the values of certain rheological parameters. To do so, two different graphical approaches were used. The first one based on the percentage of consumers that considered thickness as JAR and the second one based on the JAR deviations. All rheological parameters were studied and only those showing a relation with the thickness intensity assessed by consumers are discussed below. Given the flow parameters, both consistency index and apparent viscosity at $10 \mathrm{~s}^{-1}$ showed to be related with thickness adequacy. The relationship between the consistency index and the consumer percentage that considered thickness as JAR is shown in Fig. 6.a. and a similar plot was obtained for apparent viscosity at $10 \mathrm{~s}^{-1}$. According to them, samples with $\mathrm{K}$ values in the range of 25-37 $\mathrm{Pa} \cdot \mathrm{s}^{\mathrm{n}}$ or with $\eta_{10}$ values in the range of 5.8-7.9 Pa.s were those with the most desirable thickness (considered by over $60 \%$ consumers as JAR). Thickness of samples with K values below $16 \mathrm{~Pa} . \mathrm{s}^{\mathrm{n}}$ and above $40 \mathrm{~Pa} . \mathrm{s}^{\mathrm{n}} \quad\left(\eta_{10}\right.$ values below $4.0 \mathrm{~Pa} . \mathrm{s}$ and above 9.8 Pa.s) was considered inadequate by over $55 \%$ and $70 \%$ of consumers, respectively. In the second approach the relationship between the consistency index and the "too little" and "too much" deviation of JAR thickness was studied (Fig. 6.b). In this study, a relevant deviation was considered to exist only when the value was above 0.25 and below -0.25 for "too much" and "too little", 
respectively (dotted line). According to this criterion, samples with $\mathrm{K}$ values between 25 and $31 \mathrm{~Pa} . \mathrm{s}^{\mathrm{n}}$ or $\eta_{10}$ between 5.8 and 7.1 with did not deviate from ideal thickness. As can be observed, the obtained range of $\mathrm{k}$ and $\eta_{10}$ values could differ depending on the approach. Values of $\mathrm{K}$ from 31 to $37 \mathrm{~Pa} . \mathrm{s}^{\mathrm{n}}$ and values of $\eta_{10}$ from 7.1 to 7.9 Pa.s, which according to the first approach corresponded to adequate thickness, were not included in the second approach because for these cases, although over $60 \%$ of consumers considered thickness as JAR, the rest of consumers coincided in considering the samples as too thick.

A similar procedure was followed to assess viscoelastic parameters, with the storage modulus proving to be the most closely related with thickness adequacy. According to Fig. 7.a, samples with G' values in the range of 73-112 Pa were those with the most desirable thickness. Thickness of samples with $G$ ' values below $31 \mathrm{~Pa}$ and above $150 \mathrm{~Pa}$ were considered inadequate. The relationship between G' and both "too little" and "too much" deviation of JAR thickness is shown in Fig. 7.b As observed in the consistency index, the ranges of G' values were narrower for this second approach. In this case, samples without relevant deviation from JAR thickness were those with $\mathrm{G}^{\prime}$ values between 73 and $100 \mathrm{~Pa}$. Both flow and viscoelastic measurements provided instrumental indexes of the adequacy of semisolid desserts thickness. Flow curve parameters (consistency and viscosity) are obtained under large deformation values and elastic modulus is obtained at small deformation ones. They reflect different phenomena and can give different and complementary information. In this work variation of consistency and viscosity values among samples did not follow exactly the same pattern than values of the elastic modulus (Table 4). However both types of parameters showed the same relation with thickness adequacy. This indicates that the slight differences among parameters are not implicated in how much adequate thickness was perceived by consumers. From a practical viewpoint, 
each of selected rheological parameters $\left(\mathrm{K}, \eta_{10}\right.$, and $\mathrm{G}^{\prime}$ at $\left.1 \mathrm{~Hz}\right)$ can be used as instrumental index of thickness suitability in this type of products.
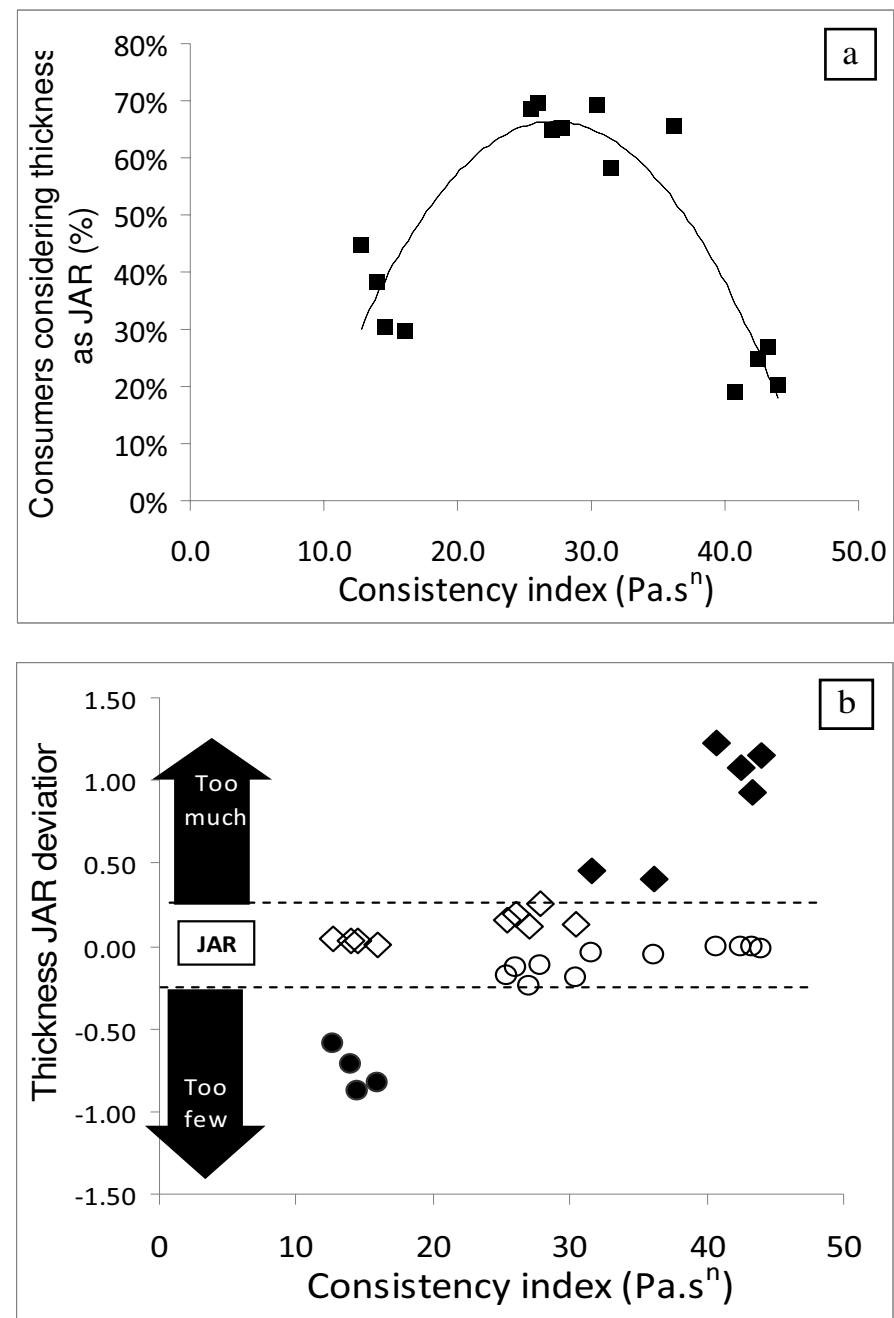

Figure 6. Consistency index related to the percentage of consumers considering thickness as JAR (a) and to JAR thickness deviation (b). Values of too much deviation (diamond) and too little deviation (circle) considered as relevant $(>0.25,--)$ have filled symbol. 

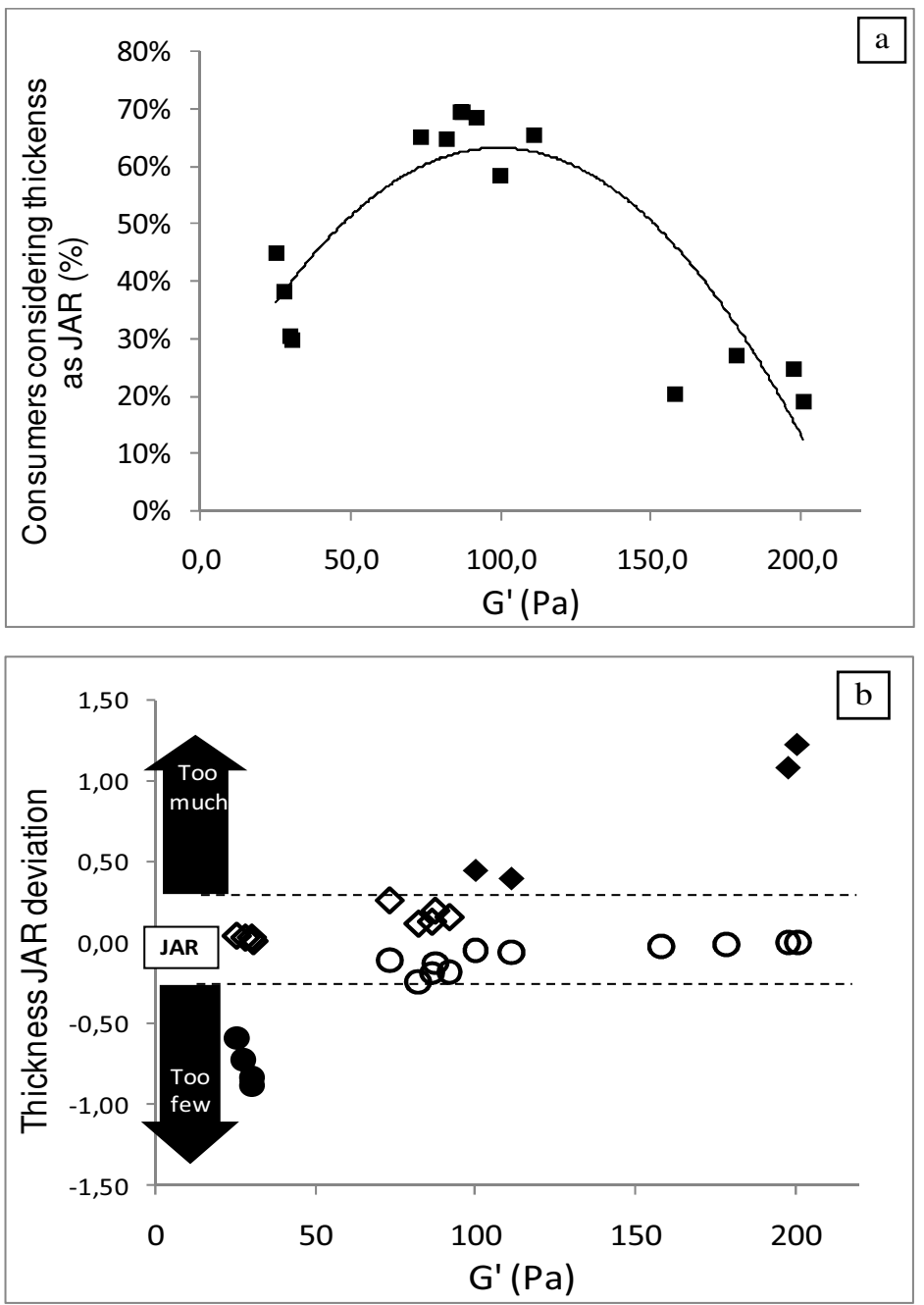

Fig. 7. Storage modulus related to the percentage of consumers considering thickness as JAR (a) and to JAR thickness deviation (b). Values of too much deviation (diamond) and too little deviation (circle) considered as relevant ( $>0.25,---)$ have filled symbol. 


\section{CONCLUSIONS}

Flow and viscoelastic properties of dairy desserts enriched with a mixture of short and long-chain inulin vary greatly with composition. By varying both inulin and sucrose concentrations a wide range of products with different rheological properties can be obtained. These differences in the dairy desserts are also perceived by consumers as differences in thickness adequacy. An inulin-enriched dessert with the most ideal thickness can be achieved through formulations containing inulin in the range from 3.5 to $6 \%$ and adjusting the sucrose amount. For this type of product, the most desirable thickness level corresponds to consistency index values between 25-31 Pa.s $\mathrm{s}^{\mathrm{n}}$, apparent viscosity values at $10 \mathrm{~s}^{-1}$ between 5.8-7.1 Pa.s and G' values between 73-100 Pa.

JAR methodology is a useful tool to assess attribute adequacy. As shown in this work, data thus obtained can be related with instrumental measurements to determine which parameters and ranges can be taken as indicators of the desirable level for each attribute. From a practical point of view, this information could be useful in product reformulation to preliminarily evaluate sample adequacy by means of instrumental measurements, instead of the more timeconsuming and expensive consumer tests.

\section{ACKNOWLEDGMENTS}

To MICINN of Spain for financial support (AGL 2007-63444). To Fondo Social Europeo for financing author Tarrega (JAE programme, CSIC). To Laboratorio Tecnológico del Uruguay for financing the stage training of author Arcia. To CHR Hansen S.A., Lucta S.A., Brenntag Quimica and Central Lechera Asturiana for providing free samples of the ingredients 


\section{REFERENCES}

Acquarone, V. M., \& Rao, M. A. (2003). Influence of sucrose on the rheology and granule size of cross-linked waxy maize starch dispersions heated at two temperatures. Carbohydrate Polymers, 51, 451-458.

Bayarri, S., Chuliá, I., \& Costell, E (2010). Comparing lambda-carrageenan and an inulin blend as fat replacers in carboxymethyl cellulose dairy desserts. Rheological and sensory aspects, Food Hydrocolloids, 24, 578,587.

Biedrzycka, E., \& Bielecka, M. (2004). Prebiotic effectiveness of fructans of different degrees of polymerization. Trends in Food Science \& Technology, 15, 170-175.

Bult, J.H.F., De Wijk, R.A., \& Hummel, T. (2007) Investigations on multimodal sensory integration: Texture, taste, ortho- and retronasal stimuli in concert. Neuroscience Letters 411, 6 - 10

Cayot, N., Lafarge, C., Arvisenet, G., \& Taisant, C. (2000). Influence of aroma compounds on the mechanical properties of starch-based food systems. Journal of Texture Studies 31, 297-313.

Chiavaro, E., Vittadini, E., \& Corradini, C. (2007) Physicochemical characterization and stability of inulin gels. European Food Research and Technology 225, 85-94.

Costell, E., Tárrega, A., \& Bayarri, S. (2010). Food Acceptance: The Role of Consumer Perception and Attitudes. Chemosensory Perception, 3, 42-52.

Coudray, C., Tressol, J. C., Gueux, E., \& Rayssiguier, Y. (2003). Effects of inulin-type fructans of different chain length and type of branching on intestinal absorption and balance of calcium and magnesium in rats. European Journal of Nutrition, 42, 91-98. 
Deliza, R., MacFie, H., \& Hedderley, D. (2005). The consumer sensory perception of passion-fruit juice using free-choice profiling. Journal Sensory Study, 20, 17-27.

de Wijk, R. A., van Gemert, L. J., Terpstra, M. E. J., \& Wilkinson, C. L. (2003). Texture of semi-solids; sensory and instrumental measurements on vanilla custard desserts, Food Quality and Preference, 14 (4), 305-317.

Dickinson, E. (2007). Food colloids... How do interactions of ingredients control structure, stability and rheology? Current Opinion in Colloid \& Interface Science, 12, 155-157.

Doublier, J. L., \& Durand, S. (2008). A rheological characterization of semi-solid dairy systems. Food Chemistry 108, 1169-1175.

Gacula, M. (1993). Design and analysis of sensory optimization. Trumbull: Food and Nutrition Press.

Gacula, M., Rutenbeck, S., Pollack, L., Resurreccion, A., \& Moskowitz, H. (2007). The just-about-right intensity scale: functional analyses and relation to hedonic. Journal of Sensory Studies, 22, 194-211.

González-Tomás, L., Costell, E. (2006) Sensory evaluation of vanilla-dairy desserts by repertory grid method and free choice profile. Journal of Sensory Studies, 21 (1), 20-33.

González-Tomás, L., Bayarri, S., Coll-Marqués. J., \& Costell, E. (2009). Flow behaviour of inulin-enriched dairy desserts: influence of inulin average chain length. International Journal of Food Science and Technology, 44, 1214-1222.

Hasler, C. M. (1998). Functional foods: their role in disease prevention and health promotion. Food Technology, 52 (11), 63-70.

Hébette, C.L.M., Delcour, J.A., Koch, M.H.J., Booten, K., Kleppinger, R., \& Mischenkod, N. (1998). Complex melting of semi-crystalline chicory (Cichorium intybus L.) root inulin, Carbohydrate Research, 310, 65-75. 
Hill, M. A., Mitchell, J. R., \& Sherman, P. A. (1995). The relationship between the rheological and sensory properties of a lemon pie filling. Journal of Texture Studies 26, 457-470.

ISO (2007). General guidance for the design of test room. Standard No 8589:2007. International Organization for Standardization, Geneva, Switzerland.

Kohyama, K., \& Nishinari, K. (1991). Effect of soluble sugars on gelatinization and retrogradation of sweet potato starch. Journal of Agricultural and Food Chemistry 39, 1406-1410.

Kruger, A., Ferrero, C., \& Zaritzky, N. E. (2003). Modelling corn starch swelling in batch systems: effect of sucrose and hydrocolloids. Journal of Food Engineering, 58, 125-133.

Liu, H., Eskin, N. A. M., \& Cui, S. W. (2003). Interactions of wheat and rice starches with yellow mustard mucilage. Food Hydrocolloids, 17, 863-869.

Lubbers, S., \& Decourcelle, N. (2004). Influence of Aroma Compounds on the Mechanical Properties of Pectin Gels. Journal of Agricultural and Food Chemistry. 52 (5), 3077-3082.

MacFie, H. J., Bratchell, N., Greenhoff, K., \& Vallis, L. V. (1989). Designs to balance the effect of order of presentation and first-order carry over effects in Hall Tests. Journal of Sensory Studies, 4, 129-148.

Matser, A. M., \& Steeneken, P. A. M. (1997). Rheological properties of highly cross-linked waxy maize starch in aqueous suspensions of skim milk components. Effects of the concentration of starch and skim milk components. Carbohydrate Polymers, 32, 297-305.

Milner, J. A. (1999). Functional Foods and Health Promotion. The Journal of Nutrition, 129 (7), 1395-1397. 
Nguyen, Q. D., Jensen, C. T. B., \& Kristensen P. G. (1998). Experimental and modelling studies of the flow properties of maize and waxy maize starch pastes. Chemical Engineering Journal, 70. 165-171.

Paseephol, T., Small, D. M., \& Sherkat, F. (2008). Rheology and texture of set yogurt as affected by inulin addition. Journal of Texture Studies, 39 (6), 617-634.

Purwanti, N., van der Goot, A. J., Boom, R., \& Vereijken, J. (2010). New directions towards structure formation and stability of protein-rich foods from globular proteins. Trends in Food Science \& Technology, 21, 85-94.

Richardson, R. K., Morris, E. R., Ross-Murphy, S. B., Taylor, L. J., \& Dea, I. C. M. (1989). Characterization of the perceived texture of thickened systems by dynamic viscosity measurements. Food Hydrocolloids, 3, 175-191.

Roberfroid M. B. (2007). Inulin-type fructans: functional food ingredients. Journal of Nutrition, 137, 2493-2502.

Sikora, M., Mazurkiewicz, J., Tomasik, P., \& Pielichowski, K., (1999). Rheological properties of some starch-water-sugar systems. International Journal of Food Science and Technology, 34, 371-383.

Soukoulis, C., Lebesi, D., \& Tzia, C. (2009). Enrichment of ice cream with dietary fibre: effects on rheological properties, ice crystallisation and glass transition phenomena. Food Chemistry, 115 (2), 665-671.

Tárrega, A., \& Costell, E. (2006). Effect of inulin addition on rheological and sensory properties of fat-free starch-based dairy desserts. International Dairy Journal. 16, 1104-1112.

Tárrega, A., \& Costell, E. (2007). Colour and consistency of semi-solid dairy desserts: Instrumental and sensory measurements. Journal of Food Engineering, 78 (2), 655-661. 
Tárrega, A., Rocafull, A., \& Costell, E. (2010). Effect of blends of short and long-chain inulin on the rheological and sensory properties of prebiotic low-fat custards. LWT - Food Science and Technology, 43 (3), 556-562.

Tecante, A., \& Doublier, J. L. (1999). Steady flow and viscoelastic behavior of crosslinked waxy cornstarch-k-carrageenan pastes and gels. Carbohydrate Polymers, 40, 221-231.

Thebaudin, J. Y., Lefebvre, A. C., \& Doublier, J. L. (1998). Rheology of starch pastes from starches of different origins: Aplications to starch-based sauces. Lebensmitttel Wissenschaft und Thecnologie, 31, 354-360.

Torres, J. D., Tárrega, A., \& Costell, E. (2010). Storage stability of starch-based dairy desserts containing long-chain inulin: Rheology and particle size distribution. International Dairy Journal, 20 (1), 46-52.

Van Vliet, T. (2002). On the relation between texture perception and fundamental mechanical parameters for liquids and time dependent solids, Food Quality and Preference, 13, 227-236. 


\title{
CAPÍTULO 6
}

\author{
Inulin blend as prebiotic and fat \\ replacer in dairy desserts: optimization \\ by Response Surface Methodology
}

Journal of Dairy Science, 94 (2011), 2192-2200 



\title{
INULIN BLEND AS PREBIOTIC AND FAT REPLACER IN DAIRY DESSERTS: OPTIMIZATION BY RESPONSE SURFACE METHODOLOGY
}

\author{
P. L. Arcia * $\dagger$, E. Costell *, A. Tárrega * \\ * Instituto de Agroquímica y Tecnología de Alimentos, CSIC, Valencia, España. \\ $\dagger$ Laboratorio Tecnológico del Uruguay, Montevideo, Uruguay.
}

\begin{abstract}
The purpose of this work was to optimize the formulation of a prebiotic dairy dessert with low fat content $(<0.1 \mathrm{~g} / 100 \mathrm{~g})$ using a mixture of short- and longchain inulin. Response Surface Method (RSM) was applied to obtain the experimental design and data analysis. Nineteen formulations of dairy dessert were prepared, varying inulin concentration (3 to $9 \mathrm{~g} / 100 \mathrm{~g}$ ), sucrose concentration (4 to $16 \mathrm{~g} / 100 \mathrm{~g}$ ) and lemon flavor concentrations (25 to 225 $\mathrm{mg} / \mathrm{kg}$ ). Sample acceptability, evaluated by a total of 100 consumers, varied mainly in terms of inulin and sucrose concentrations and, to a lower extent, of lemon flavor content. An interaction effect among inulin and sucrose concentration was also found $(\mathrm{p}=0.05)$. According to the model obtained, the formulation with $5.5 \mathrm{~g} / 100 \mathrm{~g}$ inulin, $10 \mathrm{~g} / 100 \mathrm{~g}$ sucrose and $60 \mathrm{mg} / \mathrm{kg}$ of lemon flavor was selected. Finally, this sample was compared sensorially with the regular fat content $(2.8 \mathrm{~g} / 100 \mathrm{~g})$ sample previously optimized in terms of lemon flavor $(146 \mathrm{mg} / \mathrm{kg})$ and sucrose $(11.4 \mathrm{~g} / 100 \mathrm{~g})$. There was no significant difference in acceptability between them but the low-fat sample with inulin possessed stronger lemon flavor, greater thickness and creaminess.
\end{abstract}

Key words: optimization, response surface method, dairy desserts, inulin. 


\section{INTRODUCTION}

Inulin is a mixtue of oligo - and polysaccharides, which are composed of fructose units connected by $\beta-(2-1)$ links. This ingredient is of interest for the development of healthy products because it simultaneously responds to a variety of consumer demands: fiber-enriched, prebiotic, low-fat and low-sugar. As a dietary fiber, inulin passes through the digestive tract largely undigested, and in the colon acts as prebiotic because it is selectively fermented by the beneficial flora, stimulates their growth, and reinforces its action against putrefactive microorganisms (Roberfroid et al. 1998). Inulin products containing mainly longchain molecules are used for fat replacement because in the presence of water they are able to form a particulate gel, thus modifying the product texture and giving rise to a fat-like mouthfeel (Tungland and Meyer, 2002; Franck, 2002). Inulin products containing mainly short-chain molecules enhance flavor and sweetness and are used to partially replace sucrose (Franck, 2002; De Castro et al., 2009; Villegas et al., 2010). Several nutritional studies (Coudray et al., 2003; Biedrzycka and Bielecka, 2004) recommend the use of blends of short- and longchain inulin in order to maximize fermentative and prebiotic effects, because they are selectively metabolized in different portions of the large intestine (shortchain in the proximal colon and long-chain in more distal colonic regions). The blend of short- and long-chain inulin at the ratio 50:50 affords some extra advantages, improving prebiotic effectiveness. It enhances calcium absorption and bone mineralization in pubertal adolescents (Abrams et al., 2005) and proves effective in reducing the amount of gas produced while increasing or maintaining its prebiotic effect (Ghoddusi et al., 2007).

Certain authors have analyzed the effect of inulin addition on physical and sensorial characteristics of semisolid dairy products such as yogurt or custard. Long chain inulin has been used in low-fat yogurts as fat replacer where it was 
shown to significantly improve the creaminess, mouthfeel and smoothness (Kip et al., 2006, Modzelewska-Kapitula and Klebukowska, 2009). In custard desserts, the addition of short-chain inulin enhanced flavour and sweetness although it did not significantly changed the texture (González-Tomás et al., 2009). Meanwhile, the addition of long-chain inulin improved creaminess and consistency of low-fat custards (Lobato et al., 2009) and mimicked those of fullfat custard (Tarrega and Costell, 2006). According to that, the inulin blends are expected to modify sensory properties, especially sweetness, flavor and texture, as reflected by the combined effects of the two inulin types. The magnitude of the sensory changes depends on the blend ratio (Cardarelli et al., 2008; Tárrega et al., 2010) and on the total inulin concentration (Bayarri et al., 2010). However, prior knowledge of these sensory changes is not enough to predict acceptance of a given product formulation because it will depend on the extent to which the variation of these sensory characteristics influence consumer response, and also whether it is affected by other ingredients in the formulation.

Response Surface Methodology (RSM) is a useful tool for optimising sensory quality of foods. Following appropriate statistical designs, the experimental data relate the variation in consumer's responses to variations in previously selected factors (Damasio et al., 1999; Gacula, 1993). An optimal formulation maximizes consumer acceptance in that it is the best possible formulation given a fixed set of ingredients (Acosta et al., 2008, Damasio et al., 1999; Gan et al., 2006). RSM was successfully used to identify the best combination of ingredients in new developed products with health-promoting characteristics such as soy baseddesserts (Granato et al., 2010; Granato, et al.,2010), prebiotic beverages with inulin (Villegas et al., 2010) and soy based-beverages (Deshpande et al. 2008).Taking the above into consideration, and aiming to optimize the formulation of a prebiotic low-fat dessert with a blend of short- and long-chain inulin (50:50), this work studies the effect of this inulin blend concentration, and 
its possible interaction with sucrose concentration and lemon flavor, on the acceptability of low-fat desserts.

\section{MATERIAL AND METHODS}

\section{Materials}

The following ingredients were used: whole and skimmed milk powder (Central Lechera Asturiana, Spain), modified tapioca starch $(\mathrm{C} *$ CreamTex 75,720, Cerestar, Spain), two inulin types: long-chain (Frutafit (® TEX) and short-chain (Frutafit ${ }^{\circledR}$ CLR) (Sensus, Brenntag Química, Spain), commercial sucrose, lemon flavor 16508A (Lucta SA, Spain), colorant T-PT8 - WAS (CHR Hansen SA, Spain), mineral water (Font Vella, Spain) and preservatives: potassium sorbate and potassium benzoate (Panreac, Quimica SA, Spain). Both whole (3.7 g fat $/ 100 \mathrm{~g})$ and skimmed milk $(0.11 \mathrm{~g}$ fat $/ 100 \mathrm{~g})$ were prepared $24 \mathrm{~h}$ in advance by dissolving milk powder $(14.4 \mathrm{~g} / 100 \mathrm{~g}$, Central Lechera Asturiana) in mineral water and storing under refrigeration $\left(4 \pm 1^{\circ} \mathrm{C}\right)$.

\section{Experimental design and sample preparation}

For reference sample optimization (regular fat content dessert), a set of samples was prepared with whole milk and varying the concentrations of sucrose and lemon flavor. The composition was selected according to a two-factor central composite design that comprised sixteen points: four factorial, four axial, and eight central points (Table 1).

For prebiotic low-fat dessert optimization, a second set of samples was prepared with skimmed milk and varied concentrations of sucrose, lemon flavor and inulin 
according to a three-factor central composite design with replicates of the central point. It comprised nineteen points: eight factorial, six axial and five central points (Table 2). The inulin used corresponds to a mixture of long-chain and short-chain inulin at a ratio of 50:50. Concentration ranges for inulin (from 3 to 9 $\mathrm{g} / 100 \mathrm{~g}$ ), sucrose (from 4 to $16 \mathrm{~g} / 100 \mathrm{~g}$ ) and lemon flavor (from 25 to $225 \mathrm{mg} / \mathrm{kg}$ ) were established on the basis of preliminary assays. Samples were prepared in batches of 800 g. Starch, sucrose, inulin blend, milk and colorant were weighed in a flask and mixed under magnetic stirring (paddle stirrer, Heidolph RZR 1, Germany) for 10 minutes. The flask was placed in a water bath at $97 \pm 1{ }^{\circ} \mathrm{C}$ and stirred constantly with a propeller stirrer for $25 \mathrm{~min}$. Then the sample was cooled in a water bath at $20^{\circ} \mathrm{C}$ with stirring for 10 minutes. Finally the lemon flavor, preservatives and the amount of water evaporated in the process were added. For samples with inulin, a portion of long-chain inulin $(0.2 \mathrm{~g} / 100 \mathrm{~g}$ of the total weight of sample) was added during sample cooling (seeding).

Preliminary studies have shown that when added in this way, inulin acts as a nucleus of crystallization favoring the formation of more uniform size inulin crystals (Arcia et al., 2010; Glibowski and Pikus, 2010). Finally, the samples were transferred to a closed flask and stored under refrigeration $\left(4 \pm 1^{\circ} \mathrm{C}\right)$.

Sensory evaluation of samples was performed after $48 \mathrm{~h}$ in the case of samples made with whole milk and after 96 hours for the system with skimmed milk and inulin (time to stabilize the samples according a previous work; Arcia et al., 2010) 
Table 1. Experimental design of samples with regular fat content. Coded and uncoded values of levels.

\begin{tabular}{ccccc}
\hline & \multicolumn{2}{c}{ Coded level } & \multicolumn{2}{c}{ Uncoded level } \\
\hline Formulation & Sucrose & Lemon flavor & Sucrose g/100g & Lemon flavor mg/kg \\
\hline 1 & -1 & -1 & 7 & 75 \\
2 & 1 & -1 & 13 & 75 \\
3 & -1 & 1 & 7 & 175 \\
4 & 1 & 1 & 13 & 175 \\
5 & -2 & 0 & 4 & 125 \\
6 & 2 & 0 & 16 & 125 \\
7 & 0 & -2 & 10 & 25 \\
8 & 0 & 2 & 10 & 225 \\
$9-16$ & 0 & 0 & 10 & 125 \\
\hline
\end{tabular}


Table 2. Experimental design of low-fat samples with inulin. Coded and uncoded values of levels.

\begin{tabular}{ccccccc}
\hline & \multicolumn{3}{c}{ Coded level } & & & Uncoded level \\
\hline Formulation & Sucrose & $\begin{array}{c}\text { Lemon } \\
\text { flavor }\end{array}$ & Inulin & $\begin{array}{c}\text { Sucrose } \\
\mathrm{g} / 100 \mathrm{~g}\end{array}$ & $\begin{array}{c}\text { Lemon flavor } \\
\mathrm{mg} / \mathrm{kg}\end{array}$ & $\begin{array}{c}\text { Inulin } \\
\mathrm{g} / 100 \mathrm{~g}\end{array}$ \\
\hline 1 & & -1 & -1 & 7 & 75 & 4.5 \\
2 & 1 & -1 & -1 & 13 & 75 & 4.5 \\
3 & -1 & 1 & -1 & 7 & 175 & 4.5 \\
4 & 1 & 1 & -1 & 13 & 175 & 4.5 \\
5 & -1 & -1 & 1 & 7 & 75 & 7.5 \\
6 & 1 & -1 & 1 & 13 & 75 & 7.5 \\
7 & -1 & 1 & 1 & 7 & 175 & 7.5 \\
8 & 1 & 1 & 1 & 13 & 175 & 7.5 \\
9 & 0 & 0 & 0 & 10 & 125 & 6 \\
10 & -2 & 0 & 0 & 4 & 125 & 6 \\
11 & 2 & 0 & 0 & 16 & 125 & 6 \\
12 & 0 & -2 & 0 & 10 & 25 & 6 \\
13 & 0 & 2 & 0 & 10 & 225 & 6 \\
14 & 0 & 0 & -2 & 10 & 125 & 3 \\
15 & 0 & 0 & 2 & 10 & 125 & 9 \\
$16-19$ & 0 & 0 & 0 & 10 & 125 & 6 \\
\hline
\end{tabular}




\section{Sensory evaluation}

Sensory evaluation was carried out in a standardized test room (ISO 8589, 2007) in a morning session. Samples $(40 \mathrm{~mL})$ were served at $10 \pm 1{ }^{\circ} \mathrm{C}$ in white plastic cups coded with three-digit random numbers. Each consumer evaluated 4 or 5 samples per session presented monadically. Mineral water and bread were provided to consumers to rinse their mouths between samples and a 30 second pause was imposed before they were allowed to test the next sample. In each session sample presentation order was equilibrated among consumers following a Williams design (MacFie et al., 1989).

Acceptability of each sample was evaluated by consumers using a 9-point hedonic scale ( 1 = "I dislike extremely", 9 = "like extremely"). A total of 124 subjects participated in the study. They were usual consumers of semisolid dairy desserts (at least once a week). In the case of reference sample optimization, each whole milk sample (Table 1) was evaluated at least by 60 consumers (from 60 to 62 ). For optimization of the prebiotic low-fat dessert (Table 2), each sample was evaluated by at least 84 consumers (from 84 to 89 ).

Finally, two weeks later the low-fat dessert and the reference full-fat dessert were produced with their respective optimized formulations, and compared. A total of 60 consumers evaluated for preference and differences in the intensity of samples by paired comparison tests in one session (ISO 5495, 2005). For that, the two samples were presented simultaneously to consumers and they were asked to select the most preferred sample and then the sample with more intense lemon flavor, sweetness and consistency.

Data were processed by Compusense ${ }^{\circledR}$ five release 4.6 software (Compusense Inc., Guelph, Ontario, Canada). 


\section{Data analysis}

One way analysis of variance (ANOVA) was performed on acceptability data to study the formulation effect. Homogeneity of variances was analyzed using Barlett test. Differences between samples were determined by the Fisher test ( $\alpha \leq$ 0.05). XLSTAT-Pro Version 2007 (Addinsoft, Paris, France) was used.

In the optimization study, the results were analyzed using Response Surface Methodology (RSM) (Gacula, 1993). Overall acceptability and composition data were submitted to a multivariate regression analysis and fitted to a second-order model equation provided in the design:

$\mathrm{Y}=\mathrm{B}_{0}+\mathrm{B}_{1} \mathrm{X}_{1}+\mathrm{B}_{2} \mathrm{X}_{2}+\mathrm{B}_{3} \mathrm{X}_{3}+\mathrm{B}_{11} \mathrm{X}_{1}^{2}+\mathrm{B}_{22} \mathrm{X}_{2}^{2}+\mathrm{B}_{33} \mathrm{X}_{3}^{2}+\mathrm{B}_{12} \mathrm{X}_{12}+\mathrm{B}_{13} \mathrm{X}_{13}+\mathrm{B}_{23} \mathrm{X}_{23}+$ Error (Ec. 1)

where $\mathrm{Y}$ is the acceptability, $\mathrm{B}_{0}$ is the intercept (constant), $\mathrm{B}_{1}, \mathrm{~B}_{2}, \mathrm{~B}_{3}$ the linear, $\mathrm{B}_{11}, \mathrm{~B}_{22}, \mathrm{~B}_{33}$ the quadratic and $\mathrm{B}_{12}, \mathrm{~B}_{13}, \mathrm{~B}_{23}$ the interaction effects, $\mathrm{X}_{1}, \mathrm{X}_{2}$ and $\mathrm{X}_{3}$ the independent variables: concentrations of sucrose (S), lemon flavor (L) and inulin (I) respectively. The software SPSS for windows 13.0 (SPSS Inc., Chicago, IL, USA) was used.

The significance of differences in sensory properties in the paired comparisons test were established for $\alpha=0.05$ using the Compusense ${ }^{\circledR}$ five release 5.0 software (Compusense Inc., Guelph, Ontario, Canada). 


\section{RESULTS AND DISCUSSION}

\section{Acceptability of desserts with regular fat content: Reference sample optimization}

Before optimizing the formulation of the prebiotic low-fat dairy dessert, the most suitable sucrose and lemon flavor concentrations for a dairy dessert with regular fat content $(2.8 \mathrm{~g} / 100 \mathrm{~g}$ fat $)$ was determined in order to use it as the reference sample. To do so, we evaluated the acceptability of samples with whole milk and different sucrose and lemon flavor levels, selected according to the RSM design (Table 3). Analysis of variance showed that the degree of liking differed significantly among these samples $(\mathrm{F}=12.23, \mathrm{p}<0.001)$ with scores ranging from 4.4 to 7 . To relate the differences in acceptability with sample composition, data were fitted to a second-order model. In the selected model, only the statistically significant terms were retained and their corresponding coefficients are shown in Table 4 . Thus, the equation that represents the relationship between acceptability and concentrations of sucrose $(\mathrm{S}, \mathrm{g} / 100 \mathrm{~g})$ and lemon flavor (L, $\mathrm{mg} / \mathrm{kg}$ ) is as follows:

$$
\text { Acceptability }=0.088+0.014 \mathrm{~L}+1.056 \mathrm{~S}-0.046 \mathrm{~S}^{2}-4.96 * 10^{-5} \mathrm{~L}^{2}
$$

$$
\text { (Adjusted } \mathrm{R}^{2}=0.889 \text { ) }
$$

The model was significant $(\mathrm{p}=0.002)$ and explained $96.1 \%$ of all variance in data. The lack of fit was significant $(\mathrm{p}=0.042)$ indicating that variability not explained by model was attributed mostly to the lack of fit of some data than to the pure error. On observing predicted data, the acceptability of sample 1 was shown to be lower (6.02) than the experimental value (6.47). The model does not have enough flexibility to fit acceptability values for samples with low flavor and 
sucrose levels for which it would be expected to obtain higher acceptability values than those predicted by the model.

Table 3. Acceptability of regular fat dairy desserts with different sucrose and lemon flavor concentrations ${ }^{1}$.

\begin{tabular}{cc}
\hline Sample & Acceptability \\
\hline 1 & $6.48^{\mathrm{bcd}}$ \\
2 & $6.97^{\mathrm{ab}}$ \\
3 & $6.41^{\mathrm{cd}}$ \\
4 & $6.87^{\mathrm{bc}}$ \\
5 & $4.35^{\mathrm{e}}$ \\
6 & $6.23^{\mathrm{d}}$ \\
7 & $6.10^{\mathrm{d}}$ \\
8 & $6.82^{\mathrm{abc}}$ \\
9 & $7.19^{\mathrm{a}}$ \\
10 & $7.13^{\mathrm{a}}$ \\
11 & $6.92^{\mathrm{abc}}$ \\
12 & $6.98^{\mathrm{ab}}$ \\
13 & $7.05^{\mathrm{ab}}$ \\
14 & $6.97^{\mathrm{ab}}$ \\
15 & $6.82^{\mathrm{abc}}$ \\
16 & $6.97^{\mathrm{ab}}$ \\
$\mathrm{P}_{\text {ANOVA }}($ sample) (sa(sample) & $<0.001$ \\
$\mathrm{P}_{\text {Bartlett Test }}($ sample) (sample) & $0.059^{\mathrm{a}}$
\end{tabular}

${ }^{\mathrm{a}-\mathrm{e}}$ Fisher's significant differences: acceptability values not shearing letters are significant different.

${ }^{1}$ Identification of samples in Table 1. 
Table 4. Estimated regression coefficients of the fitted equations obtained for the acceptability of regular fat samples depending on sugar (1) and lemon flavor (2) concentration.

\begin{tabular}{lcccc}
\hline & \multicolumn{2}{c}{ ANOVA } & \multicolumn{2}{c}{ Coefficients } \\
\cline { 2 - 5 } Item & F-values & P-values & Estimated Values & Standard error \\
\hline $\mathrm{B}_{0}$ & & & 0.088 & 0.638 \\
Linear & 104.78 & $<0.001$ & 1.056 & 0.103 \\
$\mathrm{~B}_{1}$ & 9.39 & 0.011 & 0.014 & 0.005 \\
$\mathrm{~B}_{2}$ & & & & \\
Cuadratic & 84.50 & $<0.001$ & -0.046 & 0.005 \\
$\mathrm{~B}_{11}$ & 7.50 & 0.019 & $-5 \times 10^{-5}$ & $2 \times 10^{-5}$ \\
$\mathrm{~B}_{22}$ & & & & \\
\hline
\end{tabular}

Both lemon flavor concentration and sucrose concentration significantly affected product acceptability, with a positive coefficient for the linear term and a negative coefficient for the quadratic term. As can be seen in the surface generated by the model (Figure 1), acceptability showed an inverted-U shape relationship with the concentration of both lemon flavor and sucrose. As the concentration increased acceptability increased until reaching a certain concentration, at which point if leveled off (maximum in increased) and decreased downward to low acceptability values. The contours plot created by the predictive model (Figure 2) indicated that highest acceptability would be obtained for desserts produced with sucrose content in the range of 10.2 to $12.5 \mathrm{~g} / 100 \mathrm{~g}$ and with lemon flavor content in the range of 112 to $180 \mathrm{mg} / \mathrm{kg}$. For both, sucrose and lemon flavor, the concentration for maximum acceptability was the value at which the equation first derivative equals zero. According to the results, the formulation with a concentration of $11.5 \mathrm{~g} / 100 \mathrm{~g}$ sucrose and $145 \mathrm{mg} / \mathrm{kg}$ of lemon flavor was selected as the reference sample with regular fat content. 


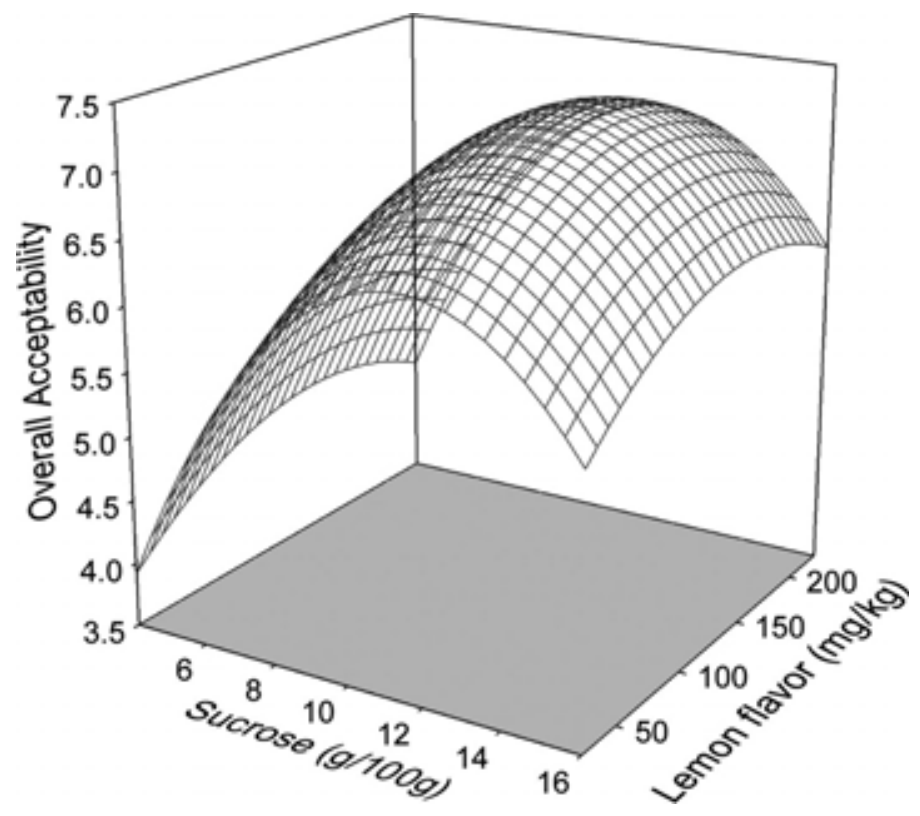

Figure 1. Response surface for the effects of sucrose concentration and lemon flavor concentration on acceptability of regular fat content dairy desserts.

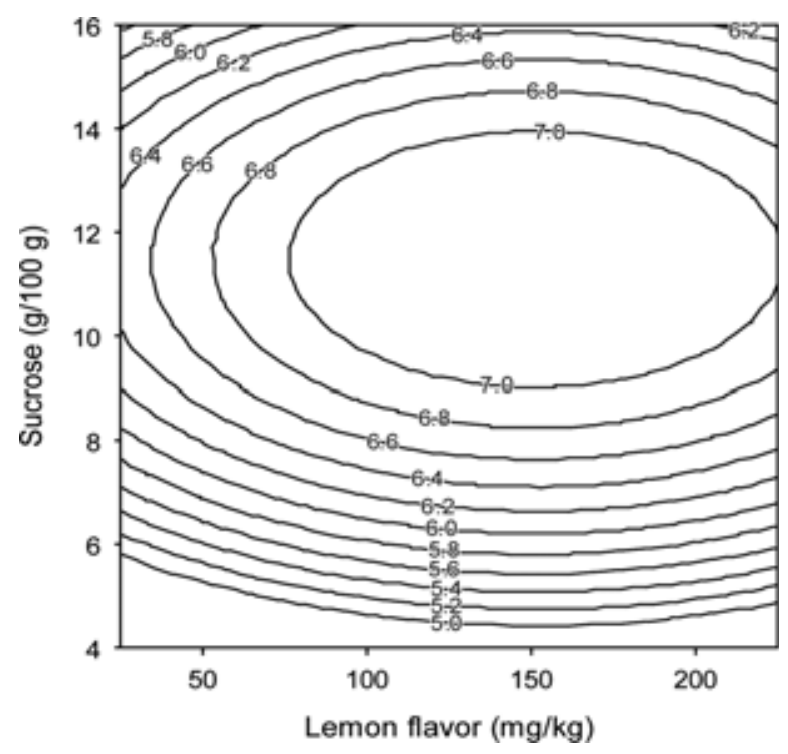

Figure 2. Contour plot of the acceptability of regular fat content dairy dessert as related to sucrose and lemon flavor concentration. 


\section{Acceptability of low-fat desserts with inulin. Formulation optimization}

Acceptability of low-fat samples with different concentrations of inulin, sucrose and lemon flavor was evaluated by consumers. Significant differences in the mean score were observed among samples $(\mathrm{F}=6.2 ; \mathrm{p}<0.001)$ with values ranging from 5 to 6.7 (Table 5).

To explain and model the variation in acceptability in terms of composition variables, data were fitted to a second-order equation for the 3 variables. The significant terms and values of the coefficients of the model that best fits are indicated in Table 6. For both sucrose and inulin, the linear and the quadratic terms were found to be significant. The coefficients for the linear terms were positive and for the quadratic were negative. The term associated with the interaction between the effects of both ingredients was significant and presented a coefficient with negative sign. In the case of lemon flavor, only the quadratic term was significant, with a negative coefficient. Thus, the equation that represents the relationship between overall acceptability and concentrations of inulin $(\mathrm{I}, \mathrm{g} / 100 \mathrm{~g})$, sucrose $(\mathrm{S}, \mathrm{g} / 100 \mathrm{~g})$ and lemon flavor $(\mathrm{L}, \mathrm{mg} / \mathrm{kg})$ is as follows:

$$
\text { Acceptability }=0.391+0.869 \mathrm{~S}+0.630 \mathrm{I}-9.06 * 10^{-6} \mathrm{~L}^{2}-0.033 \mathrm{~S}^{2}-0.028 \mathrm{I}^{2}-0.031 \mathrm{SI}
$$

$$
\text { (Adjusted } \mathrm{R}^{2}=0.886 \text { ) }
$$

The obtained model was significant $(\mathrm{p}<0.001)$, it did not present lack of fit $(\mathrm{p}=$ 0.055) and it could explain $96.1 \%$ of all variance in data. According to the model, overall acceptability of low-fat dessert was mainly affected by inulin and sucrose concentration. The effects of these two variables on acceptability can be observed in Figure 3. As observed for regular fat content desserts, acceptability had an inverted-U shape relationship with sucrose concentration. In this case, due to the inulin-sucrose interaction effect, a maximum was reached at different 
sucrose concentration values depending on inulin concentration. The interaction effect was even more evident in the case of the effect of inulin concentration, which changed depending on sucrose concentration. For low sucrose levels, the increase in inulin concentration led to an increase in acceptability, while for high sucrose levels acceptability decreased. The contribution of short-chain inulin molecules to sweetness intensity (Franck, 2002) seems to underlie this interaction. For low sucrose level samples, the addition of inulin can compensate the lack of sweetness, thus increasing its acceptability while using high levels of both ingredients led to a decrease in acceptability due to excessive sweetness. The variation in lemon flavor concentration, within the ranges employed in this study, hardly affected acceptability, as indicated by the low coefficient value for this component. 
Table 5. Acceptability of low-fat dairy desserts with different inulin, sucrose and lemon flavor concentrations ${ }^{1}$.

\begin{tabular}{cc}
\hline Sample & Acceptability \\
\hline 1 & $6.29^{\mathrm{abcd}}$ \\
3 & $6.47^{\mathrm{abc}}$ \\
4 & $5.90^{\mathrm{de}}$ \\
5 & $6.24^{\mathrm{abcd}}$ \\
6 & $6.51^{\mathrm{abc}}$ \\
7 & $6.10^{\mathrm{bcde}}$ \\
8 & $6.23^{\mathrm{abcd}}$ \\
9 & $6.05^{\mathrm{cde}}$ \\
10 & $6.56^{\mathrm{ab}}$ \\
11 & $5.03^{\mathrm{g}}$ \\
12 & $5.68^{\mathrm{ef}}$ \\
13 & $6.56^{\mathrm{ab}}$ \\
14 & $6.18^{\mathrm{abcd}}$ \\
15 & $6.33^{\mathrm{abcd}}$ \\
16 & $6.23^{\mathrm{abcd}}$ \\
17 & $6.65^{\mathrm{a}}$ \\
18 & $6.62^{\mathrm{a}}$ \\
19 & $6.49^{\mathrm{abc}}$ \\
$\mathrm{P}_{\text {ANOvA }}($ sample) (sa(sample) & $6.61^{\mathrm{a}}$ \\
$\mathrm{P}_{\text {Bartlett Test }}(\mathrm{sample})($ sample $)$ & $<0.001$ \\
\hline
\end{tabular}

${ }^{\mathrm{a}-\mathrm{g}}$ Fisher's significant differences: acceptability values not shearing letters are significant different.

${ }^{1}$ Identification of samples in Table 2 
Table 6. Estimated regression coefficients of the fitted equations obtained for the acceptability of the prebiotic low-fat dairy dessert depending on sugar (1), lemon flavor (2) and inulin (3) concentration.

\begin{tabular}{lcccc}
\hline & \multicolumn{2}{c}{ ANOVA } & \multicolumn{2}{c}{ Coefficients } \\
\cline { 2 - 5 } Item & F-values & $\mathrm{p}$-values & Estimated Values & Standard error \\
\hline $\mathrm{B}_{0}$ & & & 0.350 & 0.829 \\
Linear & & & & \\
$\mathrm{B}_{1}$ & 102.66 & $<0.001$ & 0.866 & 0.086 \\
$\mathrm{~B}_{3}$ & 13.74 & 0.003 & 0.649 & 0.175 \\
Cuadratic & & & & \\
$\mathrm{B}_{11}$ & 132.62 & $<0.001$ & -0.033 & 0.003 \\
$\mathrm{~B}_{22}$ & 11.46 & 0.0054 & $-9 \times 10^{-6}$ & $3 \times 10^{-6}$ \\
$\mathrm{~B}_{33}$ & 6.99 & 0.0214 & -0.031 & 0.012 \\
Interaction & & & & 0.010 \\
$\mathrm{~B}_{13}$ & 7.79 & 0.016 & -0.029 & \\
\hline
\end{tabular}




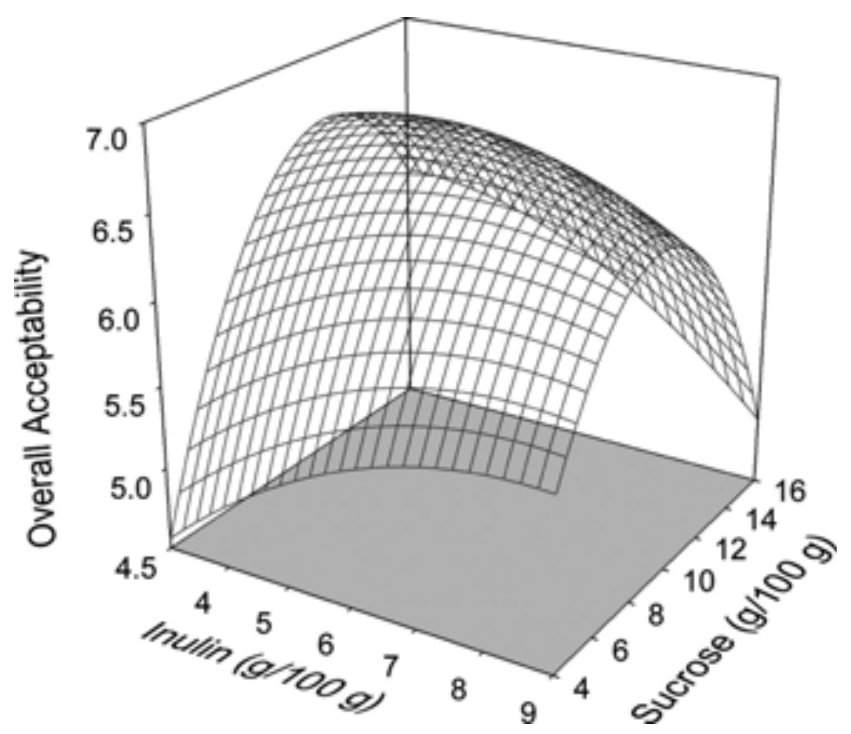

Figure 3. Response surface for the effects of inulin concentration and sucrose concentration on acceptability of low-fat dairy dessert (lemon flavour concentration $=125 \mathrm{mg} / \mathrm{kg}$ ).

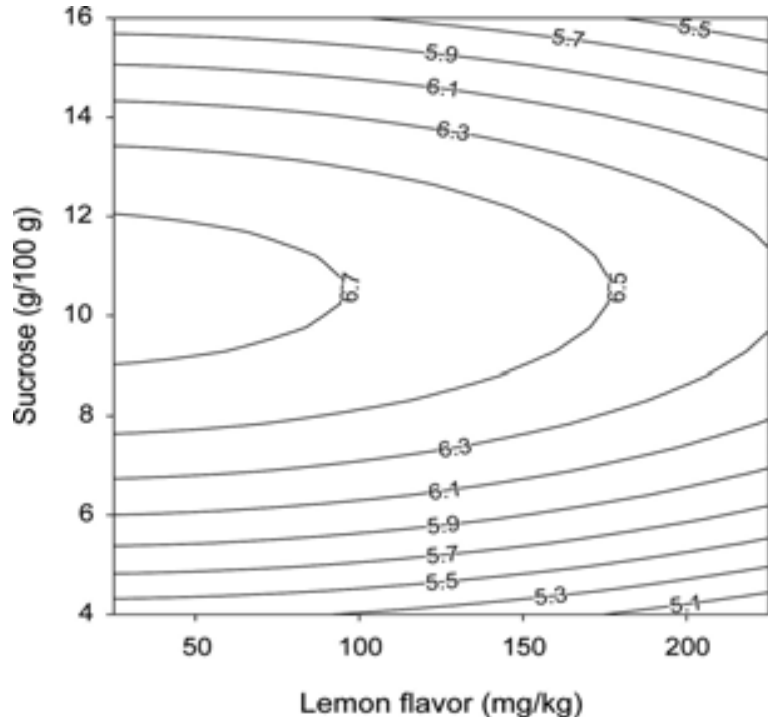

Figure 4. Contour plot of the acceptability of prebiotic low-fat dairy dessert as related to lemon flavor and sucrose concentration (inulin concentration $=6$ $\mathrm{g} / 100 \mathrm{~g})$. 
The concentration ranges of each ingredient for maximum acceptability were determined using contour plots of the obtained model. It was decided to determine the concentration range for lemon flavor first because it was independent on the other ingredients (no significant interactions). According to Figure 4, maximum acceptability values are obtained for lemon flavor concentrations between 25 and $95 \mathrm{mg} / \mathrm{kg}$.

At this point, it is interesting to compare Figure 4 with Figure 2, which shows the contour of maximum acceptability, for regular fat content desserts, at somewhat higher levels of lemon flavor (between 112 and $180 \mathrm{mg} / \mathrm{kg}$ ). These higher values of lemon flavor concentration in the formulation of regular fat desserts show the effect of fat as a suppressor of aroma release and flavor perception (Weel et al., 2002; González-Tomás et al., 2007; Tarrega et al., 2008).

The optimum ranges for inulin and sucrose were studied in the contour graph for a lemon flavor of $75 \mathrm{mg} / \mathrm{kg}$ (Figure 5). According to this graph, the range of sucrose for which acceptability is highest is between 9 and $12 \mathrm{~g} / 100 \mathrm{~g}$ and for inulin between 4 and $6.5 \mathrm{~g} / 100 \mathrm{~g}$. A representative formulation with maximum acceptability was selected by fixing lemon flavor content at the midpoint of the optimum range and calculating both sucrose and inulin concentration as the value at which the equation first derivative equals zero. The resulting formulation was composed of $10 \mathrm{~g}$ sucrose $/ 100 \mathrm{~g}, 60 \mathrm{mg}$ lemon flavor $/ \mathrm{kg}$ and $5.5 \mathrm{~g}$ inulin $/ 100 \mathrm{~g}$.

The practical use of contour plots is of interest, serving as a database of the acceptability value corresponding to several formulation options. Thus changes in formulation can be proposed that maintain a balance between acceptability levels and either economic or nutritional benefits. As can be seen, the inulin blend (50:50) can be added at a wide concentration range (from 3 to $7.5 \mathrm{~g} / 100 \mathrm{~g}$ ), giving rise to dairy desserts with high levels of acceptability ( $>6.6$ ) provided formulation sugar content is taken into account. For example, for desserts with $3.5 \mathrm{~g}$ inulin/100g, sucrose content should be in the range of 10.5 and $13.0 \mathrm{~g} / 100 \mathrm{~g}$ 
while for samples with higher inulin content $(7.0 \mathrm{~g} / 100 \mathrm{~g})$ the sucrose concentration range moves to lower values $(8.5-11.5 \mathrm{~g} / 100 \mathrm{~g})$.

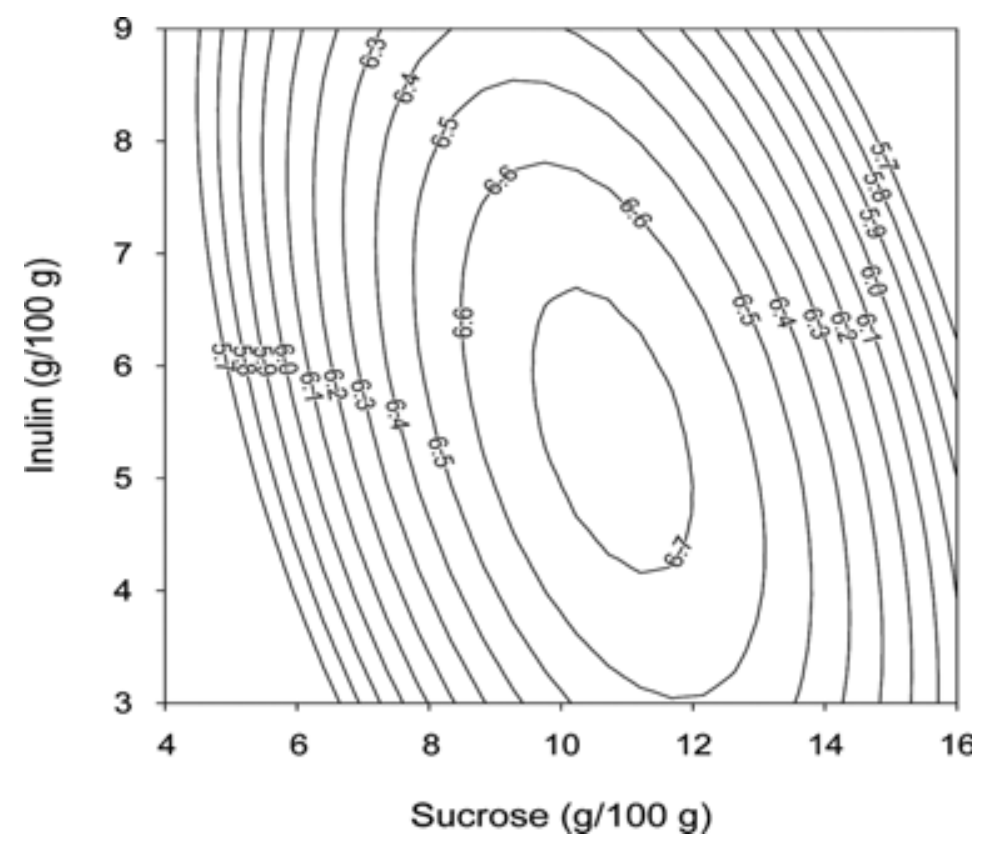

Figure 5. Contour plot of acceptability of prebiotic low-fat dairy dessert as related to sucrose and inulin concentrations (lemon flavor concentration $=75$ $\mathrm{mg} / \mathrm{kg})$.

Comparison between the prebiotic low-fat dairy dessert and the regular fat content dessert

A low-fat dessert was produced with the selected levels of inulin, sucrose and lemon flavor and compared with the reference dessert with regular fat content. Differences in the intensity of some attributes and overall acceptability were evaluated (Figure 6). The prebiotic low-fat dessert was creamier and thicker than the reference full-fat sample Taking into account that thickness and creaminess in 
a low-fat custard are lower than those of a regular fat sample (Tarrega and Costell, 2006) this result indicated that $5.5 \mathrm{~g} / 100 \mathrm{~g}$ of the inulin blend (50:50) increased viscosity and creaminess of low fat dessert enough to exceed those of full-fat sample. The lemon flavor was perceived less intense in the full-fat sample although it contained twice the concentration of the low fat sample. This difference can be due to both the flavor retention effect of fat in the whole milk sample and the effect of inulin as flavor enhancer in the prebiotic sample (Tarrega and Costell, 2006). Regarding sweetness, the prebiotic low-fat dessert contained less sucrose than the reference sample; no difference was found in perceived sweetness between them, which can be attributed to the sweetener effect of short-chain inulin. In spite of the fact that differences in the sensory characteristics were perceived by consumers, they found the low-fat dessert to be as acceptable as the regular fat dessert.

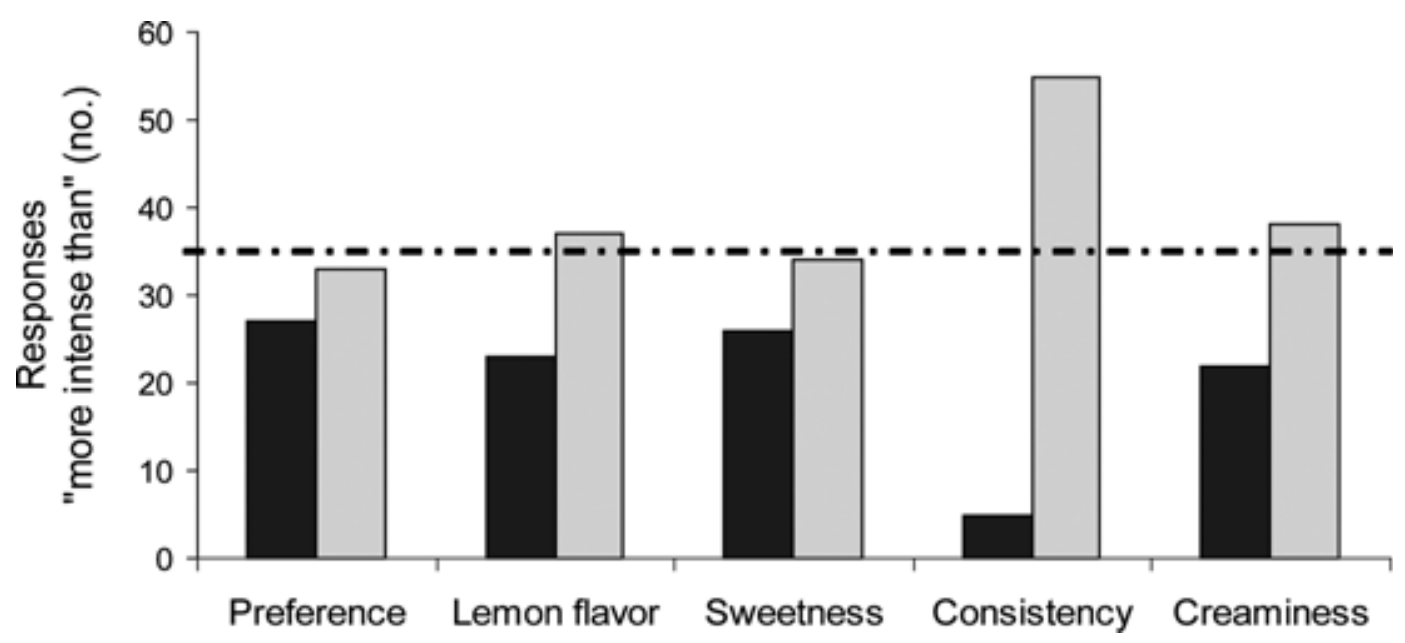

Figure 6. Sensory comparison of the low-fat dairy dessert (grey bars) and the dessert with regular fat content (black bars). The dotted line indicates the minimum value of response for which the difference is significant $(\alpha=0.05)$. 


\section{CONCLUSIONS}

In low-fat dairy desserts, the addition of an inulin blend (short- and long-chain) affects acceptability. The effect is dependent not only on the concentration of added inulin but also on the sugar concentration.

The relationship between the acceptability of low-fat dairy desserts and composition has been established. The obtained model predicts acceptability in terms of the concentration of sucrose, inulin and lemon flavor.

The prebiotic low-fat dairy dessert selected in the optimization study, besides the reduction in the amount of fat, also contained less sugar (12\% reduction) and less lemon flavor (60\% reduction) than the reference product (regular fat content), without its acceptability degree being affected.

\section{ACKNOWLEDGMENTS}

The financial support of MICIN, Spain (Project AGL 2007-63444 and Tarrega's contract within the Juan de la Cierva Programme) and financial support of LATU, Uruguay for Arcia's stay at IATA, Valencia, and the support of CHR Hansen S.A., Lucta S.A., Brenntag Química and Central Lechera Asturiana for providing free samples of the ingredients, are all gratefully acknowledged.

\section{REFERENCES}

Abrams, S. A., I. J. Griffin, K. M. Hawthorne, L. Liang, S. K. Gunn, and G. Darlington. 2005. A combination of prebiotic short- and long-chain inulin- 
type fructans enhances calcium absorption and bone mineralization in young adolescents. Am. J. Clin. Nutr. 82(2): 471-476.

Acosta, O., F. Víquez, and E. Cubero. 2008. Optimisation of low calorie mixed fruit jelly by response surface methodology. Food Qual Prefer. 19 (1): 7985.

Arcia, P. L., S. Navarro, J. Catalá, E. Costell, and A. Tárrega. 2010. Using seeding technique in the manufacture of inulin enriched dairy desserts. In Conference Proccedings of Food Innova 2010, 193. Valencia, Spain.

Bayarri, S., I. Chuliá, and E. Costell. 2010. Comparing $\lambda$-carrageenan and an inulin blend as fat replacers in carboxymethyl cellulose dairy desserts. rheological and sensory aspects. Food Hyd. 24(6-7): 578-587.

Biedrzycka, E., and M. Bielecka. 2004. Prebiotic effectiveness of fructans of different degrees of polymerization. Trends Food Sci. Technol.15(3-4): 170-175.

Cardarelli, H. R., F. C. A. Buriti, I. A. Castro, and S. M. I. Saad. 2008. Inulin and oligofructose improve sensory quality and increase the probiotic viable count in potentially synbiotic petit-suisse cheese. Food Sci. Technol. 41: 1037-1046.

Coudray, C., J. C. Tressol, E. Gueux, and Y. Rayssiguier. 2003. Effects of inulintype fructans of different chain length and type of branching on intestinal absorption and balance of calcium and magnesium in rats. Eur. J. Nutr. 42(2): 91-98.

Damasio, M. H., E. Costell, and L. Duran. 1999. Optimising acceptability of lowsugar strawberry gels segmenting consumers by internal preference mapping. J. Sci. Food Agric. 79 (4): 626-632.

De Castro, T. M., P. L. M., Cunha, R. D. Barreto, D. M. Amboni, and E. S. Prudencio. 2009. Effect of oligofructose incorporation on the properties of fermented probiotic lactic beverages. Int. J. Dairy Techol. 62: 68-74. 
Deshpande, R. P., M. S. Chinnan, and K. H. McWatters. 2008. Optimization of a chocolate-flavored, peanut-soy beverage using response surface methodology (RSM) as applied to consumer acceptability data. LWT Food Sci. Technol. 41 (8): 1485-1492.

Franck, A. 2002. Technological functionality of inulin and oligofructose. Br. J. Nutr. 2: 287-291.

Gacula, M. 1993. Design and analysis of sensory optimization. Trumbull: Food and Nutrition Press.

Gan, H.E., R. Karim, S.K.S. Muhammad, J.A. Bakar, D.M. Hashim, and R. Rahman. 2006. Optimization of the basic formulation of a traditional baked cassava cake using response surface methodology. LWT - Food Sci Technol. 40 (4): 611-618.

Ghoddusi, H. B., M. A. Grandison, A. S. Grandison, and K. M. Tuohy. 2007. In vitro study on gas generation and prebiotic effects of some carbohydrates and their mixtures. Anaerobe. 13(5-6): 193-199.

Glibowski, P., and S. Pikus. 2011. Amorphous and crystal linulin behaviour in a water environment. Carbohydr Polym. 83 (2): 636, 639.

González-Tomás, L., S. Bayarri, A. J. Taylor, and E. Costell. 2007. Flavour release and perception from model dairy custards. Food Res. Int.. 40: 520528.

Gonzalez-Tomas, L., S. Bayarri, and E. Costell. 2009. Inulin-Enriched Dairy Desserts: Physicochemical and Sensory Aspects. J. Dairy Sci. 92: 41884199.

Granato, D., I. A. Castro, L. S. N. Ellendersen, and M. L. Masson. 2010. Physical stability assessment and sensory optimization of a dairy-free emulsion using response surface methodology. J. Food Sci. 73: 49-155. 
Granato, D., J. C. B. Ribeiro, I. A. Castro, and M. L. Masson. 2010. Sensory evaluation and physicochemical optimisation of soy-based desserts using response surface methodology. Food Chem. 121: 899-906.

ISO, International Standard 5495. 2005. Sensory analysis. Methodology. Paired comparison test. Ref. No. ISO 5495:2005. Genève: International Organization for Standardization.

ISO, International Standard 8589. 2007. Sensory analysis. General guidance for the design of test rooms. Ref. No. ISO 8589:2007. Genève: International Organization for Standardization.

Kip, P., D. Meyer, and R. H. Jellema. 2006. Inulins improve sensoric and textural properties of low-fat yoghurts. Int. Dairy J. 16: 1098-1103.

Lobato, L. P., M. V. E. Grossmann, and M. T. Benassi. 2009. Inulin addition in starch-based dairy desserts: Instrumental texture and sensory aspects. Food Sci. Technol. Int. 15: 317-323.

MacFie, H. J., N. Bratchell, K. Greenhoff, and L. V. Vallis. 1989. Designs to balance the effect of order of presentation and first-order carry over effects in Hall Tests. J Sens. Stud. 4: 129-148.

Modzelewska-KapituŁa, M., KŁȩbukowska, L. 2009. Investigation of the potential for using inulin HPX as a fat replacer in yoghurt production. Int. J. Dairy Technol., 62(2): 209-214.

Roberfroid, M., J. Van Loo, and G. Gibson. 1998. The bifidogenic nature of chicory inulin and its hydrolysis products. J. Nutr. 128: 11-19.

Tárrega, A., and E. Costell. 2006. Effect of inulin addition on rheological and sensory properties of fat-free starch-based dairy desserts. Int. Dairy J. 16:1104-1112.

Tarrega, A., C. Yven, E. Sémon, and C. Salles. 2008. Aroma release and chewing activity during eating different model cheeses. Int. Dairy. J. 18: 849-857. 
Tárrega, A., A. Rocafull, and E. Costell. 2010. Effect of blends of short and longchain inulin on the rheological and sensory properties of prebiotic low-fat custards. Food Sci Technol Bull. 43(3): 556-562.

Tungland, B., and D. Meyer. 2002. Non-digestible Oligosaccharides (Dietary Fibre): Their Physiology and Role in Human Health and Food. Compr. Rev. Food Sci Food Saf. 3: 73-92.

Villegas, B., A. Tárrega, I. Carbonell, and E. Costell. 2010. Optimising acceptability of new prebiotic low-fat milk beverages. Food Qual. Prefer. 21(2): 234-242.

Weel, K. G. C., A. E. M. Boelrijk, A. C. Alting, P. J. J. M. Van Mil, J. J. Burger, H. Gruppen, A. G. J. Voragen, and G. Smit. 2002. Flavor release and perception of flavored whey protein gels: perception is determined by texture rather than by release. J. Agric. Food Chem. 50: 5149-5155. 


\section{RESUMEN DE RESULTADOS}



La elección, compra y aceptación de los alimentos es el resultado de un proceso complejo en cuyo resultado inciden factores de distintos tipos, tal como se ha comentado en la introducción de esta tesis. Lógicamente, el análisis de de la influencia de factores de distinta naturaleza implica la puesta a punto y la utilización de diferentes técnicas. En este contexto, y de acuerdo con el objetivo general de esta tesis, se han realizado una serie de experiencias cuyos resultados se pueden agrupar en tres áreas temáticas: 1) La investigación de las opiniones y actitudes de los consumidores sobre alimentos con características nutricionales específicas; 2) El estudio de los distintos factores que influyen en la intención de compra y en la aceptación o rechazo de un producto comercial bajo en grasa y 3 ) El desarrollo y optimización de la calidad sensorial de un nuevo producto funcional en función de las preferencias del consumidor

\section{Investigación de las opiniones y actitudes de los consumidores sobre alimentos con características nutricionales específicas}

En primer lugar se estudió y analizó la opinión de consumidores uruguayos acerca de quesos con diferentes características funcionales. El estudio se llevó a cabo en dos tipos de queso de consumo habitual en Uruguay: el queso para untar y el queso Dambo. Se evalúo el grado de interés de un grupo de consumidores Uruguayos $(n=162)$, en quesos con distintas características funcionales (bajo en grasa, reducido en sal, con fibra y probióticos) y se comparó con su interés en los quesos de composición convencional y habituales en el mercado. Paralelamente, se investigó también su opinión sobre dos tipos de elaboración (industrial y artesanal). Utilizando la técnica de análisis conjunto se pudo determinar el valor que los consumidores asignaron a cada una de las características que se le 
presentaron. Para los dos tipos de queso estudiados, los resultados indicaron que la opinión y el interés de los consumidores dependieron en gran medida del tipo de beneficio nutricional y en menor medida, del tipo de elaboración. En general, al considerar conjuntamente los resultados de todo el grupo de consumidores se observó que estaban más interesados en el queso habitual que en los quesos con características funcionales. No obstante, al segmentar la población se detectaron grupos de consumidores con distinta opinión y actitud sobre los quesos funcionales. Un grupo importante de consumidores (alrededor del 40\%) mostró el mismo interés por ciertos quesos funcionales que por los quesos convencionales. Otro grupo de consumidores, además del interés por los quesos convencionales, mostró también interés por los quesos con bajo contenido en grasa. Un tercer grupo de consumidores no mostró ningún interés por ninguno de los quesos con carácter funcional. A diferencia de lo observado por Ares et al. (2010), en su estudio sobre yogur, la presencia de un beneficio funcional en los quesos no fue considerado por los consumidores uruguayos como un valor añadido para el producto. Esta diferencia en la respuesta de los consumidores puede deberse al tipo de producto (Urala and Lähteenmäki, 2007). El queso es un producto considerado tradicional cuyas características sensoriales son apreciadas por el consumidor que, en principio prefiere el producto habitual y es poco favorable a la modificación de su formulación.

Posteriormente, se analizaron las razones de los consumidores uruguayos para comprar o no quesos funcionales. Mediante la técnica de escalamiento o "laddering" se estableció cómo los consumidores interpretaban las características de cada producto funcional y las asociaban con consecuencias y valores importantes para él. En general, los motivos de los consumidores para comprar un queso funcional se centraron en lograr una mejor calidad de vida o una buena imagen física. Por otro lado, la duda respecto a las posibles características 
sensoriales del producto y la desconfianza en el efecto real del producto en la salud fueron los principales motivos que los consumidores alegaron para no comprar queso con alguna característica funcional.

\section{Factores que influyen en la intención de compra y en la aceptación o rechazo de un producto comercial bajo en grasa: El queso magro de Uruguay}

Esta parte de la tesis se llevó a cabo utilizando seis muestras comerciales de queso magro uruguayo. En una primera etapa, se estudió la relación entre las variaciones en las características sensoriales y la aceptabilidad. Las muestras comerciales presentaron diferencias tanto en composición como en textura instrumental. La intensidad de las características sensoriales percibida en cada una de las seis muestras se cuantificó mediante un panel de jueces entrenados. De acuerdo al perfil sensorial de las muestras, el queso magro uruguayo se caracteriza por tener olor y sabor suaves, una firmeza intermedia, una elasticidad de media a alta y por ser poco friable. Las mayores diferencias entre los quesos se detectaron en su textura, principalmente en la firmeza y en la elasticidad, mientras que las diferencias en sabor no fueron importantes. El grado de aceptabilidad evaluado por los consumidores, varió significativamente entre los quesos comerciales. A pesar de que las mayores diferencias entre los quesos se habían observado en los atributos de textura, los atributos del sabor fueron los que mas influyeron en las diferencias detectadas en la aceptabilidad de las muestras. Las muestras más aceptables fueron las que tenían una mayor intensidad de olor y de sabor y una menor intensidad de sabor amargo. 
Dado que en este trabajo se analizaban productos comerciales, se consideró interesante estudiar cómo las características de la etiqueta influían en la aceptabilidad del producto. Así, en esta segunda etapa se estudió cómo las expectativas creadas por la etiqueta influían en la aceptabilidad y en la intención de compra del producto. Los consumidores evaluaron los seis quesos comerciales bajos en grasa en diferentes condiciones: 1) Producto codificado, sin información adicional sobre sus características (en ciego); 2) Evaluación de la etiqueta y 3) Evaluación del producto con su etiqueta. Cuando los consumidores evaluaron cada producto con su etiqueta, el nivel de agrado aumentó o se mantuvo respecto al obtenido en la evaluación a ciegas pero, en ningún caso, disminuyó. Esto sugiere que, en este caso, las características de la etiqueta solo tuvieron un efecto positivo o neutro en la percepción hedónica de los consumidores. Cuando las expectativas generadas por la etiqueta no se confirmaban en el producto, la respuesta del consumidor seguía un modelo de asimilación que, según la muestra, era completa o incompleta. Cuando la no confirmación de la expectativa tuvo un carácter positivo (al probar el producto éste se evaluó mejor de lo esperado) tuvo un efecto positivo en la aceptabilidad de los quesos, lo que coincide con lo observado por algunos autores en diferentes tipos de productos (Cardello et al. 1994; Monaco et al., 2004; Varela et al., 2010; Villegas et al., 2008). La marca comercial y el aspecto fueron las características de la etiqueta que más influyeron en la intención de compra. Los motivos principales de los consumidores para elegir un queso fueron la confianza en la marca o en las posibles características sensoriales del queso y el diseño de la etiqueta (imagen del queso). 


\section{Desarrollo y optimización de la calidad sensorial de un nuevo producto funcional en función de las preferencias del consumidor}

La idea central de esta parte de la tesis era estudiar la adecuación de la inulina para desarrollar un postre lácteo funcional con carácter prebiótico y bajo en grasa que fuera aceptable para los consumidores. En primer lugar se estudió el efecto de la adición de inulina de cadena larga en las propiedades reológicas y en la microestructura de sistemas modelo de postres lácteos semisólidos. Se observó que durante el almacenamiento se producía la formación de cristales de inulina de tamaño heterogéneo que por un lado, incrementaban la viscosidad y la elasticidad del producto pero por otro disminuían la sensación de suavidad y producían una sensación de arenosidad no deseable. Para subsanar estos defectos, primero se estudiaron los factores que influían en la cristalización de inulina en este tipo de productos. La distribución del tamaño de partícula dependió de la concentración de inulina y de la presencia de cristales que actuaban como núcleo de cristalización obtenida mediante la inoculación de inulina tras la elaboración del producto. Esta técnica que se conoce como "sembrado" tuvo un efecto significativo tanto en las propiedades reológicas como en la microestructura de los postres. Para todas las concentraciones de inulina estudiadas, el sembrado favoreció una formación rápida de una gran cantidad de cristales de tamaño homogéneo que producía también un aumento de la viscosidad y elasticidad del producto. De esta forma, se comprobó que la técnica de sembrado resultó efectiva para obtener postres lácteos bajos en grasa, con un tamaño regular de partículas de inulina cuya abundancia y tamaño dependió de la concentración de inulina utilizada. 
Dado que la capacidad de cristalización de la inulina esta ligada a su tamaño molecular y a su concentración y con objeto de disminuir la formación de cristales que pudieran afectar a la calidad del producto, se decidió utilizar una mezcla de inulinas de cadena larga y de cadena corta para desarrollar un nuevo postre prebiótico, de bajo contenido en grasa. Primero se estudió el efecto de la variación de la concentración de la mezcla de inulinas, del azúcar y de aroma a limón en las propiedades reológicas, en las propiedades sensoriales y en la aceptabilidad del producto. El diseño experimental y el análisis se realizó de acuerdo al Método de Superficie de Respuesta. Las propiedades reológicas de los sistemas modelo de postres lácteos variaron significativamente con la composición. La consistencia y elasticidad de las muestras se incrementó con la concentración de inulina y en menor medida, con la de azúcar. Las diferencias en las características reológicas detectadas entre muestras dieron lugar a diferencias perceptibles en la consistencia de las mismas. Mediante la utilización de escalas diseñadas para medir el grado de adecuación de la intensidad de los atributos sensoriales (JAR) se determinó el grado de consistencia que los consumidores consideraban como el más adecuado para el producto. Los datos obtenidos de esta forma se relacionaron con los parámetros reológicos de comportamiento de flujo y viscoelasticidad. Se demostró que tanto el índice de consistencia como el módulo de elasticidad constituían buenos índices para predecir la adecuación de la consistencia de este tipo de postres lácteos y se establecieron los intervalos que para cada parámetro se correspondían con el nivel adecuado de consistencia. Este tipo de información es útil en las etapas preliminares de los procesos de desarrollo y reformulación de nuevos productos. Con ella se puede obtener información sobre la adecuación de la intensidad de los atributos sensoriales de una muestra con una medida instrumental de forma rápida y más económica que con una evaluación por consumidores. 
Finalmente, para optimizar la aceptabilidad del nuevo postre lácteo se estableció la relación entre las variaciones en la composición y la variación en la aceptabilidad. El nivel de agrado de los consumidores varió principalmente con la concentración de inulina y de azúcar y en menor medida con la de aroma a limón. De acuerdo al modelo se determinó para cada ingrediente el intervalo de concentraciones de máxima aceptabilidad (entre 4 y 6,5\% de inulina, entre 9 y $12 \%$ de azúcar y entre 25 y 95 ppm de aroma de limón). El conocimiento de los efectos de cada ingrediente y de las interacciones entre ellos en la aceptabilidad del producto, permite plantear modificaciones en la formulación que respondan a distintos intereses (nutricional o económico) y que mantengan una aceptabilidad óptima. La aceptabilidad del nuevo postre prebiótico elaborado con una formulación optimizada (5.5\% inulina, 10\% de azúcar y 60 ppm de aroma), se comparó con la de un postre de referencia seleccionado y elaborado previamente con azúcar, sin inulina y con el contenido en grasa habitual. La aceptación por los consumidores del nuevo postre no fue significativamente distinta a la del postre de referencia. Además de su carácter prebiótico, el nuevo postre era bajo en grasa y con menor contenido en azúcar y en aroma de limón.

\section{REFERENCIAS}

Ares, G., Giménez, A. \& Deliza, R. 2009. Influence of three non-sensory factors on consumer choice of functional yogurts over regular ones. Food Quality and Preference, 21: 361-367.

Cardello, A. V. (1994). Consumer expectations and their role in food acceptance. In H.J.H. MacFie \& D.M.H. Thomson (Eds.), Measurement of Food Preferences (pp. 253-297). London: Blackie Academic \& Professional. 
Monaco, R. Di, Cavella, S., and Marzo, S. (2004). The effect of expectations generated by brand name on the acceptability of dried semolina pasta. Food Quality and Preference, 15: 429-437

Varela, P., Ares, G., Giménez, A., \& Gámbaro, A. (2010). Influence of brand information on consumers' expectations and liking of powered drinks in central location tests. Food Quality and Preference, 21: 873-880.

Villegas, B. Carbonell, I. \& Costell, E. (2008). Effects of product information and consumer attitudes on responses to milk and soybean vanilla beverages. Journal of the Science of Food and Agriculture, 88: 24262434.

Urala, N., \& Lähteenmäki, L. (2007). Consumers' changing attitudes towards functional foods. Food Quality and Preference, 18: 1-12. 
CONCLUSIONES 

1. El uso del análisis conjunto (conjoint analysis) y de la técnica de escalamiento (laddering) permite investigar las opiniones y actitudes de los consumidores y establecer que características, intrínsecas o extrínsecas, de los alimentos son las más interesantes para cada grupo de personas. En el estudio de la respuesta de los consumidores uruguayos frente a los nuevos productos funcionales, ha permitido entender las diferentes reacciones y establecer los motivos individuales de cada elección.

2. Los consumidores uruguayos mostraron una buena predisposición al consumo de quesos bajos en grasa pero fueron reacios a aceptar otras alternativas orientadas a incrementar diferentes características saludables de este producto. Esta actitud estuvo originada por la creencia de que los quesos con las otras modificaciones de composición consideradas en este estudio, podrían tener una calidad sensorial deficiente y también, por la desconfianza sobre el beneficio real que podrían aportar a la salud.

3. La aceptación por los consumidores de diferentes marcas comerciales de queso bajo en grasa uruguayo (queso magro) no solo dependió de sus características sensoriales sino también de la confirmación o no de las expectativas generadas por la etiqueta.

4. El uso de las escalas para medir la opinión de los consumidores sobre la adecuación de la intensidad de los atributos sensoriales (Just about right scales) es una herramienta eficaz en el diseño de nuevos alimentos. Además, la información que proporciona puede ser útil para establecer o seleccionar índices químicos o instrumentales aplicables al posterior control de calidad del producto. 
5. La mezcla de inulinas de cadena corta y de cadena larga, utilizada como ingrediente en el desarrollo de nuevos alimentos prebióticos, aporta ventajas tecnológicas importantes en comparación con el uso de inulinas con un solo tamaño molecular. En esta tesis, dicha mezcla ha permitido desarrollar y optimizar la formulación de un nuevo postre lácteo prebiótico, bajo en grasa y con menor contenido en azúcar, sin disminuir su aceptabilidad respecto a la de un postre convencional, no prebiótico, y con el contenido en grasa y en azúcar habituales en este tipo de productos. 

